U.S. Department of the Interior

U.S. Geological Survey

\title{
Evaluation of Borehole Geophysical and Video Logs, at Butz Landfill Superfund Site, Jackson Township, Monroe County, Pennsylvania
}

by Dennis J. Low and Randall W. Conger

Water-Resources Investigations Report 01-4173 


\section{U.S. DEPARTMENT OF THE INTERIOR \\ GALE A. NORTON, Secretary}

\section{U.S. GEOLOGICAL SURVEY}

Charles G. Groat, Director

For additional information write to:

District Chief

U.S. Geological Survey

215 Limekiln Road

New Cumberland, Pennsylvania 17070-2424
Copies of this report may be purchased from:

U.S. Geological Survey

Branch of Information Services

Box 25286

Denver, Colorado 80225-0286 


\section{CONTENTS}

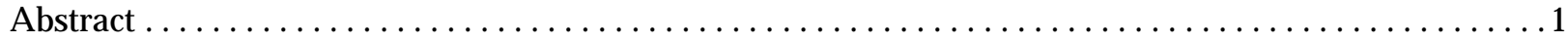

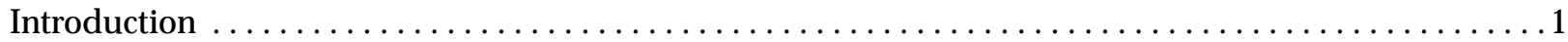

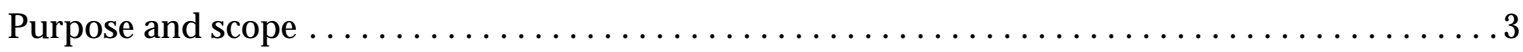

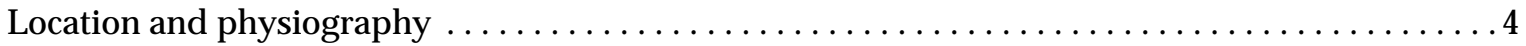

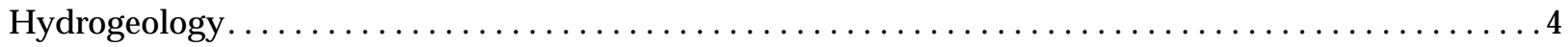

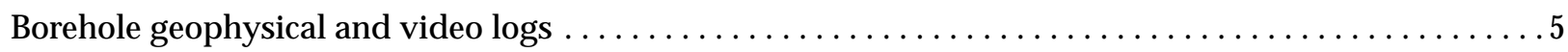

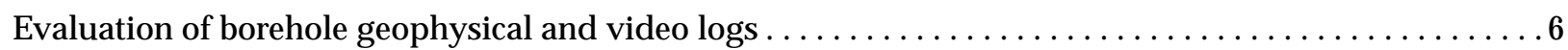

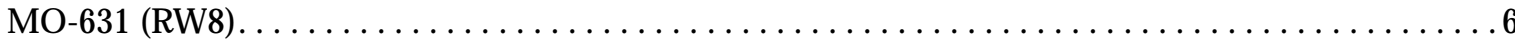

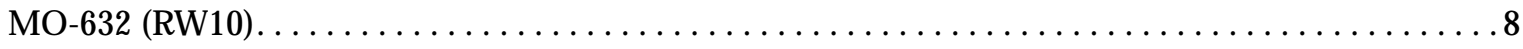

MO-633 (RW12) . . . . . . . . . . . . . . . . . . . . . . . . . . . . . . . . . . . 10

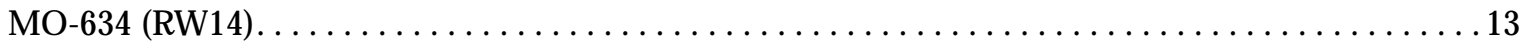

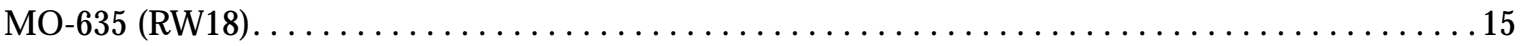

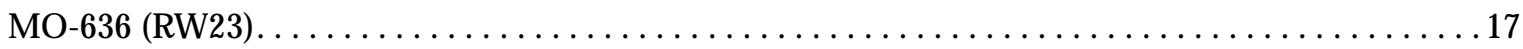

MO-637 (RW39) . . . . . . . . . . . . . . . . . . . . . . . . . . . . . . . . . . . . . 19

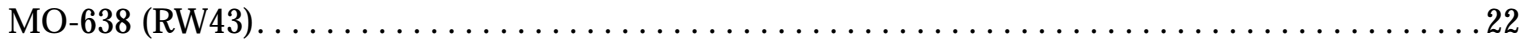

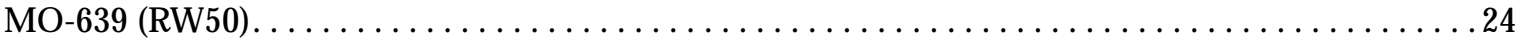

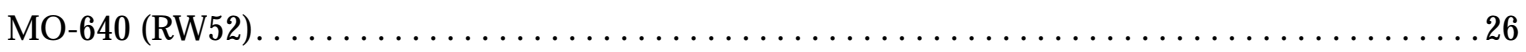

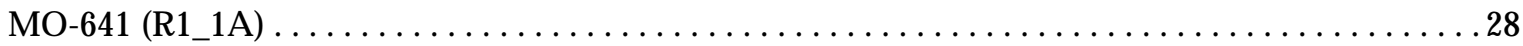

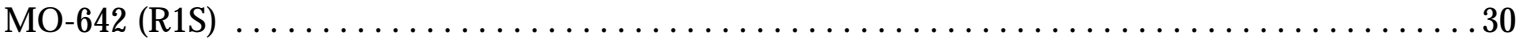

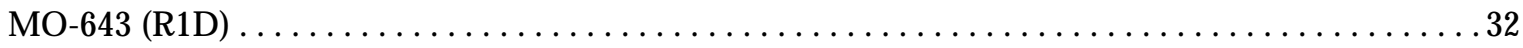

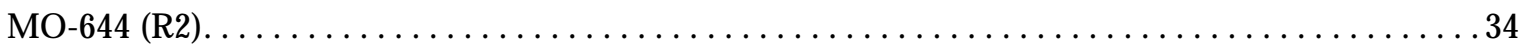

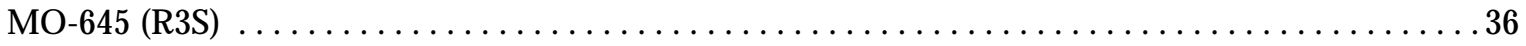

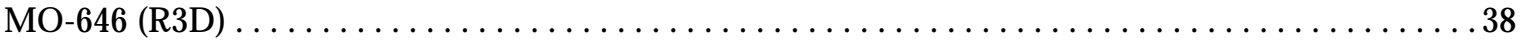

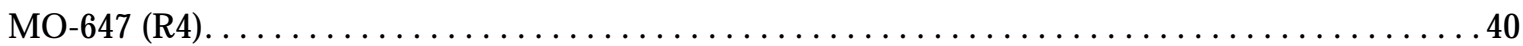

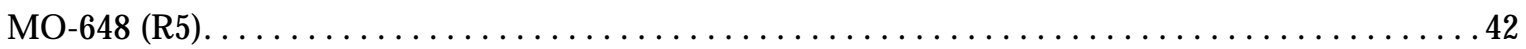

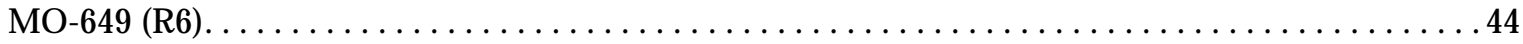

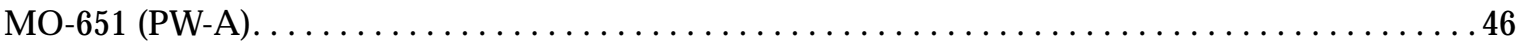

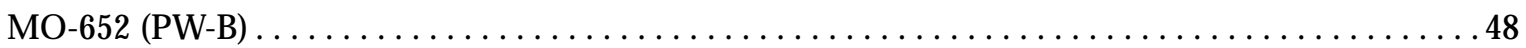

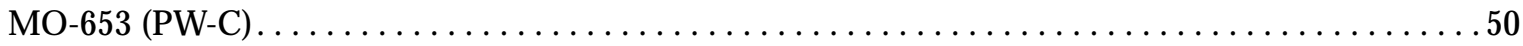

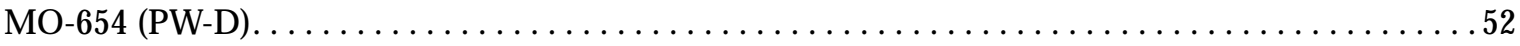

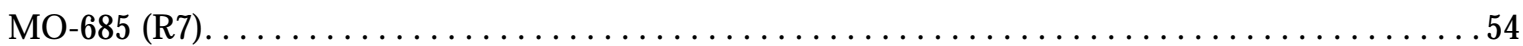

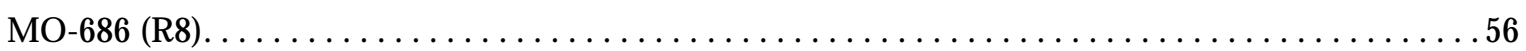

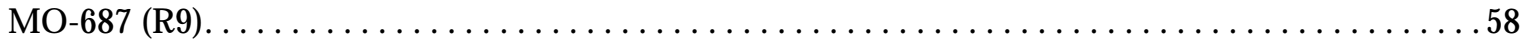

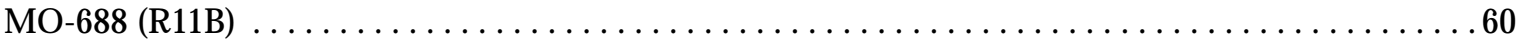

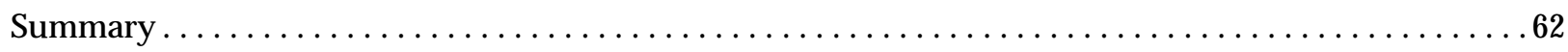

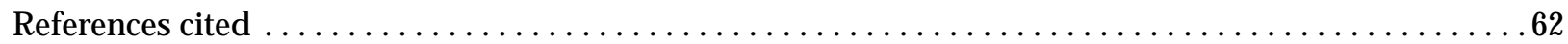




\section{ILLUSTRATIONS}

Figure 1. Locations of landfill and boreholes logged in and adjacent to the Butz Landfill Superfund Site, Jackson Township, Monroe County, Pennsylvania ........... 2

2-3. Graphs showing borehole geophysical logs and direction of borehole flow under nonpumping conditions within boreholes, Butz Landfill Superfund Site:

2. MO-631 (RW8), collected on April 3, $1996 \ldots \ldots \ldots \ldots \ldots \ldots \ldots \ldots \ldots$

3. MO-632 (RW10), collected on March 29, $1996 \ldots \ldots \ldots \ldots \ldots \ldots \ldots$

4. Graph showing borehole geophysical logs and direction of borehole flow under nonpumping and pumping conditions within MO-633 (RW12), collected

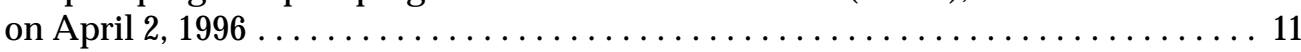

5-7. Graphs showing borehole geophysical logs and direction of borehole flow under nonpumping conditions within:

5. MO-634 (RW14), collected on April 4, $1996 \ldots \ldots \ldots \ldots \ldots \ldots \ldots \ldots \ldots \ldots \ldots \ldots \ldots \ldots$

6. MO-635 (RW18), collected on March 13, 1996 ...................... 16

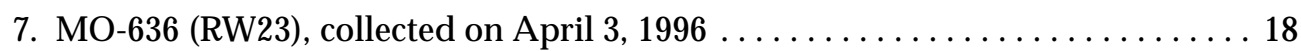

8. Graph showing borehole geophysical logs and direction of borehole flow under nonpumping and pumping conditions within MO-637 (RW39), collected on April 4, 1996 . ............................................ 20

9-10. Graphs showing borehole geophysical logs and direction of borehole flow under nonpumping conditions within:

9. MO-638 (RW43), collected on March 28, $1996 \ldots \ldots \ldots \ldots \ldots \ldots \ldots \ldots \ldots$

10. MO-639 (RW50), collected on April 3, 1996 . ........................ 25

11. MO-640 (RW52), collected on April 2, 1996 . . . . . . . . . . . . . . . . . . . 27

12. Graph showing borehole geophysical logs and direction of borehole flow under nonpumping and pumping conditions within MO-641 (R1_1A), collected on

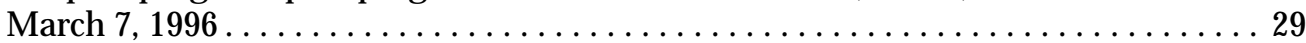

13. Graph showing borehole geophysical logs and direction of borehole flow under nonpumping conditions within MO-642 (R1S), collected on April 5, 1996 . . . . . . 31

14-17. Graphs showing borehole geophysical logs and direction of borehole flow under nonpumping and pumping conditions within:

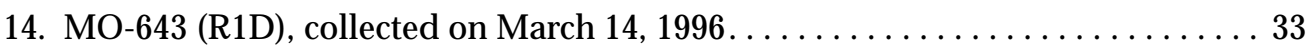

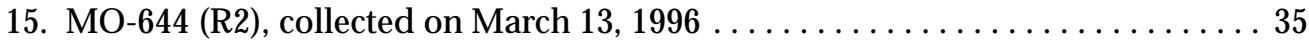

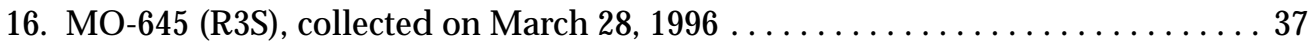

17. MO-646 (R3D), collected on March 6, 1996 . . . . . . . . . . . . . . . . . . . . . 39

18. Graph showing borehole geophysical logs and direction of borehole flow under nonpumping conditions within MO-647 (R4), collected on March 6, 1996 . . . . . . 41

19-24. Graphs showing borehole geophysical logs and direction of borehole flow under nonpumping and pumping conditions within:

19. MO-648 (R5), collected on February $28,1996 \ldots \ldots \ldots \ldots \ldots \ldots \ldots \ldots \ldots$

20. MO-649 (R6), collected on March 5, $1996 \ldots \ldots \ldots \ldots \ldots \ldots \ldots \ldots \ldots \ldots$

21. MO-651 (PW-A), collected on July $8,1996 \ldots \ldots \ldots \ldots \ldots \ldots \ldots \ldots \ldots$ 


\section{ILLUSTRATIONS-Continued}

Figures 19-24. Graphs showing borehole geophysical logs and direction of borehole flow under nonpumping and pumping conditions within-Continued:

22. MO-652 (PW-B), collected on July $9,1996 \ldots \ldots \ldots \ldots \ldots \ldots \ldots \ldots \ldots$

23. MO-653 (PW-C), collected on August 20, 1996 . . . . . . . . . . . . . . . . . . 51

24. MO-654 (PW-D), collected on July 1, $1996 \ldots \ldots \ldots \ldots \ldots \ldots \ldots \ldots \ldots \ldots \ldots \ldots \ldots$

25-28. Graphs showing borehole geophysical logs and direction of borehole flow under nonpumping conditions within:

25. MO-685 (R7), collected on November 6, 2000 . . . . . . . . . . . . . . . . 55

26. MO-686 (R8), collected on October $24,2000 \ldots \ldots \ldots \ldots \ldots \ldots \ldots \ldots \ldots \ldots$

27. MO-687 (R9), collected on November 6, 2000 . . . . . . . . . . . . . . . . . . . 59

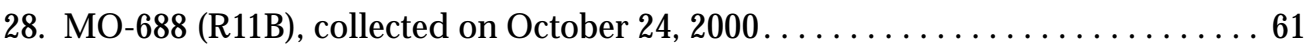

\section{TABLES}

Table 1. Boreholes logged at the Butz Landfill Superfund Site, Jackson Township,

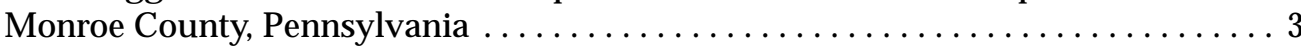

2-32. Summary of heatpulse-flowmeter measurements for boreholes at the Butz Landfill Superfund Site:

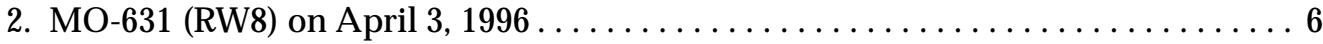

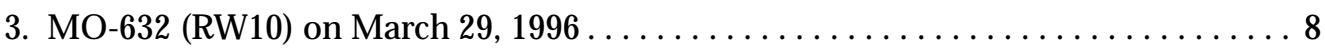

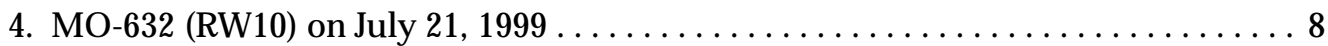

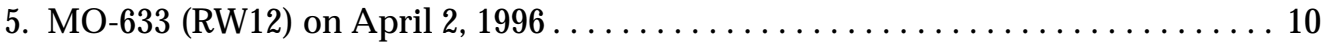

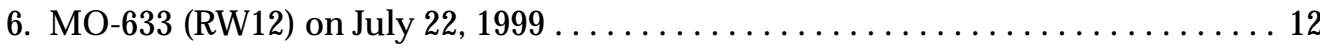

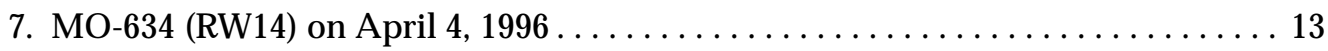

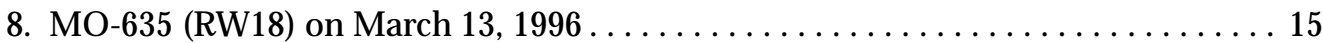

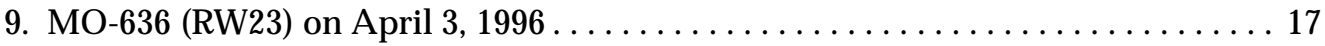

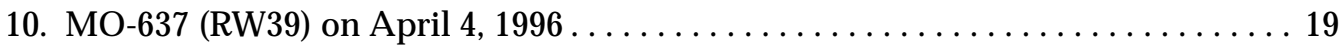

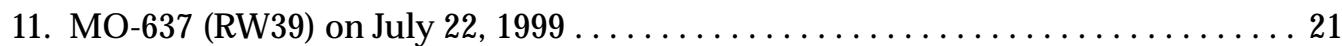

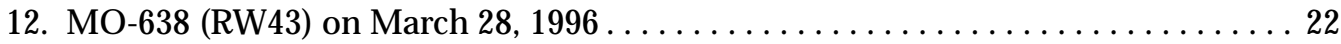

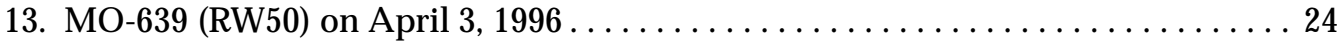

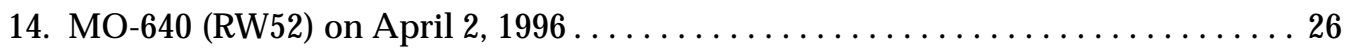

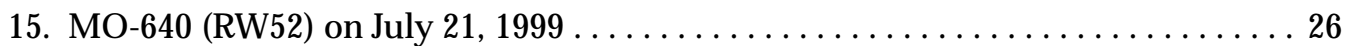

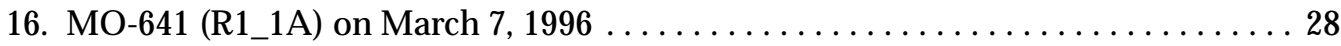

17. MO-642 (R1S) on April 5, 1996 ............................. 30

18. MO-643 (R1D) on March 14, 1996 . . . . . . . . . . . . . . . . . . . . . . . . . . . . 32

19. MO-644 (R2) on March 13, 1996................................. 34

20. MO-645 (R3S) on March 28, 1996 ............................... 36

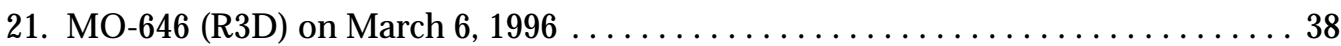




\section{TABLES-Continued}

Tables 2-32. Summary of heatpulse-flowmeter measurements for boreholes at the Butz Landfill Superfund Site-Continued:

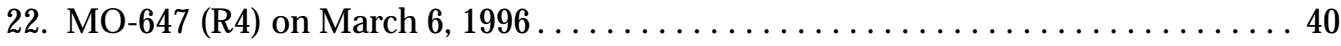

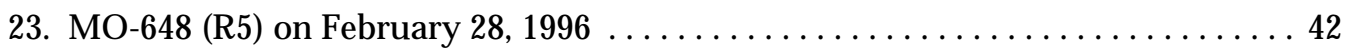

24. MO-649 (R6) on March 5, 1996............................. 44

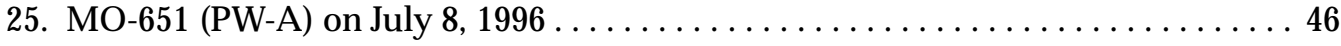

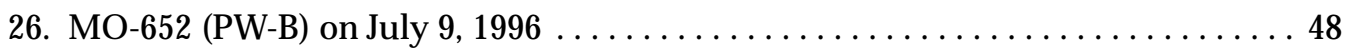

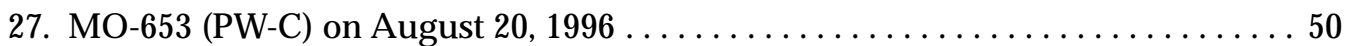

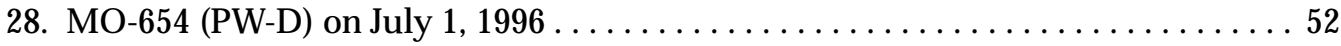

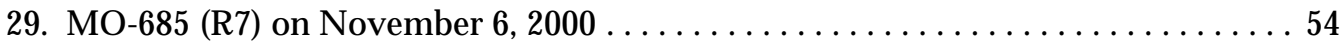

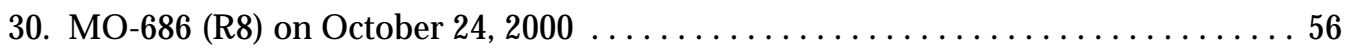

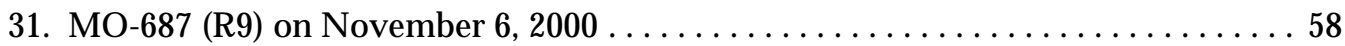

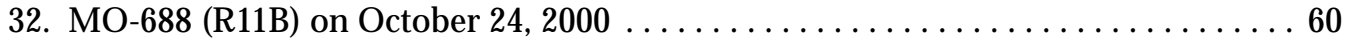

\section{CONVERSION FACTORS, ABBREVIATIONS, AND VERTICAL DATUM}

\begin{tabular}{|c|c|c|}
\hline \multirow[t]{2}{*}{ Multiply } & By & \\
\hline & \multicolumn{2}{|l|}{ Length } \\
\hline inch (in) & 2.54 & centimeter \\
\hline \multirow[t]{2}{*}{ foot $(\mathrm{ft})$} & 0.3048 & meter \\
\hline & Area & \\
\hline \multirow[t]{2}{*}{ acre } & 4,047 & square meter \\
\hline & Flow rate & \\
\hline gallon per minute (gal/min) & 0.06309 & liter per second \\
\hline degree Fahrenheit $\left({ }^{\circ} \mathrm{F}\right)$ & $\frac{\text { Temperature }}{{ }^{\circ} \mathrm{C}=5 / 9\left({ }^{\circ} \mathrm{F}-32\right)}$ & degree Celsius \\
\hline
\end{tabular}

Sea level: In this report, "sea level" refers to the National Geodetic Vertical Datum of 1929-a geodetic datum derived from a general adjustment of the first-order level nets of the United States and Canada, formerly called Sea Level Datum of 1929. 


\title{
Evaluation of Borehole Geophysical and Video Logs, at Butz Landfill Superfund Site, Jackson Township, Monroe County, Pennsylvania
}

\author{
by Dennis J. Low and Randall W. Conger
}

\begin{abstract}
Between February 1996 and November 2000, geophysical logging was conducted in 27 openborehole wells in and adjacent to the Butz Landfill Superfund Site, Jackson Township, Monroe County, Pa., to determine casing depth and depths of water-producing zones, water-receiving zones, and zones of vertical borehole flow. The wells range in depth from 57 to 319 feet below land surface. The geophysical logging determined the placement of well screens and packers, which allow monitoring and sampling of water-bearing zones in the fractured bedrock so that the horizontal and vertical distribution of contaminated ground water migrating from known sources could be determined. Geophysical logging included collection of caliper, natural-gamma, single-point-resistance, fluid-resistivity, fluid-temperature, and video logs. Caliper and video logs were used to locate fractures, joints, and weathered zones. Inflections on single-point-resistance, fluid-temperature, and fluid-resistivity logs indicated possible water-bearing fractures, and heatpulse-flowmeter measurements verified these locations. Natural-gamma logs provided information on stratigraphy.
\end{abstract}

\section{INTRODUCTION}

The Butz Landfill Superfund Site (Butz Landfill) covers approximately 13.4 acres; the landfill area and monitor wells are shown on the U.S. Geological Survey (USGS) Mount Pocono 7.5-minute topographic quadrangle map (fig. 1). The Butz Landfill was used as a municipal-waste dump from approximately 1963 until at least 1969; some landfill activities probably continued until 1984 (Bureau of Reclamation, 1994).

In early 1973, the Pennsylvania Department of Environmental Protection (PADEP) ordered the landfill closed. In 1986, PADEP conducted a site inspection and sampling program of domestic wells in close proximity to the site and detected volatile organic compounds (VOC's) in the ground water. A Remedial Investigation/Feasibility Study (RI/FS) was initiated by the U.S. Environmental Protection Agency (USEPA) and its consultants in December 1988 and completed in September 1991. The RI/FS identified trichloroethylene (TCE), 1,2-dichloroethene (1,2-DCE), and vinyl chloride (VC) as the principal contaminants. In June 1992, the Record of Decision (ROD) was signed stating that no remedial actions were necessary for surface water, sediments, or the landfill. The selected remedy for contaminated ground water was to design and install a well-extraction system that would reduce TCE concentrations to background levels prior to discharge to local surface waters. On the basis of the remedial actions in the ROD, USEPA requested the Bureau of Reclamation (BOR) to install a permanent water-supply system and design and install an extraction-well system for cleanup of contaminated ground water.

In 1996, BOR asked USGS to assist with hydrologic investigations for the Remedial Design (RD) study at the Butz Landfill. USGS involvement was directed toward identification of water-bearing zones in the contaminated fractured-bedrock aquifer to help ensure monitor wells were completed at appropriate depth horizons. This work is part of the support provided by USGS to USEPA on hydrogeologic investigations at Superfund sites in Pennsylvania. 


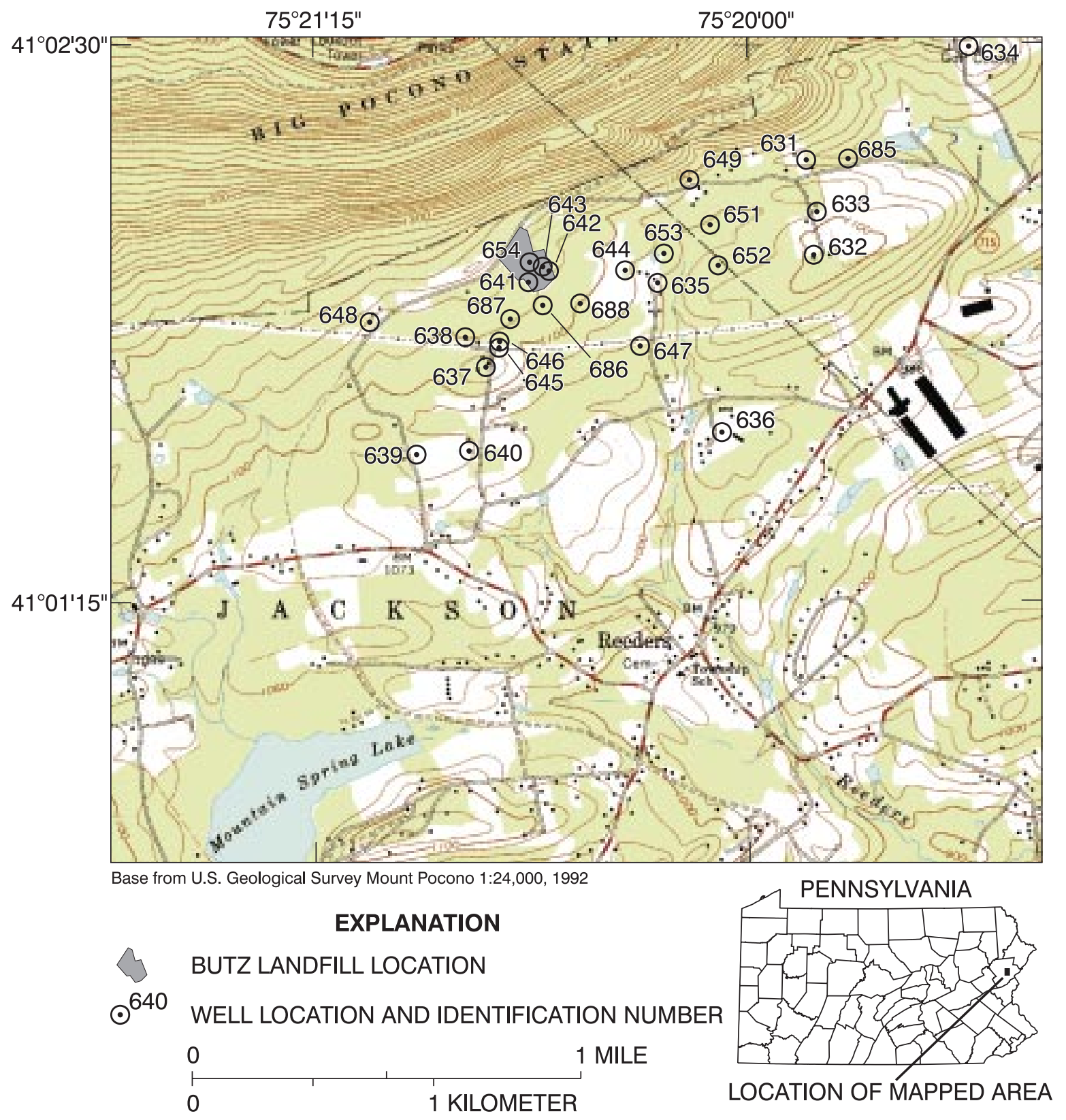

Figure 1. Locations of landfill and boreholes logged in and adjacent to the Butz Landfill Superfund Site, Jackson Township, Monroe County, Pennsylvania (prefix "MO" is omitted for visual clarity). 


\section{Purpose and Scope}

This report evaluates borehole geophysical and video logs collected by the USGS in 27 open boreholes in and adjacent to the Butz Landfill Superfund Site, Jackson Township, Monroe County, Pa., (table 1 and fig. 1) from February 28, 1996, to November 6, 2000. This report (1) identifies the location of subsurface fractures; (2) identifies, where possible, important water-bearing fractures; (3) identifies zones of potential borehole flow; and (4) describes the direction and rate of vertical borehole flow. These data provided hydrogeologic information in and adjacent to the Butz Landfill to select the most appropriate depth to screen and set permanent borehole packers for sampling discrete intervals in each borehole.

Table 1. Boreholes logged at the Butz Landfill Superfund Site, Jackson Township, Monroe County, Pennsylvania (B, borehole video; C, caliper log; G, natural-gamma; $R$, single-point resistance, F, fluid-resistivity log; $T$, fluidtemperature log; $\mathrm{V}$, heatpulse flowmeter)

\begin{tabular}{|c|c|c|c|c|c|c|}
\hline $\begin{array}{l}\text { U.S.Geological } \\
\text { Survey borehole- } \\
\text { identification } \\
\text { number }\end{array}$ & $\begin{array}{l}\text { Bureau of } \\
\text { Reclamation } \\
\text { borehole- } \\
\text { identification } \\
\text { number }\end{array}$ & Date logged & $\begin{array}{l}\text { Depth } \\
\text { logged } \\
\text { (feet) }\end{array}$ & $\begin{array}{c}\text { Depth to } \\
\text { water below } \\
\text { land surface } \\
\text { (feet) }\end{array}$ & $\begin{array}{l}\text { Length of } \\
\text { casing below } \\
\text { land surface } \\
\text { (feet) }\end{array}$ & $\begin{array}{c}\text { Geophysical logs } \\
\text { collected }\end{array}$ \\
\hline MO-631 & RW8 & 04/03/1996 & 118 & 1.38 & 28 & $\mathrm{C}, \mathrm{F}, \mathrm{T}, \mathrm{V}$ \\
\hline MO-632 & RW10 & $\begin{array}{l}03 / 29 / 1996 \\
07 / 21 / 1999\end{array}$ & 167 & $\begin{array}{l}27.56 \\
42.94\end{array}$ & 28 & $\begin{array}{l}\mathrm{C}, \mathrm{F}, \mathrm{T}, \mathrm{V} \\
\mathrm{B}, \mathrm{C}, \mathrm{F}, \mathrm{T}, \mathrm{V}\end{array}$ \\
\hline MO-633 & RW12 & $\begin{array}{l}04 / 02 / 1996 \\
07 / 22 / 1999\end{array}$ & 319 & $\begin{array}{l}35.55 \\
43.54\end{array}$ & 37 & $\begin{array}{l}\text { C, F, T, V } \\
\text { B, C, F, T, V }\end{array}$ \\
\hline MO-634 & RW14 & 04/04/1996 & 293.6 & 73.22 & 8 & $\mathrm{C}, \mathrm{F}, \mathrm{T}, \mathrm{V}$ \\
\hline MO-635 & RW18 & 03/13/1996 & 138 & 10.72 & 95 & $\mathrm{C}, \mathrm{F}, \mathrm{T}, \mathrm{V}$ \\
\hline MO-636 & RW23 & 04/03/1996 & 95 & 24.39 & 21 & $\mathrm{C}, \mathrm{F}, \mathrm{T}, \mathrm{V}$ \\
\hline MO-637 & RW39 & $\begin{array}{l}04 / 04 / 1996 \\
07 / 22 / 1999\end{array}$ & 221 & $\begin{array}{l}40.13 \\
44.40\end{array}$ & 59 & $\begin{array}{l}\mathrm{C}, \mathrm{F}, \mathrm{T}, \mathrm{V} \\
\mathrm{B}, \mathrm{C}, \mathrm{F}, \mathrm{T}, \mathrm{V}\end{array}$ \\
\hline MO-638 & RW43 & 03/28/1996 & 56 & 6.99 & 14 & $\mathrm{C}, \mathrm{F}, \mathrm{T}, \mathrm{V}$ \\
\hline MO-639 & RW50 & 04/03/1996 & 88 & 12.21 & 66 & $\mathrm{C}, \mathrm{F}, \mathrm{T}, \mathrm{V}$ \\
\hline MO-640 & RW52 & $\begin{array}{l}04 / 02 / 1996 \\
07 / 21 / 1999\end{array}$ & 122 & $\begin{array}{l}13.89 \\
19.26\end{array}$ & 50 & $\begin{array}{l}\text { C, F, T, V } \\
\text { B, C, F, T, V }\end{array}$ \\
\hline MO-641 & R1_1A & 03/07/1996 & 201 & 15.75 & 18 & $\mathrm{C}, \mathrm{F}, \mathrm{T}, \mathrm{V}$ \\
\hline MO-642 & R1S & 04/05/1996 & 98.7 & 4.07 & 25 & $\mathrm{C}, \mathrm{F}, \mathrm{T}, \mathrm{V}$ \\
\hline MO-643 & R1D & 03/14/1996 & 241 & 16.56 & 103 & $\mathrm{C}, \mathrm{F}, \mathrm{T}, \mathrm{V}$ \\
\hline MO-644 & $\mathrm{R} 2$ & 03/13/1996 & 132.5 & 7.12 & 19 & $\mathrm{C}, \mathrm{F}, \mathrm{T}, \mathrm{V}$ \\
\hline MO-645 & R3S & 03/28/1996 & 101 & 25.70 & 40 & $\mathrm{C}, \mathrm{F}, \mathrm{T}, \mathrm{V}$ \\
\hline MO-646 & R3D & 03/06/1996 & 239.5 & 44.29 & 104 & $\mathrm{C}, \mathrm{F}, \mathrm{T}, \mathrm{V}$ \\
\hline MO-647 & $\mathrm{R} 4$ & 03/06/1996 & 147 & 14.55 & 18 & $\mathrm{C}, \mathrm{F}, \mathrm{T}, \mathrm{V}$ \\
\hline MO-648 & R5 & 02/28/1996 & 240 & 5.32 & 19 & $\mathrm{C}, \mathrm{F}, \mathrm{T}, \mathrm{V}$ \\
\hline MO-649 & R6 & 03/05/1996 & 241 & 9.19 & 18 & $\mathrm{C}, \mathrm{F}, \mathrm{T}, \mathrm{V}$ \\
\hline MO-651 & PW-A & 07/08/1996 & 158.5 & 12.63 & 34 & $\mathrm{C}, \mathrm{G}, \mathrm{R}, \mathrm{F}, \mathrm{T}, \mathrm{V}$ \\
\hline MO-652 & PW-B & 07/09/1996 & 149 & 12.17 & 37 & $\mathrm{C}, \mathrm{G}, \mathrm{R}, \mathrm{F}, \mathrm{T}, \mathrm{V}$ \\
\hline MO-653 & PW-C & 08/20/1996 & 185.5 & 23.40 & 29 & $\mathrm{C}, \mathrm{G}, \mathrm{R}, \mathrm{F}, \mathrm{T}, \mathrm{V}$ \\
\hline MO-654 & PW-D & 07/01/1996 & 248 & 20.55 & 30 & $\mathrm{C}, \mathrm{G}, \mathrm{R}, \mathrm{F}, \mathrm{T}, \mathrm{V}$ \\
\hline MO-685 & R7 & $11 / 06 / 2000$ & 248 & 10.39 & 37 & $\mathrm{C}, \mathrm{G}, \mathrm{R}, \mathrm{F}, \mathrm{T}, \mathrm{V}$ \\
\hline MO-686 & $\mathrm{R} 8$ & $10 / 24 / 2000$ & 249 & 28.07 & 38 & $\mathrm{C}, \mathrm{G}, \mathrm{R}, \mathrm{F}, \mathrm{T}, \mathrm{V}$ \\
\hline MO-687 & R9 & $11 / 06 / 2000$ & 249 & 22.65 & 37 & $\mathrm{~B}, \mathrm{C}, \mathrm{G}, \mathrm{R}, \mathrm{F}, \mathrm{T}, \mathrm{V}$ \\
\hline MO-688 & R11B & $10 / 24 / 2000$ & 140.2 & 18.07 & 19 & $\mathrm{~B}, \mathrm{C}, \mathrm{G}, \mathrm{R}, \mathrm{F}, \mathrm{T}, \mathrm{V}$ \\
\hline
\end{tabular}


Caliper, fluid-resistivity, and fluid-temperature logs and heatpulse-flowmeter measurements were collected in all 27 wells. Natural-gamma and single-point-resistance logs were collected in 8 of the 27 wells. Borehole-video logs were run in 6 of the 27 boreholes (table 1). A cross-reference between USGS borehole-identification numbers and BOR borehole-identification numbers is presented in table 1.

\section{Location and Physiography}

The Butz Landfill is in the Glaciated Low Plateau Section of the Appalachian Plateaus Physiographic Province (Fenneman, 1938; Berg and others, 1989) and is on the southern flank of east-west trending Camelback Mountain. The topography of the area has been affected greatly by continental glaciation and is characterized by scattered mountains separated by rounded hills and valleys; altitudes range between 700 and 2,133 ft above sea level. Altitude on site averages about 1,140 ft above sea level (fig. 1). The region lacks well-developed drainage; many streams drain into small lakes, ponds, and swamps.

\section{HYDROGEOLOGY}

Butz Landfill and surrounding area are overlain by unconsolidated surficial deposits of the Woodfordian Ground Moraine (Berg and others, 1977). The surficial deposits consist mainly of till and nonstratified clay, silt, sand, pebbles, cobbles, and boulders. Seismic refraction surveys done at Butz Landfill indicates that the thickness of surficial deposits range from 25 to $40 \mathrm{ft}$; the thickness may be as great as $100 \mathrm{ft}$ in areas of local bedrock depressions.

Butz Landfill and surrounding area are underlain by sedimentary rocks of the Upper Devonian age Long Run Member of the Catskill Formation. The Long Run Member consists predominantly of alternating gray to grayish-red, crossbedded to planar-bedded sandstone and red to gray siltstone and shale, arranged in fining-upward fluvial cycles. The fluvial cycles vary from about 20 to $100 \mathrm{ft}$ in thickness (Berg and others, 1977). Butz Landfill lies stratigraphically within the upper cycle facies, which is dominated by siltstone but also contains shale and very fine sandstone. Estimated maximum thickness of the Long Run Member is 3,175 ft. The regional bedding trend strikes N. $65^{\circ} \mathrm{E}$. and dips from 5 to $15^{\circ}$ to the northwest.

Ground water at Butz Landfill originates from infiltration of local precipitation and discharges to local intermittent streams, pumping wells, and underlying bedrock aquifers. After infiltrating through void spaces in the glaciated surficial glacial deposits and weathered bedrock, ground water moves through vertical and horizontal fractures and joints in the sandstones and shales. The sandstone aquifers are enveloped by shale aquitards.

Three types of flow systems have been recognized in the bedrock aquifers of Monroe County-local, intermediate, and regional (Carswell and Lloyd, 1979). The local flow or shallow ground-water system moves through the glaciated surficial deposits and weathered bedrock. The intermediate and regional or deep ground-water system moves through fractures and joints of the more competent bedrock. Groundwater levels fluctuate with pumping and seasonal variations in recharge. Water from the shallow system may drain locally to the intermittent streams and also leak downward to a deeper ground-water-flow system. Wells constructed as open boreholes penetrate both systems, and water levels measured in these wells represent composite heads. Where differences in potentiometric head are present, water in the borehole flows from zones of higher head to zones of lower head. Ground water generally flows in a direction similar to the topographic gradient. However, the natural direction of flow can be altered by pumping. Pumping from deep zones may induce downward flow from shallow zones. 


\section{BOREHOLE GEOPHYSICAL AND VIDEO LOGS}

Geophysical logs provide information on location of fractures (caliper and video logs), waterproducing and water-receiving zones, intervals of vertical borehole flow (fluid-resistivity and fluidtemperature logs), quantification of borehole flow (heatpulse-flowmeter measurements), lithologic correlation (natural-gamma and single-point-resistance logs), and data on well construction (caliper and single-point-resistance logs).

Caliper logs provide a continuous record of average borehole diameter, which is related to fractures, lithology, and drilling technique. Caliper logs are used to identify fractures and possible water-producing and water-receiving zones and correct other geophysical logs for changes in borehole diameter. Correlation of caliper logs with fluid-resistivity and fluid-temperature logs is used to identify fractures, water-producing zones, water-receiving zones, and zones of vertical borehole flow.

The natural-gamma or gamma log measures the natural-gamma radiation (photons) emitted from rocks penetrated by the borehole. The most common sources of gamma radiation are uranium-238, thorium-232, their daughter elements, and potassium-40. These radioactive elements are concentrated in clays by adsorption, precipitation, and ion exchange. Fine-grained sediments, such as shale or siltstone, usually emit more gamma radiation than sandstone, limestone, or dolomite. Geophysical logging with a gamma probe can be conducted in the fluid-filled, dry, cased, or uncased parts of a borehole. However, casing does reduce the gamma response. The gamma log is used to correlate geologic units between wells or boreholes (Keys, 1990).

The single-point-resistance log records the electrical resistance of a formation between the probe in a water-filled borehole below casing and an electrical ground at land surface. Generally, electrical resistance increases with formation grain size and decreases with increasing borehole diameter, water-bearing fractures, and increasing dissolved-solids concentration of borehole water. The single-point-resistance log is used to correlate geology and lithology between wells or boreholes and may help identify formation water-bearing zones (Keys, 1990).

Fluid resistivity is the inverse of fluid conductivity. The fluid-resistivity log measures the electrical resistivity of the water column in the well. The fluid-resistivity probe measures the resistivity of borehole water between electrodes in the probe. Fluid-resistivity logs reflect changes in the dissolved-solids concentration of the well water. Fluid-resistivity logs are used to identify water-producing and waterreceiving zones and to determine intervals of vertical borehole flow. Water-producing and water-receiving zones usually are identified by distinct changes in resistivity. Intervals of vertical borehole flow are usually identified by a low-resistivity gradient between a water-producing and a water-receiving zone. Also, some types of contaminant plumes can be identified with fluid-resistivity logs.

Fluid-temperature logs provide a continuous record of the temperature of vertical variation in the water in a borehole. Temperature logs are used to identify water-producing and water-receiving zones and to determine zones of vertical borehole flow. Intervals of vertical borehole flow are characterized by little or no temperature gradient (Williams and Conger, 1990).

The direction and rate of borehole-water movement was determined by the use of a heatpulse flowmeter. The heatpulse flowmeter operates by heating a small volume of water between two sensitive thermistors (heat sensors). A measurement of direction and rate is computed when a peak temperature is recorded by one of the thermistors. The range of flow measurements is about 0.01 to $1.2 \mathrm{gal} / \mathrm{min}$ in a 2 - to 10-in.-diameter borehole (Conger, 1996).

Some heatpulse-flowmeter measurements may be affected by (1) poor seal integrity between the borehole and heatpulse flowmeter, and (2) contributions of water from storage within the borehole. If the seal between the borehole and flowmeter is not complete, some water can bypass the flowmeter, resulting in measurements of flow that are less than the actual rate. Although the heatpulse flowmeter is a calibrated probe, the data primarily are used as a relative indicator to identify water-producing or water-receiving zones. 
Borehole-video logging was conducted by lowering a waterproof camera down the borehole and recording the image on video tape. The depth indicated on the video log typically is within plus or minus $1.0 \mathrm{ft}$ of the geophysical logs because of some minor slippage of the television cable and is corrected by comparison with other geophysical logs.

\section{EVALUATION OF BOREHOLE GEOPHYSICAL AND VIDEO LOGS}

The locations of boreholes logged are shown on figure 1 . The reference measuring point for all geophysical logs and video logs is in feet below land surface. For each borehole, the date(s) logged, depth logged, water level at the time of logging, and list of logs run in each borehole are presented in table 1.

\section{MO-631 (RW8)}

Monitor well MO-631 was logged April 3, 1996. The caliper log shows the borehole is drilled to a depth of $118 \mathrm{ft}$ bls (below land surface) and is cased with 6-in.-diameter casing to $28 \mathrm{ft}$ bls (fig. 2). There is, however, $4 \mathrm{ft}$ of muck (soft mud and silt) from 118 to $122 \mathrm{ft}$ bls in the borehole. The caliper log shows major fractures at 40 and $115 \mathrm{ft}$ bls plus numerous minor fractures throughout the openhole interval. The fluidresistivity log shows numerous minor changes in slope that correlate closely with major and minor fractures on the caliper log, indicating possible lateral flow. The fluid-temperature log shows a change in slope at approximately $40 \mathrm{ft}$ bls that correlates to a major fracture shown on the caliper log. Under nonpumping conditions, the heatpulse flowmeter measured upward borehole flow at 25 and $36 \mathrm{ft}$ bls and downward flow at 45, 65, 84, 97, and $110 \mathrm{ft}$ bls (table 2). The geophysical logs and the heatpulse-flowmeter data indicate water enters the borehole through the major fracture at $40 \mathrm{ft}$ bls, moves upward and downward, and exits the borehole through a minor fracture at $34 \mathrm{ft}$ bls, breaks in casing at about 10, 15, and $21 \mathrm{ft} \mathrm{bls}$, and the fracture at $115 \mathrm{ft}$ bls. The fracture at $40 \mathrm{ft}$ bls produces about $2 \mathrm{gal} / \mathrm{min}$ of water under nonpumping conditions.

Table 2. Summary of heatpulse-flowmeter measurements for borehole MO-631 (RW8) on April 3, 1996, at the Butz Landfill Superfund Site, Jackson Township, Monroe County, Pennsylvania

\begin{tabular}{ccc}
\hline $\begin{array}{c}\text { Depth } \\
\text { (feet below land } \\
\text { surface) }\end{array}$ & $\begin{array}{c}\text { Flow rate under } \\
\text { nonpumping conditions } \\
\text { (gallons per minute) }\end{array}$ & $\begin{array}{c}\text { Flow direction under } \\
\text { nonpumping conditions }\end{array}$ \\
\hline 25 & 0.19 & Up \\
36 & .55 & Up \\
45 & 1.49 & Down \\
65 & 1.47 & Down \\
84 & 1.50 & Down \\
97 & 1.49 & Down \\
110 & 1.49 & Down \\
\hline
\end{tabular}




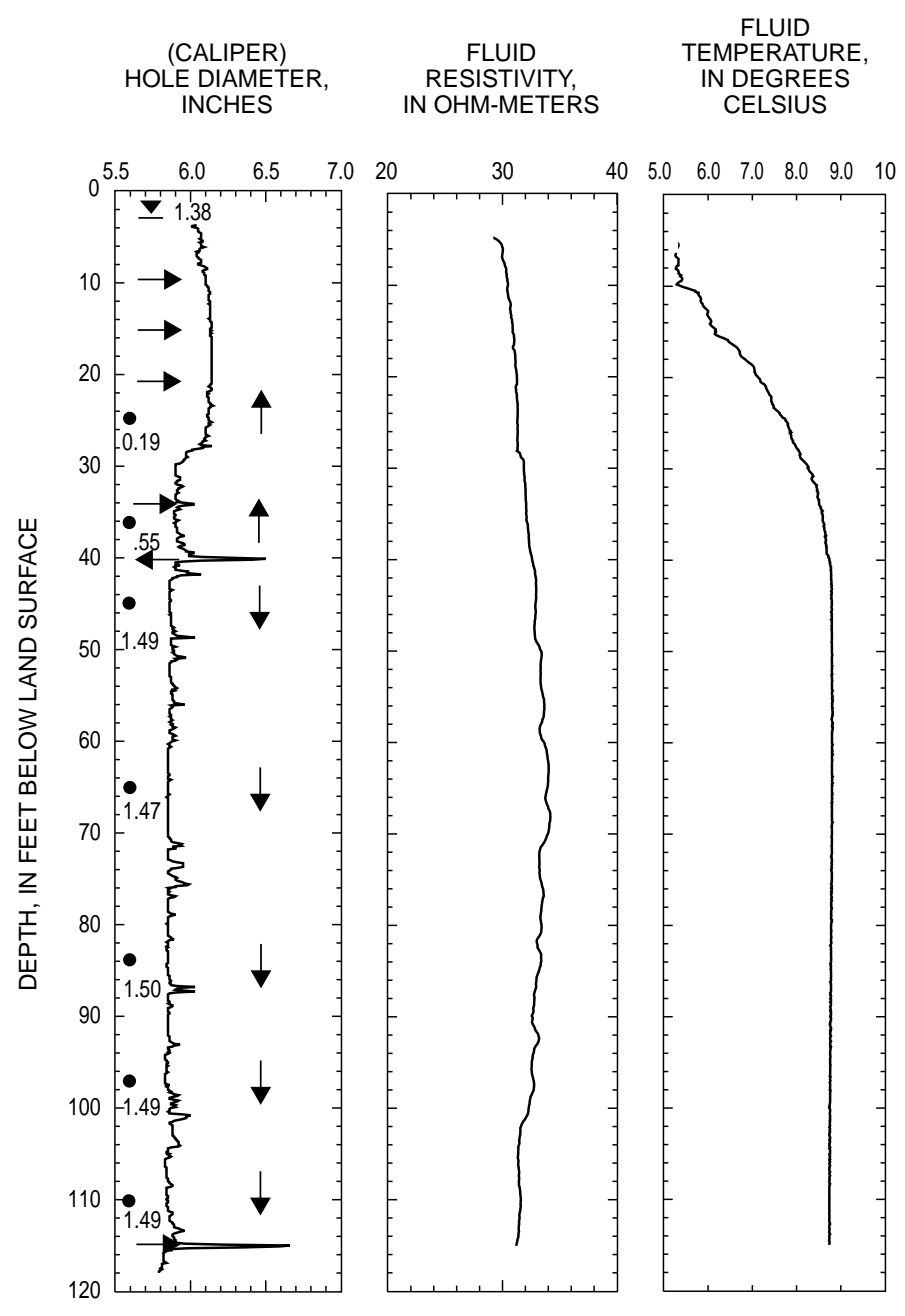

\section{EXPLANATION}

- 1.38 STATIC WATER LEVEL-Measured in well at the time of geophysical logging

- 0.19 BOREHOLE-FLOW MEASUREMENT UNDER NONPUMPING CONDITIONSCircle at depth of flow measurement. Number is measured flow in gallon per minute.

T1 DIRECTION OF BOREHOLE FLOW UNDER NONPUMPING CONDITIONS

$-\quad$ KNOWN (OR INFERRED) WATER-PRODUCING ZONE UNDER NONPUMPING CONDITIONS

KNOWN (OR INFERRED) WATER-RECEIVING ZONE UNDER NONPUMPING CONDITIONS

Figure 2. Borehole geophysical logs and direction of borehole flow under nonpumping conditions within MO-631 (RW8), collected on April 3, 1996, Butz Landfill Superfund Site, Jackson Township, Monroe County, Pennsylvania. 


\section{MO-632 (RW10)}

Monitor well MO-632 was logged March 29, 1996 (fig. 3), and on July 21, 1999. The caliper log shows the borehole is drilled to a depth of $167 \mathrm{ft}$ and is cased with 6-in.-diameter casing to $28 \mathrm{ft}$ bls. The caliper $\log$ shows major fractures at 47 to 49,72 to 73 , and 82 to $86 \mathrm{ft}$ bls plus numerous minor fractures throughout the openhole interval. The fluid-resistivity log shows major changes in slope at 72 and 114 to $132 \mathrm{ft}$ bls plus minor deflections at 33, 40, 48, 54, 60, 87, 95, and $104 \mathrm{ft}$ bls. The decrease in slope of the fluidresistivity $\log$ from 114 to $132 \mathrm{ft}$ bls probably is a product of change in water chemistry (increase in total dissolved solids) as a result of the absence of borehole flow. The fluid-temperature log shows minor changes in slope at 33, 40, and $87 \mathrm{ft}$ bls that correlate with fractures on the caliper log. Under nonpumping conditions, the heatpulse flowmeter measured downward flow at 44, 67, and $77 \mathrm{ft}$ bls, and no flow at 36 , 90 , and $98 \mathrm{ft}$ bls (table 3). This suite of borehole geophysical logs indicates, under nonpumping conditions, water enters the borehole through the fractures at 38 to 41,48 , and possibly $63 \mathrm{ft}$ bls and moves downward; a small quantity exits the borehole through the fractures at $73 \mathrm{ft}$ bls and 80 to $85 \mathrm{ft}$ bls.

Table 3. Summary of heatpulse-flowmeter measurements for borehole MO-632 (RW10) on March 29, 1996, at the Butz Landfill Superfund Site, Jackson Township, Monroe County, Pennsylvania $[-$, not determined]

\begin{tabular}{ccc}
\hline $\begin{array}{c}\text { Depth } \\
\text { (feet below land } \\
\text { surface) }\end{array}$ & $\begin{array}{c}\text { Flow rate under } \\
\text { nonpumping conditions } \\
\text { (gallons per minute) }\end{array}$ & $\begin{array}{c}\text { Flow direction under } \\
\text { nonpumping conditions }\end{array}$ \\
\hline 36 & No flow & - \\
44 & 0.35 & Down \\
67 & 1.20 & Down \\
77 & .90 & Down \\
90 & No flow & - \\
98 & No flow & - \\
\hline
\end{tabular}

The caliper log collected on July 21, 1999, is similar to that collected on March 29, 1996. The fluidresistivity log shows changes in slope at 53,55, 58, 71, 84, 95, and 102 to $104 \mathrm{ft}$ bls that correlate closely to fractures on the caliper log. Under nonpumping conditions, the heatpulse-flowmeter measurements indicated possible downward flow at $68 \mathrm{ft}$ bls, upward flow at $78 \mathrm{ft} \mathrm{bls}$, and no flow at 99, 120, and $146 \mathrm{ft}$ bls (table 4). The decrease in slope of the fluid-resistivity log from 116 to $132 \mathrm{ft}$ bls probably is a product of change in water chemistry (increase in total dissolved solids) as a result of the absence of borehole flow. The suite of borehole geophysical logs and heatpulse-flowmeter data indicate, under nonpumping conditions, the fractures at 61 and 81 to $86 \mathrm{ft}$ bls are water-producing zones, and the fracture at 73 to $75 \mathrm{ft}$ bls is a water-receiving zone.

Table 4. Summary of heatpulse-flowmeter measurements for borehole MO-632 (RW10) on July 21, 1999, at the Butz Landfill Superfund Site, Jackson Township, Monroe County, Pennsylvania

$[-$, not determined $]$

\begin{tabular}{ccccc}
\hline $\begin{array}{c}\text { Depth } \\
\text { (feet below land } \\
\text { surface) }\end{array}$ & $\begin{array}{c}\text { Flow rate under } \\
\text { nonpumping conditions } \\
\text { (gallon per minute) }\end{array}$ & $\begin{array}{c}\text { Flow direction under } \\
\text { nonpumping conditions }\end{array}$ & $\begin{array}{c}\text { Flow rate under } \\
\text { pumping conditions } \\
\text { (gallon per minute) }\end{array}$ & $\begin{array}{c}\text { Flow direction under } \\
\text { pumping conditions }\end{array}$ \\
\hline 68 & - & Down (?) & 0.57 & Up \\
78 & 0.05 & Up & .36 & No flow \\
99 & No flow & - & No flow & - \\
120 & No flow & - & No flow & - \\
146 & No flow & - & & - \\
\hline
\end{tabular}




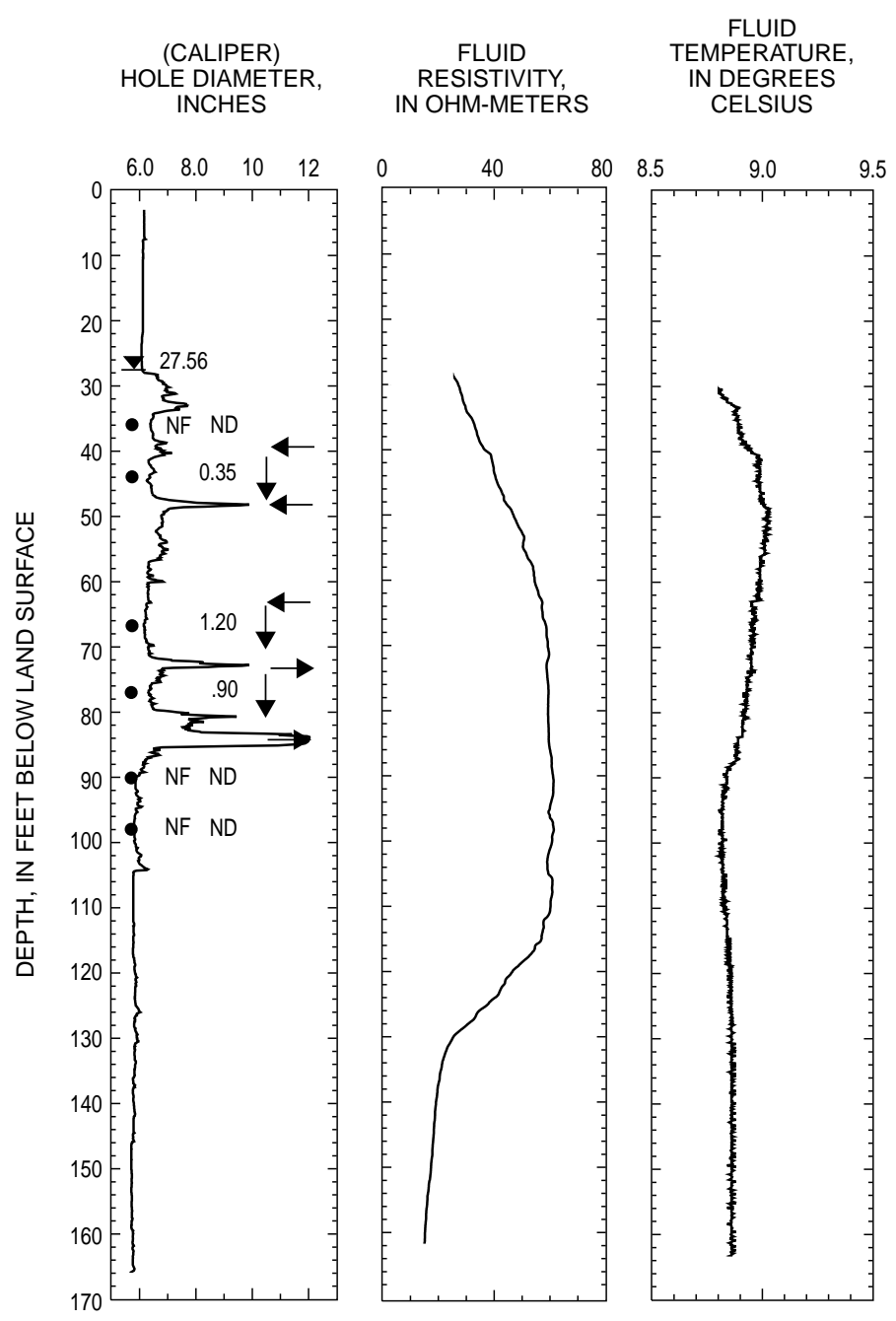

\section{EXPLANATION}

₹ 27.56 STATIC WATER LEVEL-Measured in well at the time of geophysical logging

- 0.35 BOREHOLE-FLOW MEASUREMENT UNDER NONPUMPING CONDITIONS-Circle at depth of flow measurement. Number is measured flow in gallon per minute.

$\downarrow$ DIRECTION OF BOREHOLE FLOW UNDER NONPUMPING CONDITIONS

$\longleftarrow \quad$ KNOWN (OR INFERRED) WATER-PRODUCING ZONE UNDER NONPUMPING CONDITIONS

$\rightarrow \quad$ KNOWN (OR INFERRED) WATER-RECEIVING ZONE UNDER NONPUMPING CONDITIONS

NF NO FLOW

ND NOT DETERMINED

Figure 3. Borehole geophysical logs and direction of borehole flow under nonpumping conditions within MO-632 (RW10), collected on March 29, 1996, Butz Landfill Superfund Site, Jackson Township, Monroe County, Pennsylvania. 
No borehole flow was observed on the video log under nonpumping conditions. The video log does show, however, the borehole is extensively fractured from a depth of about 34 to $88 \mathrm{ft}$ bls; fracturing generally is absent from a depth of about $106 \mathrm{ft}$ bls to the bottom of the borehole. Most of the fractures appear to be low-angle with secondary mineralization of the fractures very common at a depth of about $86 \mathrm{ft}$ bls.

A submersible pump was placed at $60 \mathrm{ft}$ bls, and the borehole was pumped at a rate of approximately $1 \mathrm{gal} / \mathrm{min}$. The water level in the borehole declined $0.21 \mathrm{ft}$ after 42 minutes of pumping. Under pumping conditions, the heatpulse flowmeter measured upward flow at 68 and $78 \mathrm{ft}$ bls and no flow at 99, 120, and $146 \mathrm{ft}$ bls. The suite of geophysical logs and heatpulse-flowmeter data indicate, under pumping conditions, water enters the borehole through the fractures at 73 to 75 and 81 to $86 \mathrm{ft}$ bls, moves upward, and exits the borehole through the fracture at $49 \mathrm{ft}$ bls (table 4).

\section{MO-633 (RW12)}

Monitor well MO-633 was logged April 2, 1996, and July 22, 1999. The caliper log shows the borehole is drilled to a depth of $319 \mathrm{ft}$ and is cased with 6-in.-diameter casing to $37 \mathrm{ft}$ bls (fig. 4). The caliper $\log$ shows major fractures at 47 to 49,76 to $78,95,156$, and $190 \mathrm{ft}$ bls plus numerous minor fractures throughout the openhole interval. The fluid-resistivity log shows changes in slope at 49, 64, and 70 to $78 \mathrm{ft}$ bls that correlate to fractures on the caliper log. The fluid-temperature log shows a minor change in slope at $65 \mathrm{ft}$ bls and a constant gradient change of about $0.2^{\circ} \mathrm{C}$ per $100 \mathrm{ft}$ of openhole interval from 95 to $319 \mathrm{ft}$ bls. Under nonpumping conditions, the heatpulse flowmeter measured downward borehole flow at $86 \mathrm{ft}$ bls and no flow at 42, 58, 68, 100, 110, 142, 160, and $200 \mathrm{ft}$ bls (table 5). The suite of borehole geophysical logs and heatpulse-flowmeter data indicate that under nonpumping conditions water enters the borehole through the fractures at 70 to $78 \mathrm{ft}$ bls, moves downward, and exits the borehole through the large fracture at $95 \mathrm{ft}$ bls.

Table 5. Summary of heatpulse-flowmeter measurements for borehole MO-633 (RW12) on April 2, 1996, at the Butz Landfill Superfund Site, Jackson Township, Monroe County, Pennsylvania

$[-$, not determined]

\begin{tabular}{|c|c|c|c|c|}
\hline $\begin{array}{c}\text { Depth } \\
\text { (feet below land } \\
\text { surface) }\end{array}$ & $\begin{array}{c}\text { Flow rate under } \\
\text { nonpumping conditions } \\
\text { (gallon per minute) }\end{array}$ & $\begin{array}{l}\text { Flow direction under } \\
\text { nonpumping conditions }\end{array}$ & $\begin{array}{l}\text { Flow rate under } \\
\text { pumping } \\
\text { conditions } \\
\text { (gallon per minute) }\end{array}$ & $\begin{array}{l}\text { Flow direction under } \\
\text { pumping } \\
\text { conditions }\end{array}$ \\
\hline 42 & No flow & - & - & - \\
\hline 58 & No flow & - & - & - \\
\hline 68 & No flow & - & - & - \\
\hline 86 & 0.11 & Down & 0.59 & Up \\
\hline 100 & No flow & - & .47 & Up \\
\hline 110 & No flow & - & .35 & Up \\
\hline 142 & No flow & - & .33 & Up \\
\hline 160 & No flow & - & .22 & Up \\
\hline 174 & - & - & .17 & Up \\
\hline 194 & - & - & No flow & - \\
\hline 200 & No flow & - & - & - \\
\hline
\end{tabular}




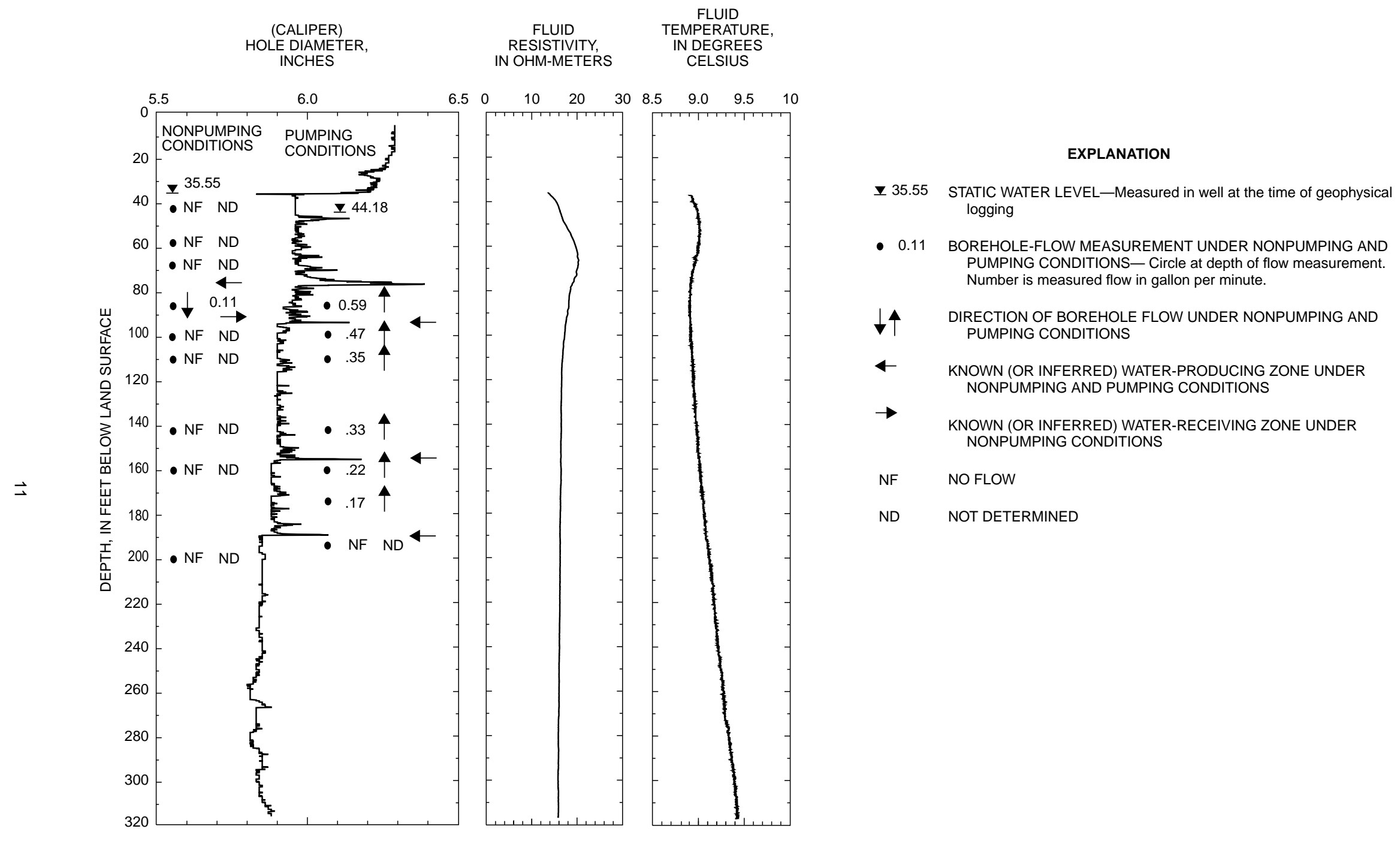

Figure 4. Borehole geophysical logs and direction of borehole flow under nonpumping and pumping conditions within MO-633 (RW12), collected on April 2, 1996, Butz Landfill Superfund Site, Jackson Township, Monroe County, Pennsylvania. 
A submersible pump was placed at $70 \mathrm{ft}$ bls, and the borehole was pumped at a rate less than $0.5 \mathrm{gal} / \mathrm{min}$. The water level in the borehole declined $10.44 \mathrm{ft}$ after 1 hour and 21 minutes of pumping before stabilizing. Under pumping conditions, the heatpulse flowmeter measured upward borehole flow at $86,100,110,142,160$, and $174 \mathrm{ft}$ bls and no flow at $194 \mathrm{ft}$ bls (table 5). The suite of borehole geophysical logs and heatpulse-flowmeter data indicate, under pumping conditions, water enters the borehole through the fractures at 94,156, and $190 \mathrm{ft}$ bls and moves upward.

The caliper log collected on July 22,1999, is similar to that collected on April 2, 1996. The fluidresistivity log shows a change in slope at 71 and $78 \mathrm{ft}$ bls that correlates to fractures on the caliper log. The fluid-temperature log shows a constant temperature gradient increase of about $0.2^{\circ} \mathrm{C}$ per $100 \mathrm{ft}$ of openhole interval from 95 to $310 \mathrm{ft}$ bls. Under nonpumping conditions, the heatpulse-flowmeter measurements indicated no flow at 44, 74, 84, 148, 184, 250, and $290 \mathrm{ft}$ bls (table 6). This result differs slightly from the data collected on April 2, 1996, in that downward flow of 0.11 gal $/ \mathrm{min}$ was measured at a depth of $86 \mathrm{ft}$ bls. Apparently, under less dry conditions, the fracture at 76 to $78 \mathrm{ft}$ bls is a water-producing zone, and the fracture at $94 \mathrm{ft}$ bls is a water-receiving zone.

No borehole flow was observed on the video log under nonpumping conditions. The video log does show, however, most fractures appear to be low-angle and are more common in the upper $154 \mathrm{ft}$ of the borehole.

A submersible pump was placed at $65 \mathrm{ft}$ bls, and the borehole was pumped at a rate that ranged from about 0.1 to $1.0 \mathrm{gal} / \mathrm{min}$. The water level in the borehole declined $6.00 \mathrm{ft}$ after 1 hour and 13 minutes of pumping. Under pumping conditions, the heatpulse flowmeter measured upward borehole flow at 74, 84, 100, 120, 150, and $184 \mathrm{ft}$ bls and no flow at 200, 220 and $250 \mathrm{ft}$ bls (table 6). The suite of borehole geophysical logs and heatpulse-flowmeter data indicate, under pumping conditions, the fracture at $190 \mathrm{ft}$ bls is the major water-producing zone.

Table 6. Summary of heatpulse-flowmeter measurements for borehole MO-633 (RW12) on July 22, 1999, at the Butz Landfill Superfund Site, Jackson Township, Monroe County, Pennsylvania

[-, not determined]

\begin{tabular}{|c|c|c|c|c|}
\hline $\begin{array}{c}\text { Depth } \\
\text { (feet below land } \\
\text { surface) }\end{array}$ & $\begin{array}{c}\text { Flow rate under } \\
\text { nonpumping conditions } \\
\text { (gallons per minute) }\end{array}$ & $\begin{array}{l}\text { Flow direction under } \\
\text { nonpumping conditions }\end{array}$ & $\begin{array}{l}\text { Flow rate under } \\
\text { pumping conditions } \\
\text { (gallon per minute) }\end{array}$ & $\begin{array}{l}\text { Flow direction under } \\
\text { pumping conditions }\end{array}$ \\
\hline 44 & No flow & - & - & - \\
\hline 74 & No flow & - & 0.12 & Up \\
\hline 84 & No flow & - & .13 & Up \\
\hline 100 & - & - & .14 & Up \\
\hline 120 & - & - & .13 & $\mathrm{Up}$ \\
\hline 148 & No flow & - & - & - \\
\hline 150 & - & - & .12 & Up \\
\hline 184 & No flow & - & .07 & Up \\
\hline 200 & - & - & No flow & - \\
\hline 220 & - & - & No flow & - \\
\hline 250 & No flow & - & No flow & - \\
\hline 290 & No flow & - & - & - \\
\hline
\end{tabular}




\section{MO-634 (RW14)}

Monitor well MO-634 was logged April 4, 1996. The caliper log shows the borehole is drilled to a depth of $293.6 \mathrm{ft}$ bls and is cased with 6-in.-diameter casing to $8 \mathrm{ft}$ bls (fig. 5). The caliper log shows major fractures at 66 to 69 and $123 \mathrm{ft}$ bls plus numerous minor fractures throughout the openhole interval. The fluid-resistivity log shows minor changes in slope at 124, 224, 248, 253, 255, and $277 \mathrm{ft}$ bls that correlate with fractures shown on the caliper log. The fluid-temperature log shows changes in slope at 124 and $248 \mathrm{ft}$ bls that correlate with fractures shown on the caliper log. Under nonpumping conditions, the heatpulse flowmeter measured downward borehole flow at 80, 90, 110, 141, 180, and $230 \mathrm{ft}$ bls and no flow at $260 \mathrm{ft}$ bls (table 7). The suite of geophysical logs and the heatpulse-flowmeter data indicate water enters the borehole through the fractures at 66 to 69 and $123 \mathrm{ft}$ bls and moves downward. Most water exits the borehole through the small fracture at $248 \mathrm{ft}$ bls. Additional, but smaller amounts of water exit the borehole through minor fractures at approximately 94 and $224 \mathrm{ft}$ bls.

Table 7. Summary of heatpulse-flowmeter measurements for borehole MO-634 (RW14) on April 4, 1996, at the Butz Landfill Superfund Site, Jackson Township, Monroe County, Pennsylvania

$[-$, not determined]

\begin{tabular}{ccc}
\hline $\begin{array}{c}\text { Depth } \\
\text { (feet below land } \\
\text { surface) }\end{array}$ & $\begin{array}{c}\text { Flow rate under } \\
\text { nonpumping conditions } \\
\text { (gallon per minute) }\end{array}$ & $\begin{array}{c}\text { Flow direction under } \\
\text { nonpumping conditions }\end{array}$ \\
\hline 80 & 0.74 & Down \\
90 & .75 & Down \\
110 & .58 & Down \\
141 & .99 & Down \\
180 & 1.05 & Down \\
230 & .91 & Down \\
260 & No flow & - \\
\hline
\end{tabular}




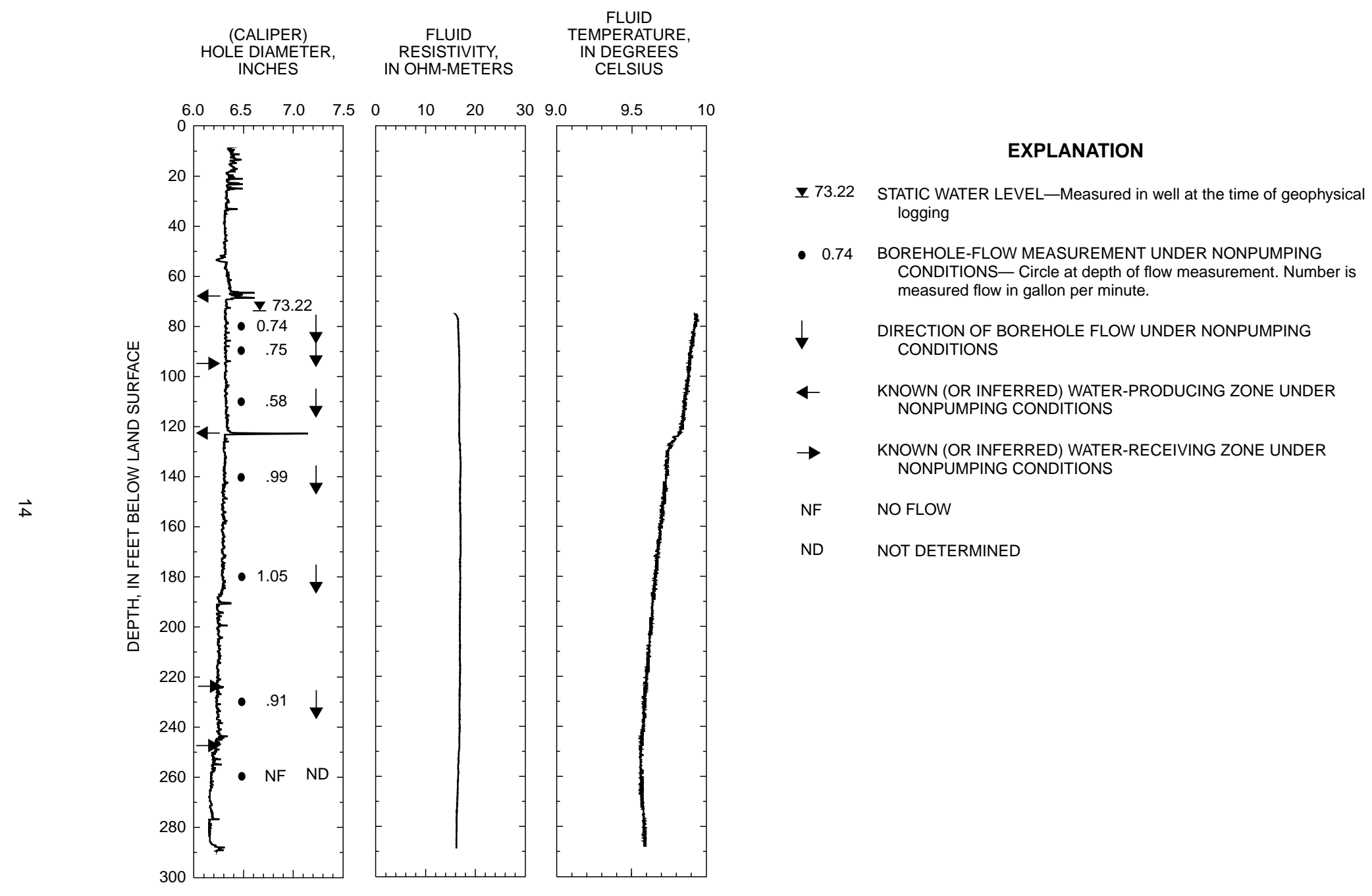

Figure 5. Borehole geophysical logs and direction of borehole flow under nonpumping conditions within MO-634 (RW14), collected on April 4, 1996, Butz Landfill Superfund Site, Jackson Township, Monroe County, Pennsylvania. 


\section{MO-635 (RW18)}

Monitor well MO-635 was logged March 13, 1996. The caliper log shows the borehole is drilled to a depth of $138 \mathrm{ft}$ bls and is cased with 6-in.-diameter casing to $95 \mathrm{ft}$ bls (fig. 6). The caliper log shows numerous small fractures throughout the openhole interval and a break in casing at $16 \mathrm{ft}$ bls. The fluidresistivity log shows a change in slope at approximately $110 \mathrm{ft}$ bls that correlates to a fracture on the caliper log. Under nonpumping conditions, the heatpulse flowmeter measured upward borehole flow at 25, 110, and $122 \mathrm{ft}$ bls (table 8). The large variation in flow measured at the lower two fractures indicate this well is affected by pumping, probably from domestic wells at the adjacent houses. The suite of geophysical logs and heatpulse-flowmeter data indicate water enters the borehole through fractures near the bottom of the borehole (below $122 \mathrm{ft}$ bls), moves upward, and exits the borehole through a break in the casing at $16 \mathrm{ft}$ bls and possibly at $28 \mathrm{ft}$ bls.

Table 8. Summary of heatpulse-flowmeter measurements for borehole MO-635 (RW18) on March 13, 1996, at the Butz Landfill Superfund Site, Jackson Township, Monroe County, Pennsylvania

\begin{tabular}{ccc}
\hline $\begin{array}{c}\text { Depth } \\
\text { feet below land } \\
\text { surface) }\end{array}$ & $\begin{array}{c}\text { Flow rate under } \\
\text { nonpumping conditions } \\
\text { (gallon per minute) }\end{array}$ & $\begin{array}{c}\text { Flow direction under } \\
\text { nonpumping conditions }\end{array}$ \\
\hline 25 & 0.27 & $\mathrm{Up}$ \\
110 & 0.00 to 0.35 & $\mathrm{Up}$ \\
122 & .00 to .35 & $\mathrm{Up}$ \\
\hline
\end{tabular}




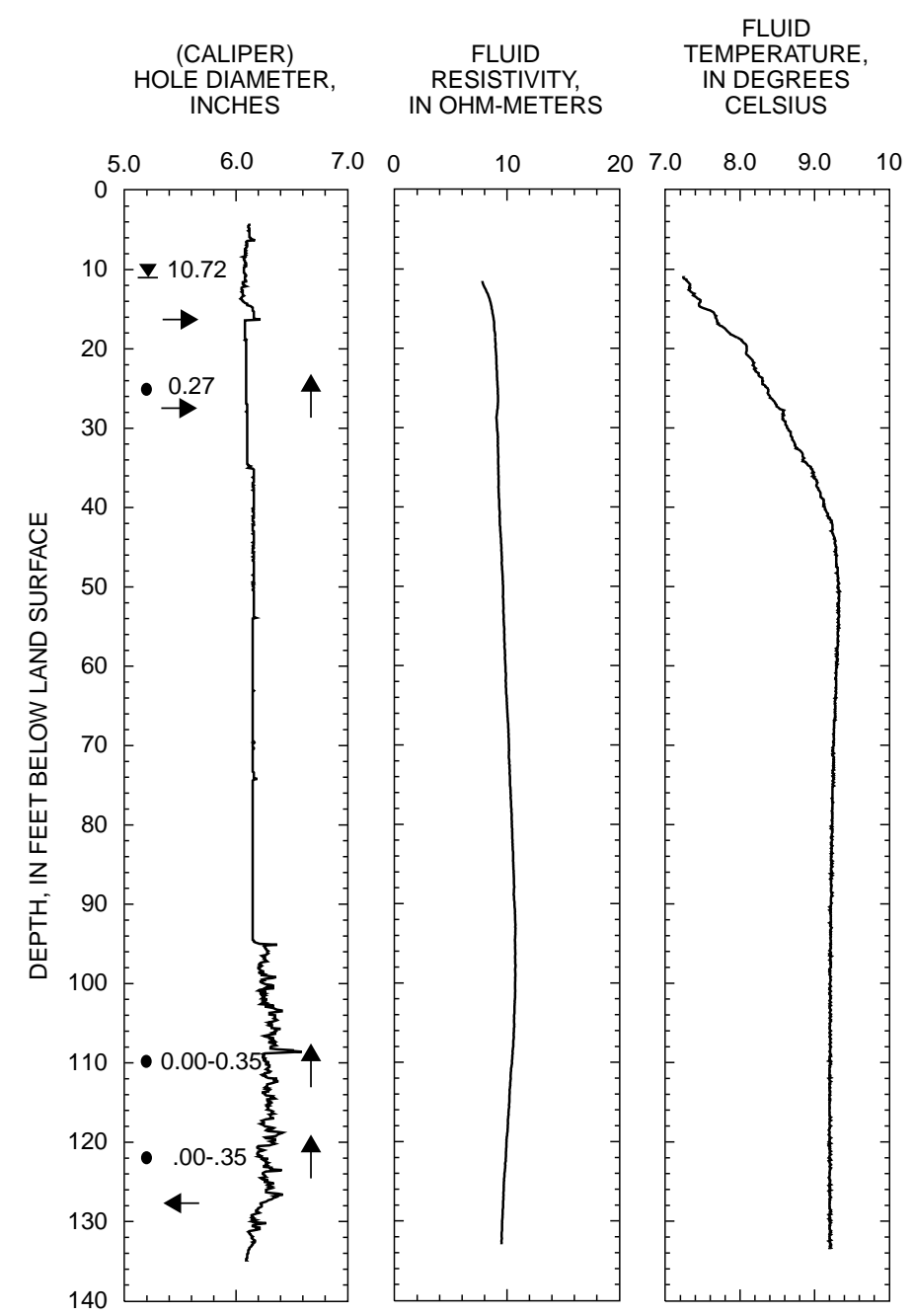

\section{EXPLANATION}

₹ 10.72 STATIC WATER LEVEL-Measured in well at the time of geophysical logging

- 0.27 BOREHOLE-FLOW MEASUREMENT UNDER NONPUMPING CONDITIONS- Circle at depth of flow measurement. Number is measured flow in gallon per minute.

A DIRECTION OF BOREHOLE FLOW UNDER NONPUMPING CONDITIONS

$\leftarrow \quad$ KNOWN (OR INFERRED) WATER-PRODUCING ZONE UNDER NONPUMPING CONDITIONS

$\rightarrow \quad$ KNOWN (OR INFERRED) WATER-RECEIVING ZONE UNDER NONPUMPING CONDITIONS

Figure 6. Borehole geophysical logs and direction of borehole flow under nonpumping conditions within MO-635 (RW18), collected on March 13, 1996, Butz Landfill Superfund Site, Jackson Township, Monroe County, Pennsylvania. 


\section{MO-636 (RW23)}

Monitor well MO-636 was logged April 3, 1996. The caliper log shows the borehole is drilled to a depth of $95 \mathrm{ft}$ bls and is cased with 6-in.-diameter casing to $21 \mathrm{ft}$ bls (fig. 7). The caliper log shows numerous fractures throughout the openhole interval. The fluid-resistivity log shows changes in slope from 40 to $56 \mathrm{ft}$ bls. The fluid-temperature log shows minor changes in slope at 40 and $44 \mathrm{ft} \mathrm{bls}$. These changes in slope in the fluid-resistivity and fluid-temperature logs may be caused by lateral borehole flow. Under nonpumping conditions, the heatpulse flowmeter measured downward borehole flow at 60, 74, and $88 \mathrm{ft}$ bls and no vertical flow at 35 and $48 \mathrm{ft}$ bls (table 9). The suite of geophysical logs and heatpulseflowmeter data indicate water enters the borehole through the fractures at approximately $53 \mathrm{ft}$ bls and moves downward. Minor amounts of water exit the borehole through fractures at 62 to 72,77 , and $82 \mathrm{ft}$ bls; the greatest amount of water leaves the borehole through fractures at 90 to $94 \mathrm{ft}$ bls.

Table 9. Summary of heatpulse-flowmeter measurements for borehole MO-636 (RW23) on April 3, 1996, at the Butz Landfill Superfund Site, Jackson Township, Monroe County, Pennsylvania

$[-$, not determined]

\begin{tabular}{ccc}
\hline $\begin{array}{c}\text { Depth } \\
\text { (feet below land } \\
\text { surface) }\end{array}$ & $\begin{array}{c}\text { Flow rate under } \\
\text { nonpumping conditions } \\
\text { (gallons per minute) }\end{array}$ & $\begin{array}{c}\text { Flow direction under } \\
\text { nonpumping conditions }\end{array}$ \\
\hline 35 & No flow & - \\
48 & Lateral flow & - \\
60 & 1.05 & Down \\
74 & .96 & Down \\
88 & .81 & Down \\
\hline
\end{tabular}




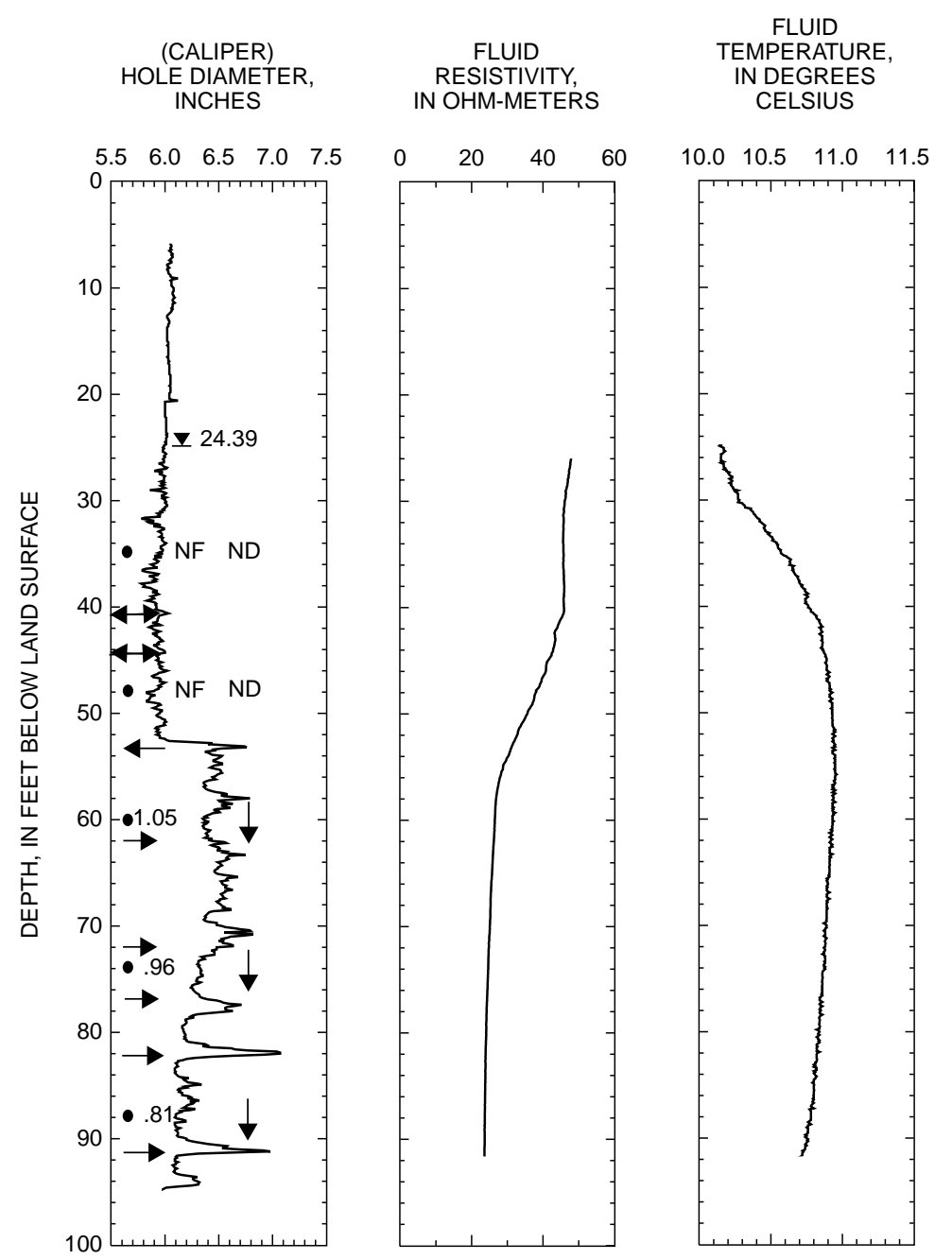

\section{EXPLANATION}

7 24.39 STATIC WATER LEVEL-Measured in well at the time of geophysical logging

- 1.05 BOREHOLE-FLOW MEASUREMENT UNDER NONPUMPING CONDITIONS - Circle at depth of flow measurement. Number is measured flow in gallons per minute.

DIRECTION OF BOREHOLE FLOW UNDER NONPUMPING CONDITIONS

$4 \quad$ KNOWN (OR INFERRED) WATER-PRODUCING ZONE UNDER NONPUMPING CONDITIONS

$\rightarrow \quad$ KNOWN (OR INFERRED) WATER-RECEIVING ZONE UNDER NONPUMPING CONDITIONS

$\leftrightarrow \quad$ LATERAL FLOW (INFERRED)

NF NO FLOW

ND NOT DETERMINED

Figure 7. Borehole geophysical logs and direction of borehole flow under nonpumping conditions within MO-636 (RW23), collected on April 3, 1996, Butz Landfill Superfund Site, Jackson Township, Monroe County, Pennsylvania. 


\section{MO-637 (RW39)}

Monitor well MO-637 was logged April 4, 1996, and July 22, 1999. The caliper log shows the borehole is drilled to a depth of $221 \mathrm{ft}$ and is cased with 6-in.-diameter casing to $59 \mathrm{ft}$ bls (fig. 8). The caliper $\log$ shows major fractures at 69 to 71 and 149 to $150 \mathrm{ft}$ bls plus numerous minor fractures throughout the openhole interval. The caliper log also shows the driller changed bit size at $150 \mathrm{ft}$ bls. The fluid-resistivity and fluid-temperature logs show a major change in slope at $72 \mathrm{ft}$ bls. The fluid-resistivity log also shows several smaller slope changes at 82, 95, 108, 150,159,184, and $195 \mathrm{ft}$ bls that correlate with fractures shown on the caliper log; these small changes in the slope of the fluid-resistivity log indicate possible lateral flow. Under nonpumping conditions, the heatpulse flowmeter measured variable downward borehole flow at 77 and $100 \mathrm{ft}$ bls and no flow at 65, 116, 132, and $155 \mathrm{ft}$ bls (table 10). The suite of borehole geophysical logs and heatpulse-flowmeter data indicate, under nonpumping conditions, water enters the borehole through the fracture at 69 to $71 \mathrm{ft} \mathrm{bls,} \mathrm{moves} \mathrm{downward,} \mathrm{and} \mathrm{exits} \mathrm{the} \mathrm{borehole} \mathrm{through} \mathrm{minor} \mathrm{fractures} \mathrm{from} 82$ to $108 \mathrm{ft}$ bls. The variable flow rates measured by the heatpulse flowmeter indicate nearby transient pumpage.

Table 10. Summary of heatpulse-flowmeter measurements for borehole MO-637 (RW39) on April 4, 1996, at the Butz Landfill Superfund Site, Jackson Township, Monroe County, Pennsylvania

[-, not determined]

\begin{tabular}{|c|c|c|c|c|}
\hline $\begin{array}{l}\text { Depth } \\
\text { (feet below land } \\
\text { surface) }\end{array}$ & $\begin{array}{c}\text { Flow rate under } \\
\text { nonpumping conditions } \\
\text { (gallons per minute) }\end{array}$ & $\begin{array}{l}\text { Flow direction under } \\
\text { nonpumping conditions }\end{array}$ & $\begin{array}{l}\text { Flow rate under } \\
\text { pumping conditions } \\
\text { (gallons per minute) }\end{array}$ & $\begin{array}{l}\text { Flow direction under } \\
\text { pumping conditions }\end{array}$ \\
\hline 60 & - & - & No flow & - \\
\hline 65 & No flow & - & No flow & - \\
\hline 77 & 1.00 to 1.45 & Down & No flow & - \\
\hline 100 & .42 to .98 & Down & - & - \\
\hline 116 & No flow & - & - & - \\
\hline 132 & No flow & - & - & - \\
\hline 155 & No flow & - & - & - \\
\hline
\end{tabular}

A submersible pump was placed at $55 \mathrm{ft}$ bls, and the borehole was pumped at approximately $3 \mathrm{gal} / \mathrm{min}$. The water level in the borehole declined $8.79 \mathrm{ft}$ after 45 minutes of pumping before beginning to stabilize. Under pumping conditions, the heatpulse flowmeter measured no borehole flow at 60,65 , and $77 \mathrm{ft}$ bls (table 10). The suite of geophysical logs and heatpulse-flowmeter data indicate, under pumping conditions, additional water is available to the borehole through a fracture above $60 \mathrm{ft}$ bls, probably at the bottom of the casing. 


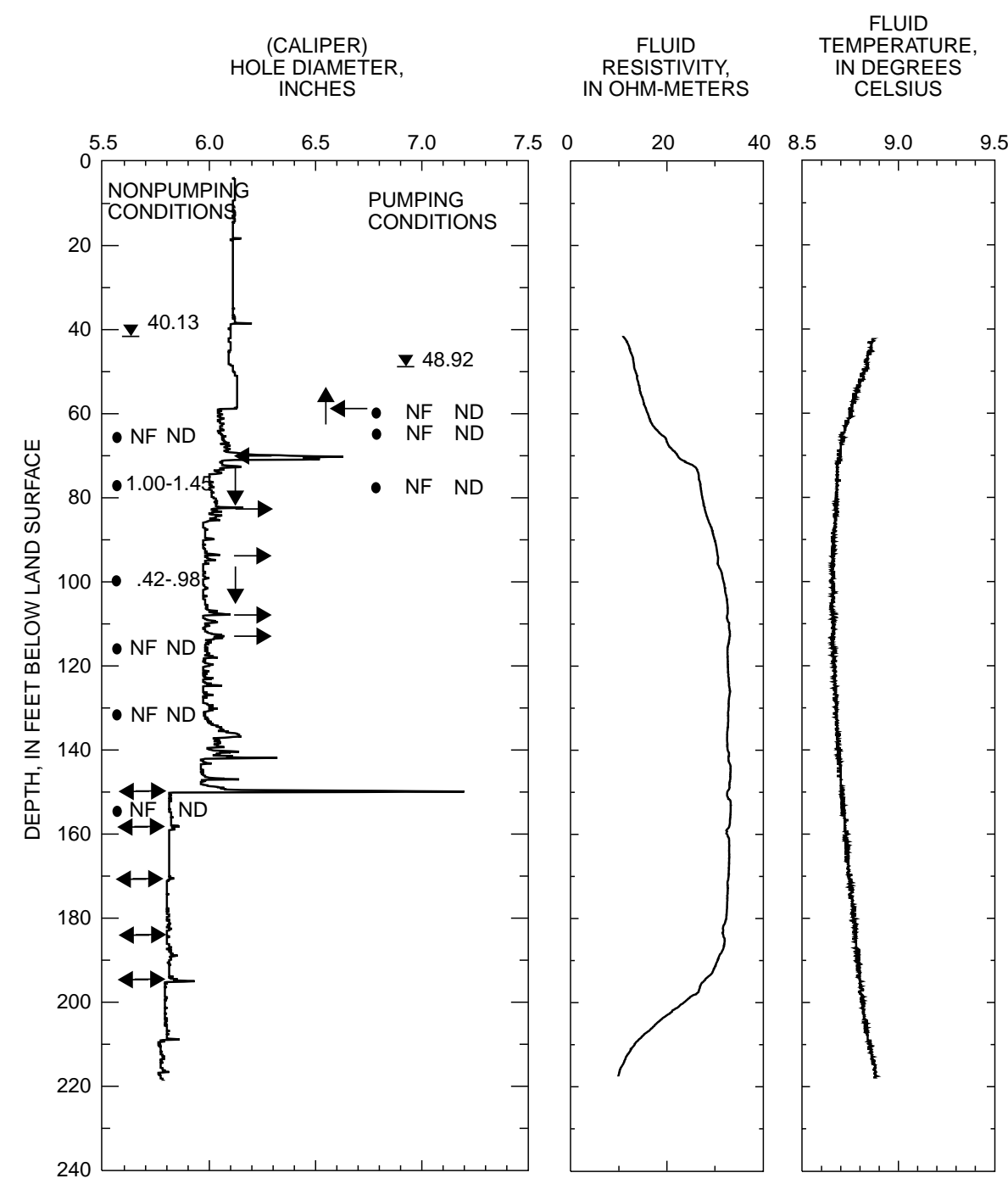

\section{EXPLANATION}

70.13 STATIC WATER LEVEL-Measured in well at the time of geophysical logging

- 1.45 BOREHOLE-FLOW MEASUREMENT UNDER NONPUMPING AND PUMPING CONDITIONS - Circle at depth of flow measurement. Number is measured flow in gallons per minute.

14 DIRECTION OF BOREHOLE FLOW UNDER NONPUMPING AND PUMPING CONDITIONS

$4 \quad$ KNOWN (OR INFERRED) WATER-PRODUCING ZONE UNDER NONPUMPING AND PUMPING CONDITIONS

$\rightarrow \quad$ KNOWN (OR INFERRED) WATER-RECEIVING ZONE UNDER NONPUMPING CONDITIONS

$\leftrightarrow \quad$ LATERAL FLOW (INFERRED)

NF NO FLOW

ND NOT DETERMINED

Figure 8. Borehole geophysical logs and direction of borehole flow under nonpumping and pumping conditions within MO-637 (RW39), collected on April 4, 1996, Butz Landfill Superfund Site, Jackson Township, Monroe County, Pennsylvania. 
The caliper log collected on July 22, 1999, is similar to that collected on April 4, 1996. The fluid resistivity $\log$ shows several minor deflections at $55,59,82,95,108,113$ to 121,136 to $142,150,159,171,182$, and $189 \mathrm{ft}$ bls. The temperature log shows abrupt changes in slope from 109 to 121 and $137 \mathrm{ft}$ bls that correlate to a series of minor fractures identified on the caliper log. Under nonpumping conditions, the heatpulse-flowmeter measurements indicated turbulent flow at $65 \mathrm{ft}$ bls, downward flow at 78, 100, 122, 145 , and $164 \mathrm{ft} \mathrm{bls,} \mathrm{and} \mathrm{no} \mathrm{flow} \mathrm{at} 202 \mathrm{ft}$ bls (table 11). The suite of borehole geophysical logs and heatpulse-flowmeter data indicate, under nonpumping conditions, most water enters the borehole from the major fracture at 70 to $72 \mathrm{ft}$ bls. The remaining fractures appear to be water-receiving zones as vertical borehole flow decreases with increasing depth.

Table 11. Summary of heatpulse-flowmeter measurements for borehole MO-637 (RW39) on July 22, 1999, at the Butz Landfill Superfund Site, Jackson Township, Monroe County, Pennsylvania

\begin{tabular}{ccccc} 
[-, not determined] & & & \\
\hline $\begin{array}{c}\text { Depth } \\
\text { (feet below land } \\
\text { surface) }\end{array}$ & $\begin{array}{c}\text { Flow rate under } \\
\text { nonpumping conditions } \\
\text { (gallon per minute) }\end{array}$ & $\begin{array}{c}\text { Flow direction under } \\
\text { nonpumping conditions }\end{array}$ & $\begin{array}{c}\text { Flow rate under } \\
\text { pumping conditions } \\
\text { (gallons per minute) }\end{array}$ & $\begin{array}{c}\text { Flow direction under } \\
\text { pumping conditions }\end{array}$ \\
\hline 65 & Turbulent & - & 0.80 & Up \\
78 & 0.50 & Down & .24 & Up \\
100 & .15 & Down & .10 & Up \\
122 & .05 & Down & .07 & Up \\
145 & .03 & Down & .09 & Up \\
164 & .02 & Down & .11 & Up \\
184 & - & - & .10 & Up \\
202 & No flow & - & .14 & Up \\
212 & - & - & .15 & Up \\
\hline
\end{tabular}

Under nonpumping conditions, the video log shows water entering the borehole through horizontal to low-angle fractures at 70 to $72 \mathrm{ft}$ bls, no visible flow at $110 \mathrm{ft}$ bls, and a possible water-receiving zone at about $134 \mathrm{ft}$ bls. Low-angle fractures appear to be relatively common, most near vertical fractures appear to be filled (calcite or gypsum?).

A submersible pump was placed at $55 \mathrm{ft}$ bls, and the borehole was pumped at a rate that ranged from about 0.9 to $1.5 \mathrm{gal} / \mathrm{min}$. The water level in the borehole declined $5.75 \mathrm{ft}$ after 1 hour and 41 minutes of pumping. Under pumping conditions, the heatpulse flowmeter measured upward flow at 65, 78, 100, $122,145,164,184,202,212$, and $218 \mathrm{ft}$ bls. The suite of borehole geophysical logs and heatpulse-flowmeter data indicate, under pumping conditions, water enters the borehole below a depth of $218 \mathrm{ft}$ and flows upward. Minor water-receiving zones are present from a depth of about 110 to $200 \mathrm{ft}$ bls. Additional water enters the borehole through the minor fractures at 60 to 73,83 to 86 , and $95 \mathrm{ft}$ bls. 


\section{MO-638 (RW43)}

Monitor well MO-638 was logged March 28, 1996. The caliper log shows the borehole is drilled to a depth of $56 \mathrm{ft}$ bls and is cased with 6-in.-diameter casing to $14 \mathrm{ft}$ bls (fig. 9). The caliper log shows a major fracture from 35 to $36 \mathrm{ft}$ bls plus minor fractures throughout the openhole interval. The fluid-resistivity and fluid-temperature logs show only minor changes in slope. Under nonpumping conditions, the heatpulse flowmeter measured variable, upward borehole flow at 17, 23, 42, and $50 \mathrm{ft}$ bls (table 12). Variations in measurements probably are caused by nearby pumping wells. The suite of geophysical logs and heatpulse-flowmeter data indicate most water enters the borehole through the fracture at $52 \mathrm{ft}$ bls, moves upward, and exits the borehole through fractures at 14 to $16 \mathrm{ft}$ bls.

Table 12. Summary of heatpulse-flowmeter measurements for borehole MO-638 (RW43) on March 28, 1996, at the Butz Landfill Superfund Site, Jackson Township, Monroe County, Pennsylvania

\begin{tabular}{ccc}
\hline $\begin{array}{c}\text { Depth } \\
\text { (feet below land } \\
\text { surface) }\end{array}$ & $\begin{array}{c}\text { Flow rate under } \\
\text { nonpumping conditions } \\
\text { (gallon per minute) }\end{array}$ & $\begin{array}{c}\text { Flow direction } \\
\text { under nonpumping } \\
\text { conditions }\end{array}$ \\
\hline 17 & 0.10 & $\mathrm{Up}$ \\
23 & .08 to .20 & $\mathrm{Up}$ \\
42 & .10 to .20 & $\mathrm{Up}$ \\
50 & .17 & $\mathrm{Up}$ \\
\hline
\end{tabular}




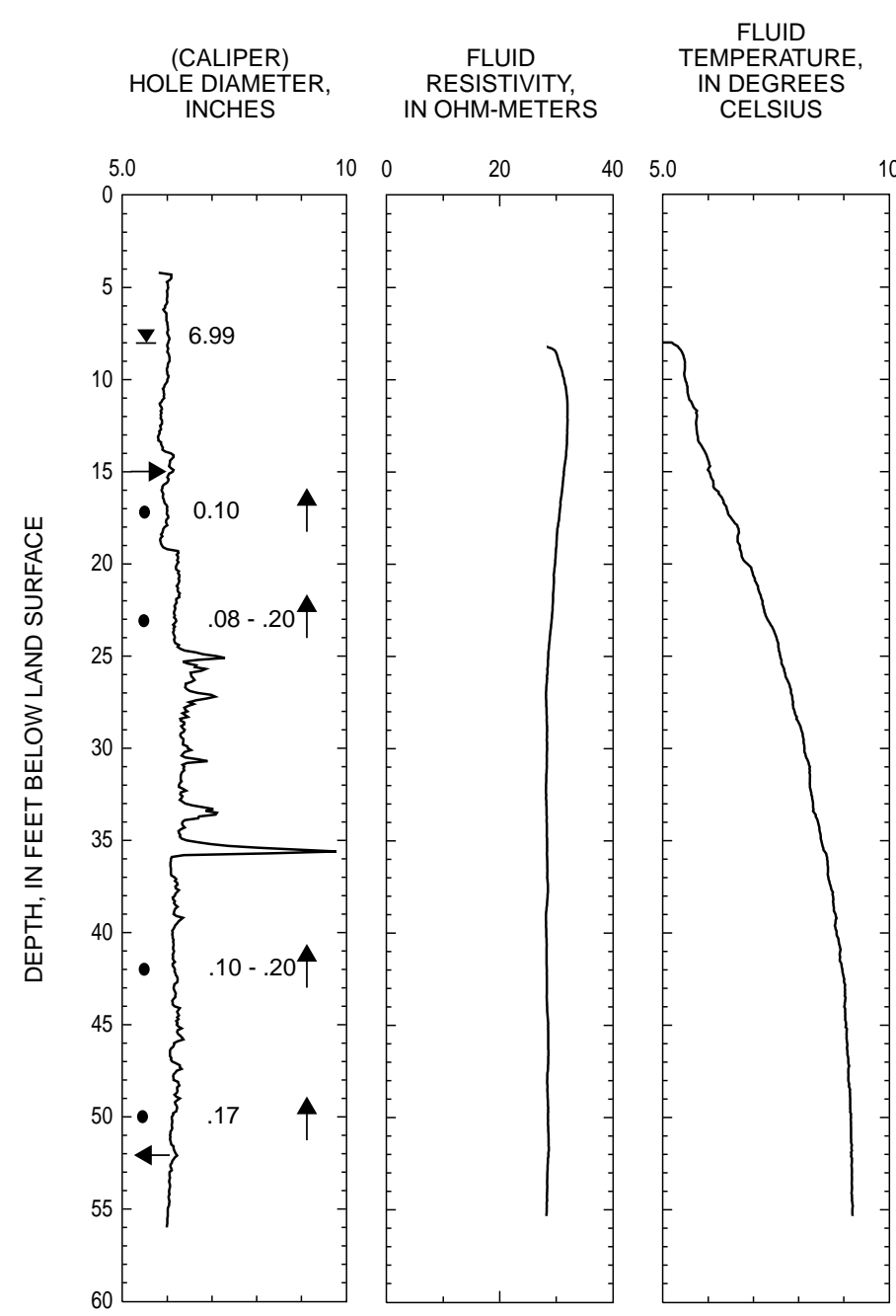

\section{EXPLANATION}

7 6.99 STATIC WATER LEVEL-Measured in well at the time of geophysical logging

- 0.10 BOREHOLE-FLOW MEASUREMENT UNDER NONPUMPING CONDITIONS- Circle at depth of flow measurement. Number is measured flow in gallons per minute.

DIRECTION OF BOREHOLE FLOW UNDER NONPUMPING CONDITIONS

$\leftarrow \quad$ KNOWN (OR INFERRED) WATER-PRODUCING ZONE UNDER NONPUMPING CONDITIONS

$\rightarrow \quad$ KNOWN (OR INFERRED) WATER-RECEIVING ZONE UNDER NONPUMPING CONDITIONS

Figure 9. Borehole geophysical logs and direction of borehole flow under nonpumping conditions within MO-638 (RW43), collected on March 28, 1996, Butz Landfill Superfund Site, Jackson Township, Monroe County, Pennsylvania. 


\section{MO-639 (RW50)}

Monitor well MO-639 was logged April 3, 1996. The caliper log shows this borehole is drilled to a depth of $88 \mathrm{ft}$ bls and is cased with 6-in.-diameter casing to $66 \mathrm{ft}$ bls (fig. 10). The caliper log shows a major fracture at $84 \mathrm{ft}$ bls plus numerous minor fractures below the bottom of the casing. The fluid-resistivity log shows minor changes in slope at 68 and $78 \mathrm{ft}$ bls that correlate to minor fractures on the caliper log. Under nonpumping conditions, the heatpulse flowmeter measured upward borehole flow at 20,30, 40, 54, and $74 \mathrm{ft}$ bls (table 13). The suite of geophysical logs and heatpulse-flowmeter data indicate water enters the borehole through fractures at 78 to $87 \mathrm{ft}$ bls and moves upward. Some water exits the borehole through the fracture at 66 to $68 \mathrm{ft}$ bls. The remaining water moves up the borehole and exits through breaks in casing at 14,35 , and $46 \mathrm{ft}$ bls with possible lateral flow at $25 \mathrm{ft}$ bls.

Table 13. Summary of heatpulse-flowmeter measurements for borehole MO-639 (RW50) on April 3, 1996, at the Butz Landfill Superfund Site, Jackson Township, Monroe County, Pennsylvania

\begin{tabular}{ccc}
\hline $\begin{array}{c}\text { Depth } \\
\text { (feet below land } \\
\text { surface) }\end{array}$ & $\begin{array}{c}\text { Flow rate under } \\
\text { nonpumping conditions } \\
\text { (gallons per minute) }\end{array}$ & $\begin{array}{c}\text { Flow direction } \\
\text { under nonpumping } \\
\text { conditions }\end{array}$ \\
\hline 20 & 0.07 & $\mathrm{Up}$ \\
30 & .08 & $\mathrm{Up}$ \\
40 & .14 & $\mathrm{Up}$ \\
54 & .27 & $\mathrm{Up}$ \\
74 & .70 & $\mathrm{Up}$ \\
\hline
\end{tabular}




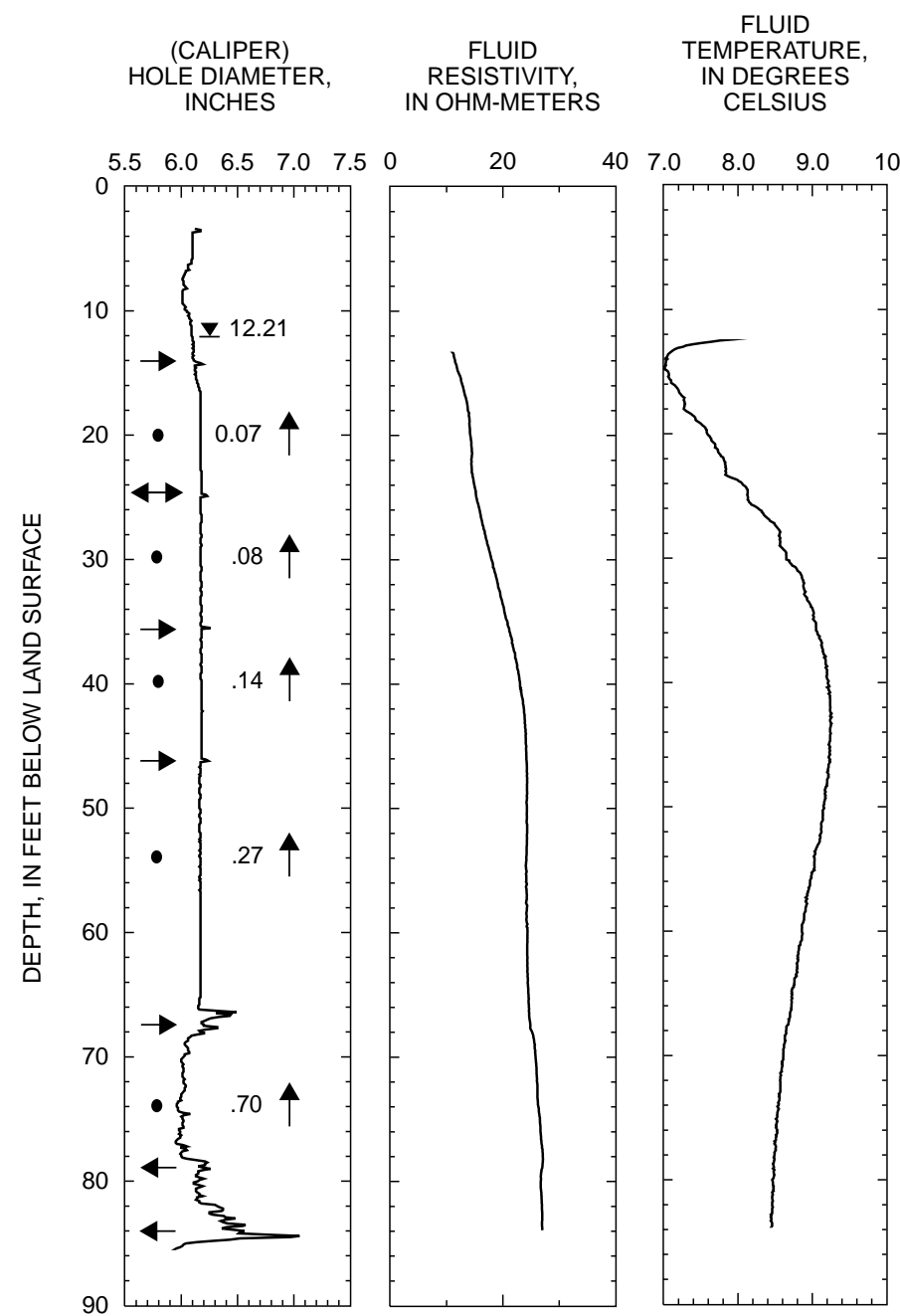

\section{EXPLANATION}

7 12.21 STATIC WATER LEVEL-Measured in well at the time of geophysical logging

- 0.07 BOREHOLE-FLOW MEASUREMENT UNDER NONPUMPING CONDITIONS- Circle at depth of flow measurement. Number is measured flow in gallons per minute.

DIRECTION OF BOREHOLE FLOW UNDER NONPUMPING

$\uparrow \quad$ KNOWN (OR INFERRED) WATER-PRODUCING ZONE UNDER

$\leftarrow \quad$ NONPUMPING CONDITIONS

$\rightarrow \quad$ KNOWN (OR INFERRED) WATER-RECEIVING ZONE UNDER NONPUMPING CONDITIONS

$\leftrightarrow \quad$ LATERAL FLOW (INFERRED)

Figure 10. Borehole geophysical logs and direction of borehole flow under nonpumping conditions within MO-639 (RW50), collected on April 3, 1996, Butz Landfill Superfund Site, Jackson Township, Monroe County, Pennsylvania. 


\section{MO-640 (RW52)}

Monitor well MO-640 was logged April 2, 1996, and July 21, 1999. The caliper log shows the borehole is drilled to a depth of $122 \mathrm{ft}$ bls and is cased with 6-in.-diameter casing to $50 \mathrm{ft}$ bls (fig. 11). The caliper log shows encrustation on the casing from 10 to $17 \mathrm{ft}$ bls, possible cracks or seams in the casing at 10 and $30 \mathrm{ft}$ bls, and major fractures at 51, 64 to 66, 86, 98, and 106 to $108 \mathrm{ft}$ bls plus numerous minor fractures throughout the openhole interval. The fluid-resistivity log shows changes in slope at 52, 66, 75, and $98 \mathrm{ft}$ bls that correlate closely with fractures identified on the caliper log. The fluid-temperature $\log$ shows major changes in slope at 18 and $40 \mathrm{ft}$ bls. Under nonpumping conditions, the heatpulse flowmeter measured downward borehole flow at 80 and $94 \mathrm{ft}$ bls and no flow at 60 and $110 \mathrm{ft}$ bls (table 14). The suite of borehole geophysical logs and heatpulse-flowmeter data indicate, under nonpumping conditions, possible flow within the casing from about 18 to $30 \mathrm{ft}$ bls and possible lateral flow at $50 \mathrm{ft}$ bls. Water enters the borehole through the fractures at 64 to 66,75 , and possibly at $90 \mathrm{ft} \mathrm{bls,} \mathrm{moves} \mathrm{downward,} \mathrm{and} \mathrm{exits} \mathrm{the}$ borehole through the fractures from 98 to $108 \mathrm{ft}$ bls.

\begin{tabular}{|c|c|c|}
\hline \multicolumn{3}{|c|}{$[-$, not determined $]$} \\
\hline $\begin{array}{l}\text { Depth } \\
\text { (feet below land } \\
\text { surface) }\end{array}$ & $\begin{array}{l}\text { Flow rate under } \\
\text { nonpumping conditions } \\
\text { (gallons per minute) }\end{array}$ & $\begin{array}{l}\text { Flow direction under } \\
\text { nonpumping conditions }\end{array}$ \\
\hline 60 & No flow & - \\
\hline 80 & 1.19 & Down \\
\hline 94 & 1.25 & Down \\
\hline 110 & No flow & - \\
\hline
\end{tabular}

The caliper $\log$ of July 21, 1999, is similar to that collected on April 2, 1996. The fluid-resistivity log shows several minor deflections at 52, 65, 76, 86, 91, 99, and 102 to $119 \mathrm{ft}$ bls that correlate closely with fractures identified on the caliper log. The fluid-temperature log shows minor deflections at 112 and $118 \mathrm{ft} \mathrm{bls}$. Under nonpumping conditions, the heatpulse-flowmeter measured upward flow at 55, 61, and $102 \mathrm{ft} \mathrm{bls,} \mathrm{downward} \mathrm{flow} \mathrm{at} 80$ and $95 \mathrm{ft}$ bls, and no flow at $114 \mathrm{ft}$ bls (table 15). The suite of borehole geophysical logs and heatpulse-flowmeter data indicate, under nonpumping conditions, water enters the borehole through fractures at 65 to 66, 76, and 109 to $110 \mathrm{ft}$ bls, moves up, and exits the borehole through the fractures at 57 and $98 \mathrm{ft}$ bls.

Table 15. Summary of heatpulse-flowmeter measurements for borehole MO-640 (RW52) on July 21, 1999, at the Butz Landfill Superfund Site, Jackson Township, Monroe County, Pennsylvania

[-, not determined]

\begin{tabular}{ccccc}
\hline $\begin{array}{c}\text { Depth } \\
\text { (feet below land } \\
\text { surface) }\end{array}$ & $\begin{array}{c}\text { Flow rate under } \\
\text { nonpumping conditions } \\
\text { (gallons per minute) }\end{array}$ & $\begin{array}{c}\text { Flow direction under } \\
\text { nonpumping conditions }\end{array}$ & $\begin{array}{c}\text { Flow rate under } \\
\text { pumping conditions } \\
\text { (gallons per minute) }\end{array}$ & $\begin{array}{c}\text { Flow direction under } \\
\text { pumping conditions }\end{array}$ \\
\hline 55 & 0.20 & $\mathrm{Up}$ & 0.50 & $\mathrm{Up}$ \\
61 & .30 & $\mathrm{Up}$ & .60 & $\mathrm{Up}$ \\
80 & .07 & Down & .20 & $\mathrm{Up}$ \\
95 & .07 & Down & .15 & $\mathrm{Up}$ \\
102 & .20 & $\mathrm{Up}$ & No flow & - \\
114 & No flow & - & No flow & - \\
\hline
\end{tabular}




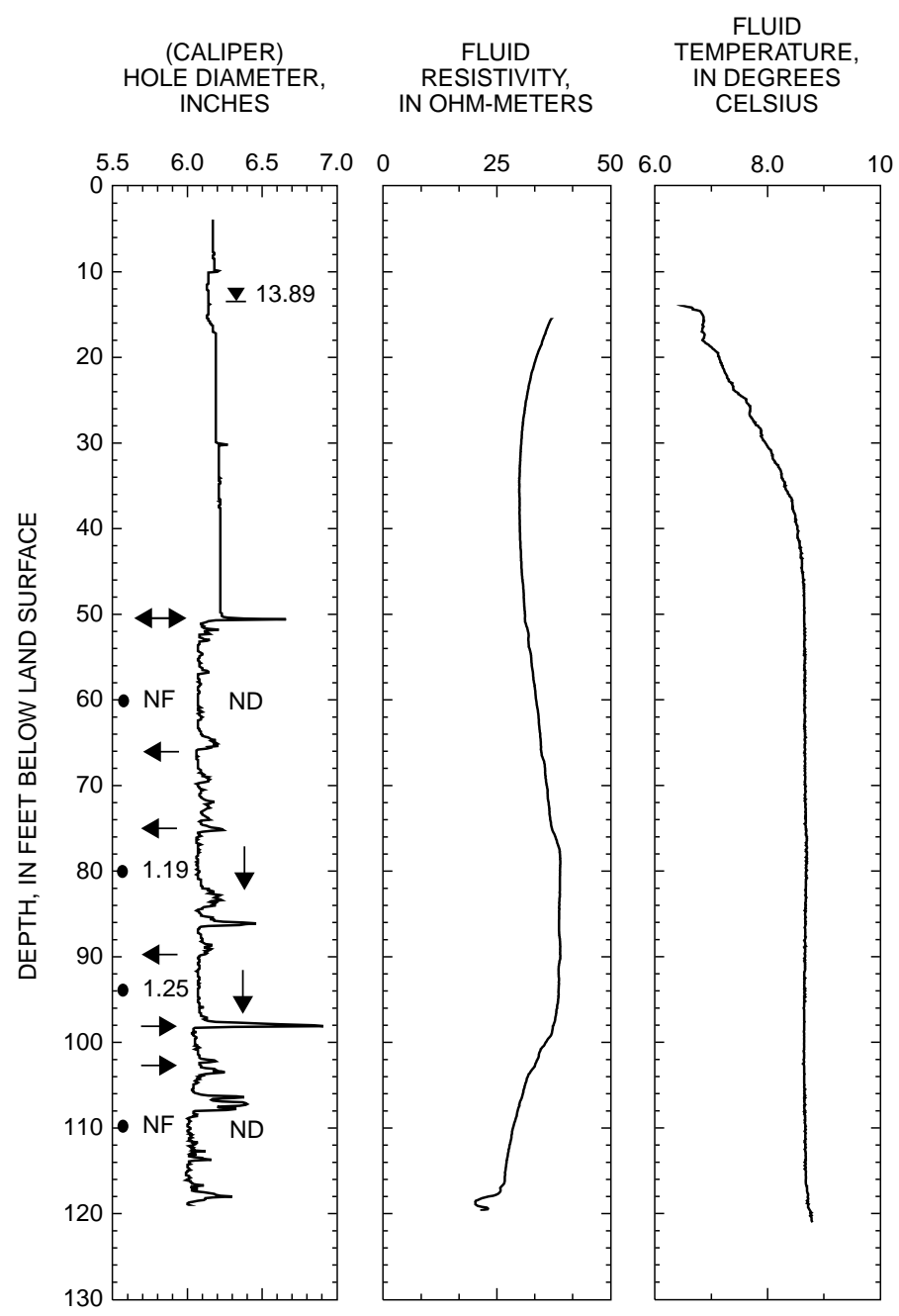

\section{EXPLANATION}

₹ 13.89 STATIC WATER LEVEL-Measured in well at the time of geophysical logging

- 1.25 BOREHOLE-FLOW MEASUREMENT UNDER NONPUMPING CONDITIONS - Circle at depth of flow measurement. Number is measured flow in gallons per minute.

$\downarrow \quad$ DIRECTION OF BOREHOLE FLOW UNDER NONPUMPING CONDITIONS

$\leftarrow \quad$ KNOWN (OR INFERRED) WATER-PRODUCING ZONE UNDER NONPUMPING CONDITIONS

$\rightarrow \quad$ KNOWN (OR INFERRED) WATER-RECEIVING ZONE UNDER NONPUMPING CONDITIONS

$\leftrightarrow \quad$ LATERAL FLOW (INFERRED)

NF NO FLOW

ND NOT DETERMINED

Figure 11. Borehole geophysical logs and direction of borehole flow under nonpumping conditions within MO-640 (RW52), collected on April 2, 1996, Butz Landfill Superfund Site, Jackson Township, Monroe County, Pennsylvania. 
Under nonpumping conditions, the video log shows the water is very cloudy (low visibility of the casing and borehole) from the water surface to a depth of about $65 \mathrm{ft}$ bls but clears considerably by a depth of $70 \mathrm{ft}$ bls. Water was observed entering the borehole from the water-producing fracture at a depth of about $74 \mathrm{ft}$ bls and leaving the borehole at a depth of about $98 \mathrm{ft}$ bls. Horizontal to low-angle fractures are common throughout the borehole. Near vertical fractures are less common and were observed to a depth of about $97 \mathrm{ft}$ bls.

A submersible pump was placed at $42 \mathrm{ft}$ bls, and the borehole was pumped at a rate of about $1.0 \mathrm{gal} / \mathrm{min}$. The water level in the borehole declined $0.28 \mathrm{ft}$ after 53 minutes of pumping. Under pumping conditions, the heatpulse flowmeter measured upward flow at 55, 61, 80, and $95 \mathrm{ft}$ bls and no flow at 102 and $114 \mathrm{ft}$ bls (table 15). The suite of borehole geophysical logs and heatpulse-flowmeter data indicate, under pumping conditions, water enters the borehole at 65 to 66,76 , and $98 \mathrm{ft}$ bls, moves up, and exits the borehole at $57 \mathrm{ft}$ bls.

\section{MO-641 (R1 1A)}

Monitor well MO-641 was logged March 7, 1996. The caliper log shows this borehole is drilled to a depth of $201 \mathrm{ft}$ bls and is cased with 6-in.-diameter casing to $18 \mathrm{ft} \mathrm{bls} \mathrm{(fig.} \mathrm{12).} \mathrm{The} \mathrm{caliper} \mathrm{log} \mathrm{shows} \mathrm{major}$ fractures at 36 to 38 and 186 to $188 \mathrm{ft}$ bls plus numerous minor and smaller fractures throughout the openhole interval. The fluid-resistivity log shows changes in slope at 90 and $188 \mathrm{ft}$ bls that correlate to fractures shown on the caliper log. The fluid-temperature log shows a consistent fluid-temperature increase from approximately 70 to $188 \mathrm{ft}$ bls, indicating no vertical borehole flow. Under nonpumping conditions, the heatpulse-flowmeter measurements indicate no borehole flow at 30,42, 62, 96, and $158 \mathrm{ft}$ bls (table 16).

A submersible pump was placed at $25 \mathrm{ft}$ bls and the borehole was pumped at a rate less than $1.0 \mathrm{gal} / \mathrm{min}$. Because of low borehole yield, the pump was then lowered to $37 \mathrm{ft}$ bls and pumped at a rate less than $0.5 \mathrm{gal} / \mathrm{min}$. The water level in the borehole declined $12.11 \mathrm{ft}$ after 1 hour and 47 minutes of pumping and never stabilized, even when discharge was decreased to $0.2 \mathrm{gal} / \mathrm{min}$. Because of the low yield of the borehole, no water-producing zones within the borehole could be defined with the heatpulse flowmeter. The fluid-resistivity log, however, indicates possible water-producing zones at 83 to 92 and 186 to $188 \mathrm{ft}$ bls. The fluid-temperature log indicates possible water production from the formation above $60 \mathrm{ft}$ bls.

Table 16. Summary of heatpulse-flowmeter measurements for borehole MO-641 (R1_1A) on March 7, 1996, at the Butz Landfill Superfund Site, Jackson Township, Monroe County, Pennsylvania

$[-$, not determined]

\begin{tabular}{ccc}
\hline $\begin{array}{c}\text { Depth } \\
\text { (feet below land } \\
\text { surface) }\end{array}$ & $\begin{array}{c}\text { Flow rate under } \\
\text { nonpumping conditions } \\
\text { (gallons per minute) }\end{array}$ & $\begin{array}{c}\text { Flow direction under } \\
\text { nonpumping conditions }\end{array}$ \\
\hline 30 & No flow & - \\
42 & No flow & - \\
62 & No flow & - \\
96 & No flow & - \\
158 & No flow & \\
\hline
\end{tabular}




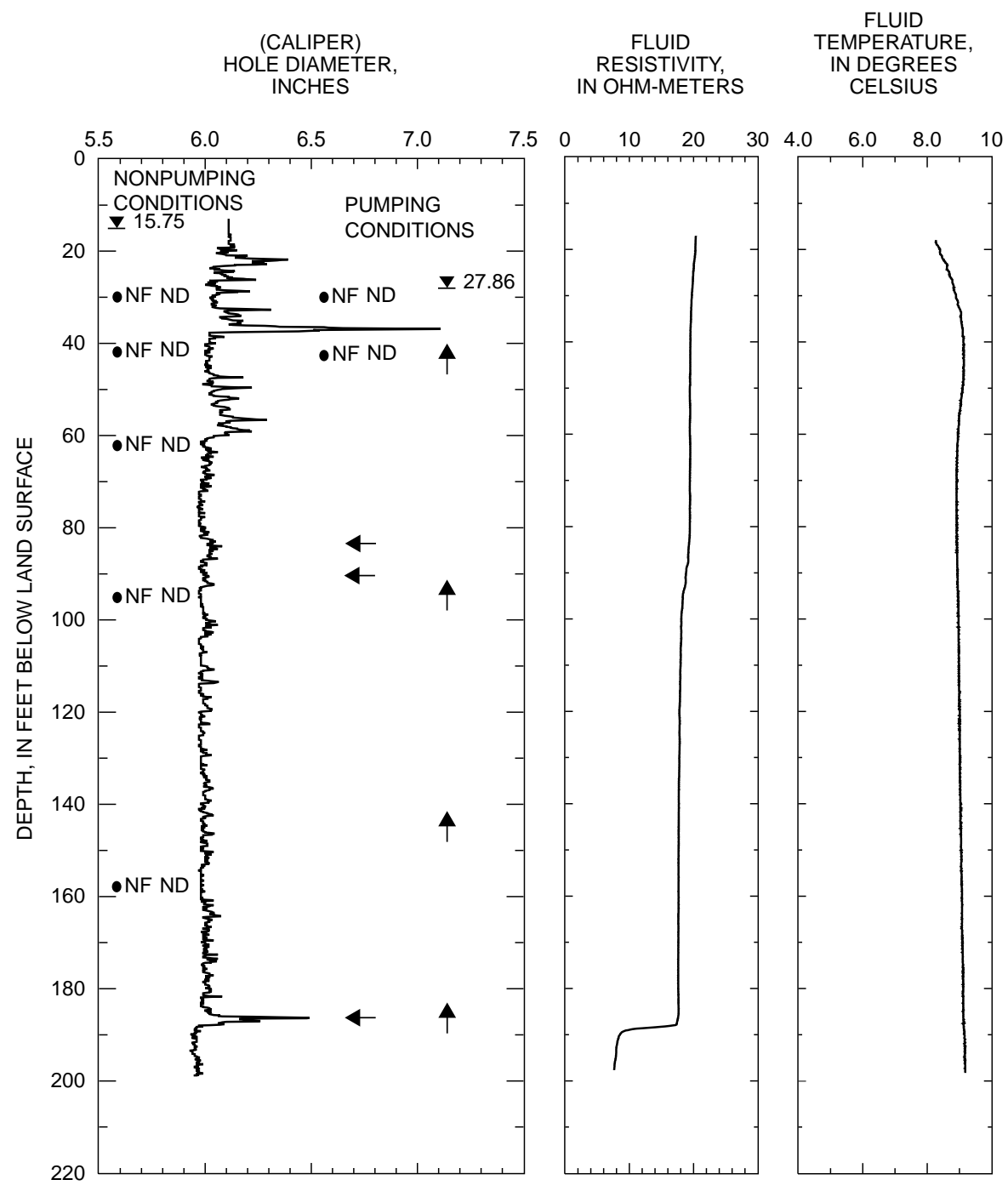

\section{EXPLANATION}

7 15.75 STATIC WATER LEVEL-Measured in well at the time of geophysical logging

- NF BOREHOLE-FLOW MEASUREMENT UNDER NONPUMPING AND PUMPING CONDITIONS - Circle at depth of flow measurement. Number is measured flow in gallons per minute.

A DIRECTION OF BOREHOLE FLOW UNDER PUMPING CONDITIONS

$4 \quad$ INFERRED WATER-PRODUCING ZONE UNDER PUMPING CONDITIONS

NF NO FLOW

ND NOT DETERMINED

Figure 12. Borehole geophysical logs and direction of borehole flow under nonpumping and pumping conditions within MO-641 (R1_1A), collected on March 7, 1996, Butz Landfill Superfund Site, Jackson Township, Monroe County, Pennsylvania. 


\section{MO-642 (R1S)}

Monitor well MO-642 was logged April 5, 1996. The caliper log shows this borehole is drilled to a depth of $98.7 \mathrm{ft}$ bls, is cased with 6-in.-diameter casing to $25 \mathrm{ft}$ bls, and is heavily encrusted to the bottom of casing (fig. 13). The caliper log shows only minor fractures at 88, 90, and $93 \mathrm{ft}$ bls. The fluid-resistivity $\log$ shows a minor change in slope at $94 \mathrm{ft}$ bls that correlates to a fracture shown on the caliper log. The fluidtemperature log shows minor deflections in slope at 18,32 , and $45 \mathrm{ft}$ bls that indicate possible waterproducing and water-receiving zones. Under nonpumping conditions, the heatpulse flowmeter measured upward borehole flow at 20,40,60, and $80 \mathrm{ft}$ bls (table 17). The suite of geophysical logs and heatpulseflowmeter data indicate most water enters the borehole through the fracture at approximately $93 \mathrm{ft}$ bls and moves upward. About half of the water exits the borehole through fractures between 25 and $40 \mathrm{ft}$ bls, and the remainder exits the borehole through a break in casing above $20 \mathrm{ft}$ bls.

Table 17. Summary of heatpulse-flowmeter measurements for borehole MO-642 (R1S) on April 5, 1996, at the Butz Landfill Superfund Site, Jackson Township, Monroe County, Pennsylvania

\begin{tabular}{ccc}
\hline $\begin{array}{c}\text { Depth } \\
\text { (feet below land } \\
\text { surface) }\end{array}$ & $\begin{array}{c}\text { Flow rate under } \\
\text { nonpumping conditions } \\
\text { (gallon per minute) }\end{array}$ & $\begin{array}{c}\text { Flow direction under } \\
\text { nonpumping conditions }\end{array}$ \\
\hline 20 & 0.08 & $\mathrm{Up}$ \\
40 & .16 & $\mathrm{Up}$ \\
60 & .14 & $\mathrm{Up}$ \\
80 & .13 & $\mathrm{Up}$ \\
\hline
\end{tabular}




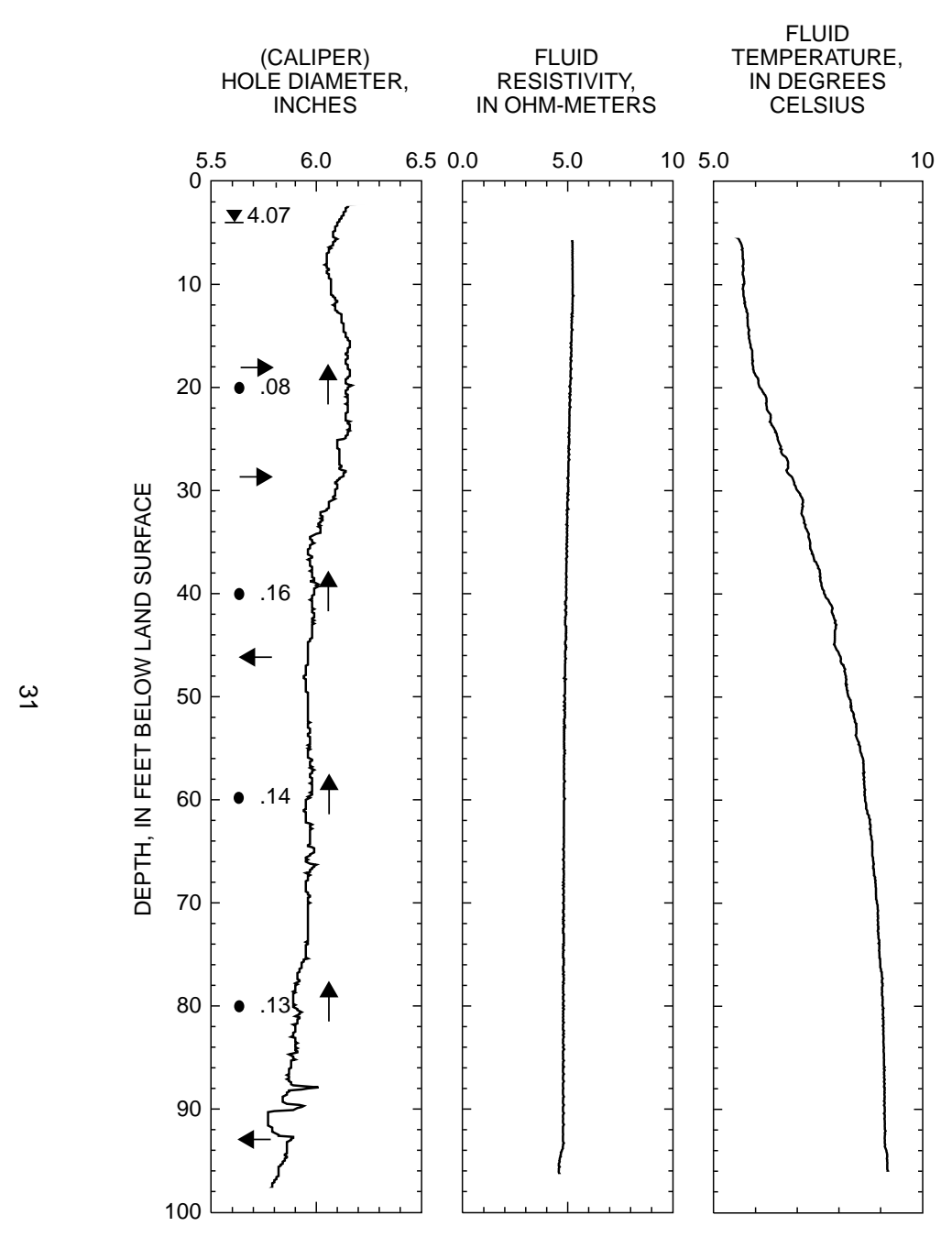

\section{EXPLANATION}

7 4.07 STATIC WATER LEVEL-Measured in well at the time of geophysical logging

- 0.08 BOREHOLE-FLOW MEASUREMENT UNDER NONPUMPING CONDITIONS - Circle at depth of flow measurement. Number is measured flow in gallon per minute.

DIRECTION OF BOREHOLE FLOW UNDER NONPUMPING CONDITIONS

$\leftarrow \quad$ KNOWN (OR INFERRED) WATER-PRODUCING ZONE UNDER NONPUMPING CONDITIONS

$\rightarrow \quad$ KNOWN (OR INFERRED) WATER-RECEIVING ZONE UNDER NONPUMPING CONDITIONS

Figure 13. Borehole geophysical logs and direction of borehole flow under nonpumping conditions within MO-642 (R1S), collected on April 5, 1996, Butz Landfill Superfund Site, Jackson Township, Monroe County, Pennsylvania. 


\section{MO-643 (R1D)}

Monitor well MO-643 was logged March 14, 1996. The caliper log shows this borehole is drilled to a depth of $241 \mathrm{ft}$ bls and is cased with 6-in.-diameter casing to $103 \mathrm{ft}$ bls (fig. 14). The caliper log shows a major fracture at 155 to $157 \mathrm{ft}$ bls plus numerous minor fractures throughout the openhole interval. The fluid-resistivity and fluid-temperature logs show a change in slope at $47 \mathrm{ft}$ bls that may indicate water flowing within the casing. Under nonpumping conditions, the heatpulse flowmeter measurements indicate no borehole flow at 132 and $190 \mathrm{ft}$ bls (table 18).

A submersible pump was placed at $50 \mathrm{ft}$ bls, and the borehole was pumped at a rate less than $1.0 \mathrm{gal} / \mathrm{min}$. The water level in the borehole declined $9.60 \mathrm{ft}$ after 51 minutes of pumping before stabilizing. Under pumping conditions, the heatpulse flowmeter measured upward borehole flow at $132 \mathrm{ft}$ bls and no flow at $190 \mathrm{ft}$ bls (table 18). The suite of geophysical logs and heatpulse-flowmeter data indicate the fracture at 155 to $157 \mathrm{ft}$ bls is the major water-producing zone in the borehole.

Table 18. Summary of heatpulse-flowmeter measurements for borehole MO-643 (R1D) on March 14, 1996, at the Butz Landfill Superfund Site, Jackson Township, Monroe County, Pennsylvania

$[-$, not determined $]$

\begin{tabular}{ccccc}
\hline $\begin{array}{c}\text { Depth } \\
\text { (feet below land } \\
\text { surface) }\end{array}$ & $\begin{array}{c}\text { Flow rate under } \\
\text { nonpumping conditions } \\
\text { (gallons per minute) }\end{array}$ & $\begin{array}{c}\text { Flow direction under } \\
\text { nonpumping conditions }\end{array}$ & $\begin{array}{c}\text { Flow rate under } \\
\text { pumping conditions } \\
\text { (gallons per minute) }\end{array}$ & $\begin{array}{c}\text { Flow direction under } \\
\text { pumping conditions }\end{array}$ \\
\hline 132 & No flow & - & 0.12 & Up \\
190 & No flow & - & No flow & - \\
\hline
\end{tabular}




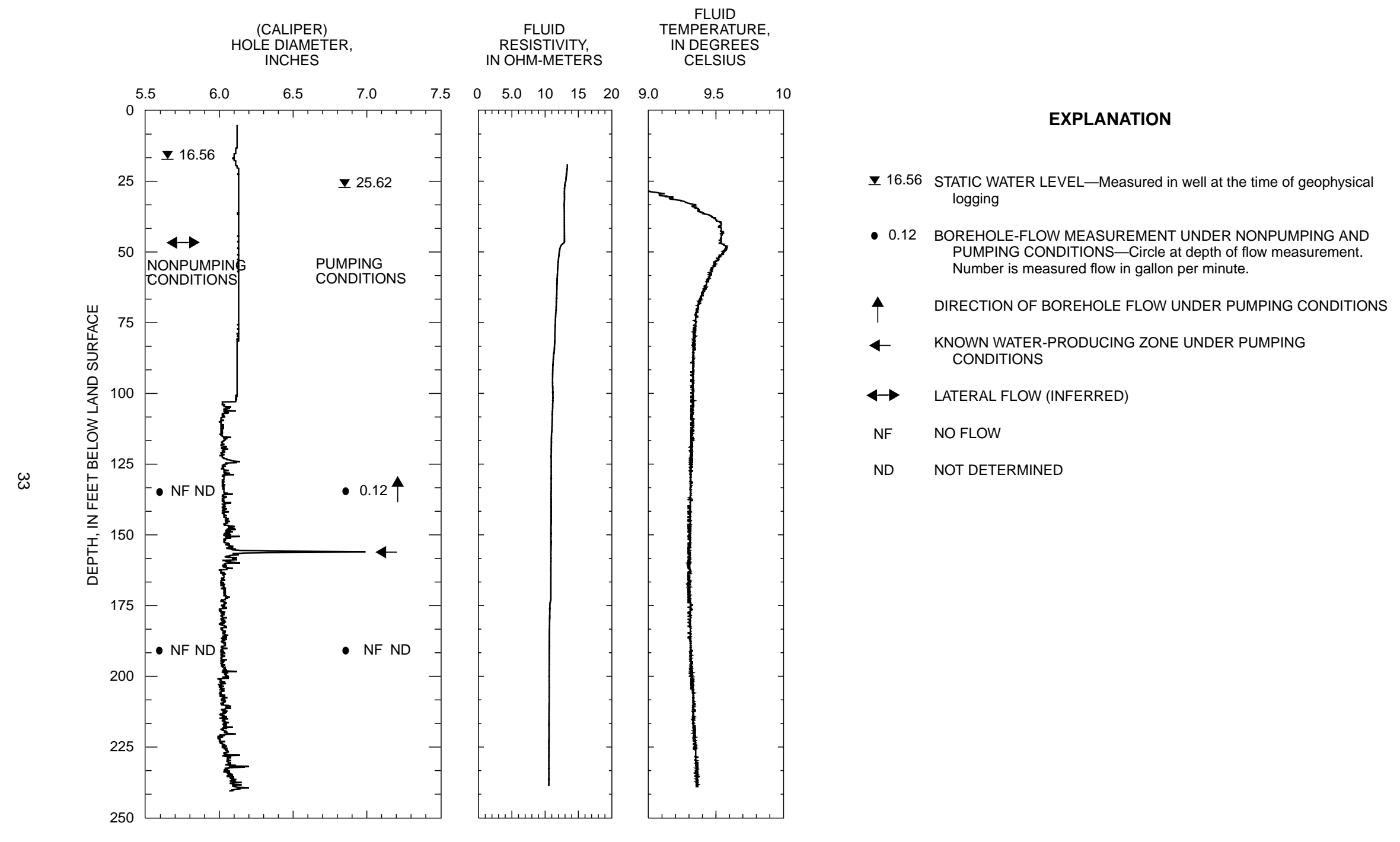

Figure 14. Borehole geophysical logs and direction of borehole flow under nonpumping and pumping conditions within MO-643 (R1D), collected on March 14, 1996, Butz Landfill Superfund Site, Jackson Township, Monroe County, Pennsylvania. 


\section{MO-644 (R2)}

Monitor well MO-644 was logged March 13, 1996. The caliper log shows this borehole is drilled to a depth of $132.5 \mathrm{ft}$ bls and is cased with 6-in.-diameter casing to $19 \mathrm{ft}$ bls (fig. 15). The caliper log shows major fractures at 26 to 28,44 to $45,83,95,101$, and $109 \mathrm{ft}$ bls plus numerous minor fractures throughout the openhole interval. The fluid-resistivity log shows changes in slope at 20 to 40 and $97 \mathrm{ft}$ bls that correlate with fractures on the caliper log, indicating possible water-producing fractures. The fluid-temperature log shows minor changes in slope at 20 to 28 and $97 \mathrm{ft}$ bls that correlate with fractures on the caliper log and indicate water-producing zones. Under nonpumping conditions, the heatpulse-flowmeter measurements indicate no borehole flow at 42, 78, 92, 106, and $114 \mathrm{ft}$ bls (table 19).

A submersible pump was placed at $50 \mathrm{ft}$ bls, and the borehole was pumped at approximately $0.6 \mathrm{gal} / \mathrm{min}$. The water level in the borehole declined $1.9 \mathrm{ft}$ after 1 hour of pumping and never completely stabilized. Under pumping conditions, the heatpulse flowmeter measured upward borehole flow at 42, 50, $78,92,106$, and $114 \mathrm{ft}$ bls. The fractures at 95 to $101 \mathrm{ft}$ bls produce about 75 percent of the flow, and the fracture at 109 to $111 \mathrm{ft}$ bls produced about 25 percent of the flow. The suite of geophysical logs and heatpulse-flowmeter data indicate the fracture zone at 95 to $101 \mathrm{ft}$ bls is the major water-producing zone in the borehole and lesser quantities of water are produced at 109 to $111 \mathrm{ft}$ bls and below $114 \mathrm{ft} \mathrm{bls}$.

Table 19. Summary of heatpulse-flowmeter measurements for borehole MO-644 (R2) on March 13, 1996, at the Butz Landfill Superfund Site, Jackson Township, Monroe County, Pennsylvania

[-, not determined]

\begin{tabular}{ccccc}
\hline $\begin{array}{c}\text { Depth } \\
\text { feet below land } \\
\text { surface) }\end{array}$ & $\begin{array}{c}\text { Flow rate under } \\
\text { nonpumping } \\
\text { conditions } \\
\text { (gallons per minute) }\end{array}$ & $\begin{array}{c}\text { Flow direction under } \\
\text { nonpumping } \\
\text { conditions }\end{array}$ & $\begin{array}{c}\text { Flow rate under } \\
\text { pumping conditions } \\
\text { (gallons per minute) }\end{array}$ & $\begin{array}{c}\text { Flow direction under } \\
\text { pumping conditions }\end{array}$ \\
\hline 42 & No flow & - & 1.1 & $\mathrm{Up}$ \\
50 & - & - & 1.1 & $\mathrm{Up}$ \\
78 & No flow & - & 1.1 & $\mathrm{Up}$ \\
92 & No flow & - & 1.1 & $\mathrm{Up}$ \\
106 & No flow & - & .30 & $\mathrm{Up}$ \\
\hline
\end{tabular}




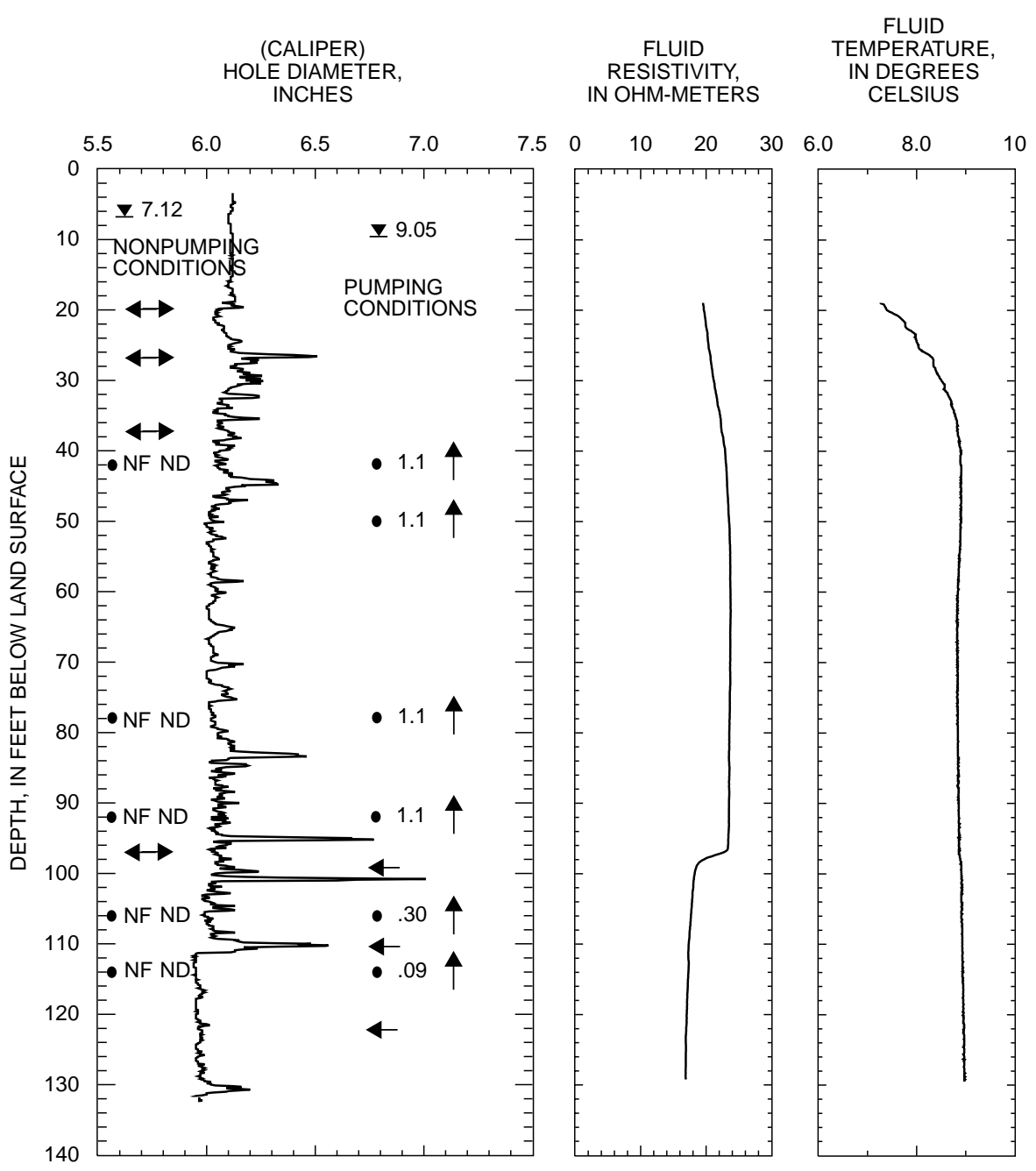

\section{EXPLANATION}

7.12 STATIC WATER LEVEL-Measured in well at the time of geophysica logging

- 1.1 BOREHOLE-FLOW MEASUREMENT UNDER NONPUMPING AND PUMPING CONDITIONS-Circle at depth of flow measurement. Number is measured flow in gallons per minute.

- DIRECTION OF BOREHOLE FLOW UNDER PUMPING CONDITIONS

$\leftarrow \quad$ KNOWN WATER-PRODUCING ZONE UNDER PUMPING CONDITIONS

$\leftrightarrow \quad$ LATERAL FLOW (INFERRED)

NF NO FLOW

ND NOT DETERMINED

Figure 15. Borehole geophysical logs and direction of borehole flow under nonpumping and pumping conditions within MO-644 (R2), collected on March 13, 1996, Butz Landfill Superfund Site, Jackson Township, Monroe County, Pennsylvania. 


\section{MO-645 (R3S)}

Monitor well MO-645 was logged March 28, 1996. The caliper log shows this borehole is drilled to a depth of $101 \mathrm{ft}$ bls and is cased with 6-in.-diameter casing to $40 \mathrm{ft}$ bls (fig. 16). The caliper log shows only minor fractures throughout the length of the openhole interval. The fluid-resistivity log shows a minor change in slope at $66 \mathrm{ft}$ bls that correlates to small fractures from 65 to 67 shown on the caliper log. Under nonpumping conditions, the heatpulse flowmeter measured no borehole flow at 57 and $87 \mathrm{ft}$ bls (table 20).

A submersible pump was placed at $38 \mathrm{ft}$ bls, and the borehole was pumped at a rate less than $0.25 \mathrm{gal} / \mathrm{min}$. The water level in the borehole declined $6.64 \mathrm{ft}$ after 32 minutes of pumping before beginning to stabilize. Under pumping conditions, the heatpulse-flowmeter measurements also show no borehole flow at 57 and $87 \mathrm{ft}$ bls (table 20). The suite of geophysical logs and heatpulse-flowmeter data indicate the fractures below casing at 40 to $56 \mathrm{ft}$ bls probably are the major water-producing zones in the borehole.

Table 20. Summary of heatpulse-flowmeter measurements for borehole MO-645 (R3S) on March 28, 1996, at the Butz Landfill Superfund Site, Jackson Township, Monroe County, Pennsylvania

$[-$, not determined]

\begin{tabular}{ccccc}
\hline $\begin{array}{c}\text { Depth } \\
\text { (feet below land } \\
\text { surface) }\end{array}$ & $\begin{array}{c}\text { Flow rate under } \\
\text { nonpumping } \\
\text { conditions } \\
\text { (gallons per minute) }\end{array}$ & $\begin{array}{c}\text { Flow direction under } \\
\text { nonpumping } \\
\text { conditions }\end{array}$ & $\begin{array}{c}\text { Flow rate under } \\
\text { pumping conditions } \\
\text { (gallons per minute) }\end{array}$ & $\begin{array}{c}\text { Flow direction under } \\
\text { pumping conditions }\end{array}$ \\
\hline 57 & No flow & - & No flow & - \\
87 & No flow & - & No flow & - \\
\hline
\end{tabular}




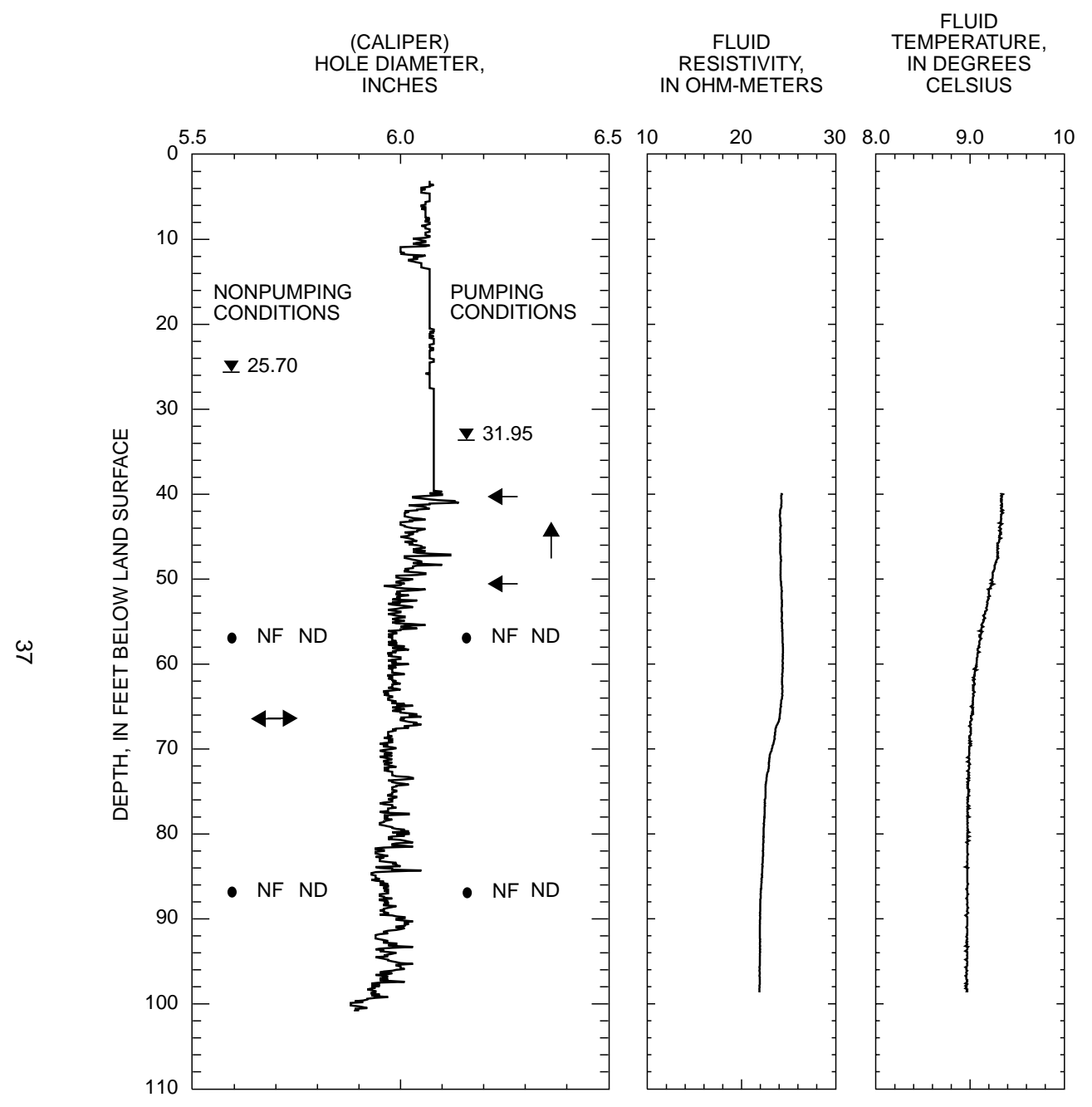

\section{EXPLANATION}

25.70 STATIC WATER LEVEL-Measured in well at the time of geophysical logging

- NF BOREHOLE-FLOW MEASUREMENT UNDER NONPUMPING AND PUMPING CONDITIONS- Circle at depth of flow measurement. Number is measured flow in gallons per minute.

4 DIRECTION OF BOREHOLE FLOW UNDER PUMPING CONDITIONS

$4 \quad$ KNOWN WATER-PRODUCING ZONE UNDER PUMPING CONDITIONS

$\leftrightarrow \quad$ LATERAL FLOW (INFERRED)

NF NO FLOW

ND NOT DETERMINED

Figure 16. Borehole geophysical logs and direction of borehole flow under nonpumping and pumping conditions within MO-645 (R3S), collected on March 28, 1996 Butz Landfill Superfund Site, Jackson Township, Monroe County, Pennsylvania. 


\section{MO-646 (R3D)}

Monitor well MO-646 was logged March 6, 1996. The caliper log shows this borehole is drilled to a depth of $239.5 \mathrm{ft}$ bls and is cased with 6-in.-diameter casing to $104 \mathrm{ft}$ bls (fig. 17). The caliper log shows major fractures at 120 and 148 to $151 \mathrm{ft}$ bls plus numerous minor fractures throughout the length of the openhole interval. The fluid-resistivity log shows changes in slope at 104 and $152 \mathrm{ft}$ bls that correlate to fractures shown on the caliper log. The fluid-temperature log shows a consistent fluid-temperature increase from approximately $150 \mathrm{ft}$ bls to the bottom of the borehole, indicating no vertical borehole flow. Under nonpumping conditions, the heatpulse flowmeter measured no borehole flow at 90, 126, 140, and $180 \mathrm{ft}$ bls (table 21).

A submersible pump was placed at $78 \mathrm{ft}$ bls, and the borehole was pumped at a rate less than $1.0 \mathrm{gal} / \mathrm{min}$. The water level in the borehole declined $3.75 \mathrm{ft}$ after 42 minutes of pumping and never completely stabilized. Under pumping conditions, the heatpulse flowmeter measured upward borehole flow at 90,126, and $140 \mathrm{ft}$ bls and no flow at $180 \mathrm{ft}$ bls (table 21). The suite of geophysical logs and heatpulse-flowmeter data indicate the greatest quantity of water enters the borehole through the major fracture at 148 to $151 \mathrm{ft}$ bls; a smaller amount of water is produced by a minor fracture at $130 \mathrm{ft}$ bls. Some water appears to be leaving the borehole at the minor fracture at the base of the casing.

Table 21. Summary of heatpulse-flowmeter measurements for borehole MO-646 (R3D) on March 6, 1996, at the Butz Landfill Superfund Site, Jackson Township, Monroe County, Pennsylvania

$[-$, not determined $]$

\begin{tabular}{ccccc}
\hline $\begin{array}{c}\text { Depth } \\
\text { (feet below land } \\
\text { surface) }\end{array}$ & $\begin{array}{c}\text { Flow rate under } \\
\text { nonpumping } \\
\text { conditions } \\
\text { (gallons per minute) }\end{array}$ & $\begin{array}{c}\text { Flow direction under } \\
\text { nonpumping } \\
\text { conditions }\end{array}$ & $\begin{array}{c}\text { Flow rate under } \\
\text { pumping conditions } \\
\text { (gallon per minute) }\end{array}$ & $\begin{array}{c}\text { Flow direction under } \\
\text { pumping conditions }\end{array}$ \\
\hline 90 & No flow & - & 0.07 & Up \\
126 & No flow & - & .15 & Up \\
140 & No flow & - & .10 & Up \\
180 & No flow & - & No flow & - \\
\hline
\end{tabular}

${ }^{1}$ Measurements affected by questionable integrity of seal between borehole and heatpulse flowmeter. 


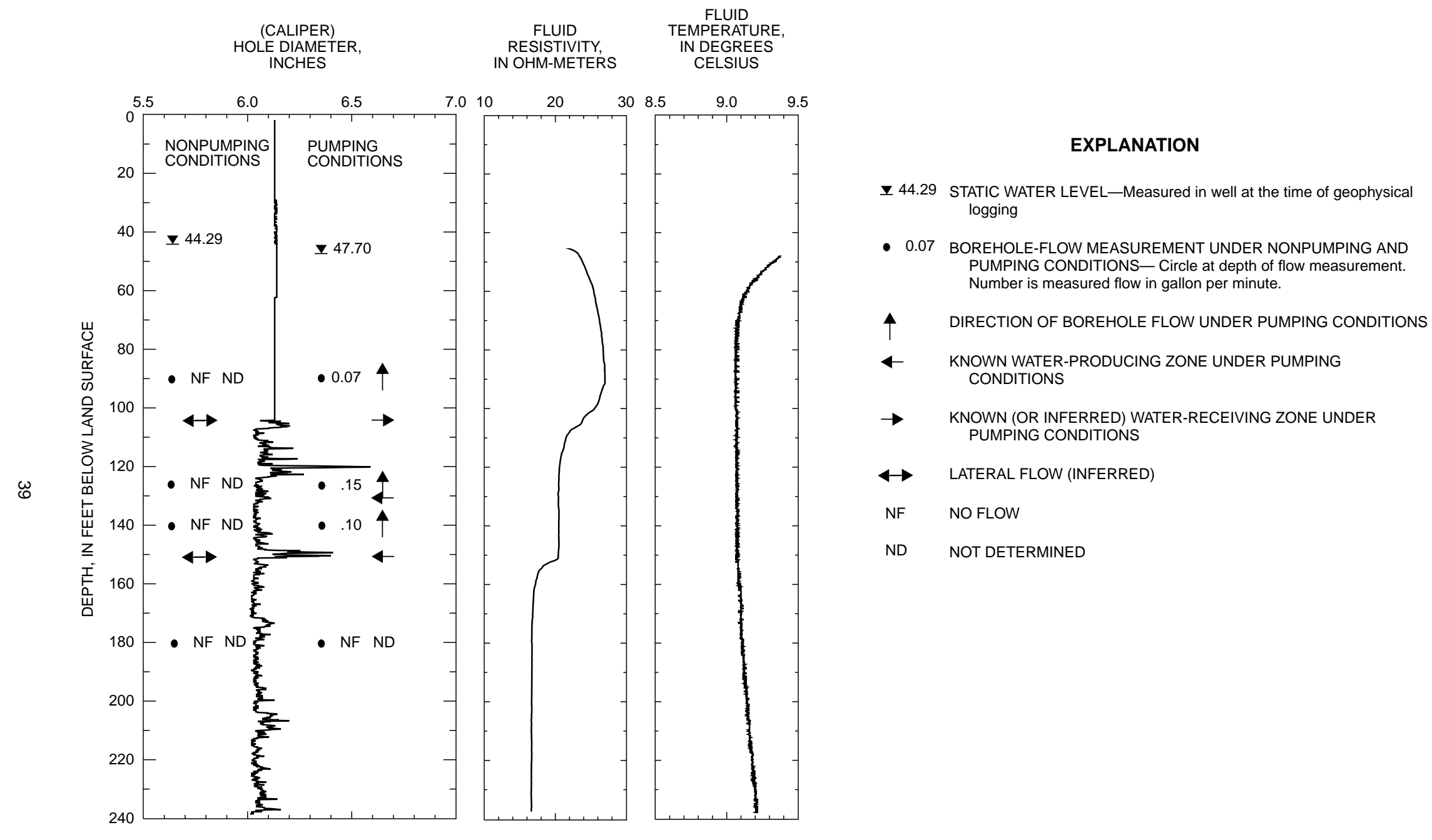

Figure 17. Borehole geophysical logs and direction of borehole flow under nonpumping and pumping conditions within MO-646 (R3D), collected on March 6, 1996, Butz Landfill Superfund Site, Jackson Township, Monroe County, Pennsylvania. 


\section{MO-647 (R4)}

Monitor well MO-647 was logged March 6, 1996. The caliper log shows this borehole is drilled to a depth of $147 \mathrm{ft}$ bls and is cased with 6-in.-diameter casing to $18 \mathrm{ft}$ bls (fig. 18). The caliper log shows a major fracture at 31 to $36 \mathrm{ft}$ bls and minor fractures at 24 to $26,42,70$ to 71 , and 137 to $138 \mathrm{ft}$ bls. The fluidresistivity and fluid-temperature logs show changes in slope at 31 and $33 \mathrm{ft} \mathrm{bls,} \mathrm{respectively,} \mathrm{that} \mathrm{correlate}$ with the major fracture shown on the caliper log, indicating a water-producing fracture. Under nonpumping conditions, the heatpulse flowmeter measured downward borehole flow at 45, 90, and $130 \mathrm{ft}$ bls and no borehole flow at 29 and $140 \mathrm{ft}$ bls (table 22). The suite of geophysical logs and heatpulseflowmeter data indicate the fracture at 31 to $36 \mathrm{ft}$ bls is the major water-producing fracture in the borehole. Water enters the borehole through fractures at 31 to $36 \mathrm{ft}$ bls, moves vertically downward, and exits the borehole through the fracture at 137 to $138 \mathrm{ft}$ bls.

Table 22. Summary of heatpulse-flowmeter measurements for borehole MO-647 (R4) on March 6, 1996, at the Butz Landfill Superfund Site, Jackson Township, Monroe County, Pennsylvania

$[-$, not determined]

\begin{tabular}{ccc}
\hline $\begin{array}{c}\text { Depth } \\
\text { (feet below land } \\
\text { surface) }\end{array}$ & $\begin{array}{c}\text { Flow rate under } \\
\text { nonpumping } \\
\text { conditions } \\
\text { (gallon per minute) }\end{array}$ & $\begin{array}{c}\text { Flow direction under } \\
\text { nonpumping } \\
\text { conditions } \\
\text { (gallons per minute) }\end{array}$ \\
\hline 29 & No flow & - \\
45 & 0.05 & Down \\
90 & .05 & Down \\
130 & .04 & Down \\
140 & No flow & - \\
\hline
\end{tabular}




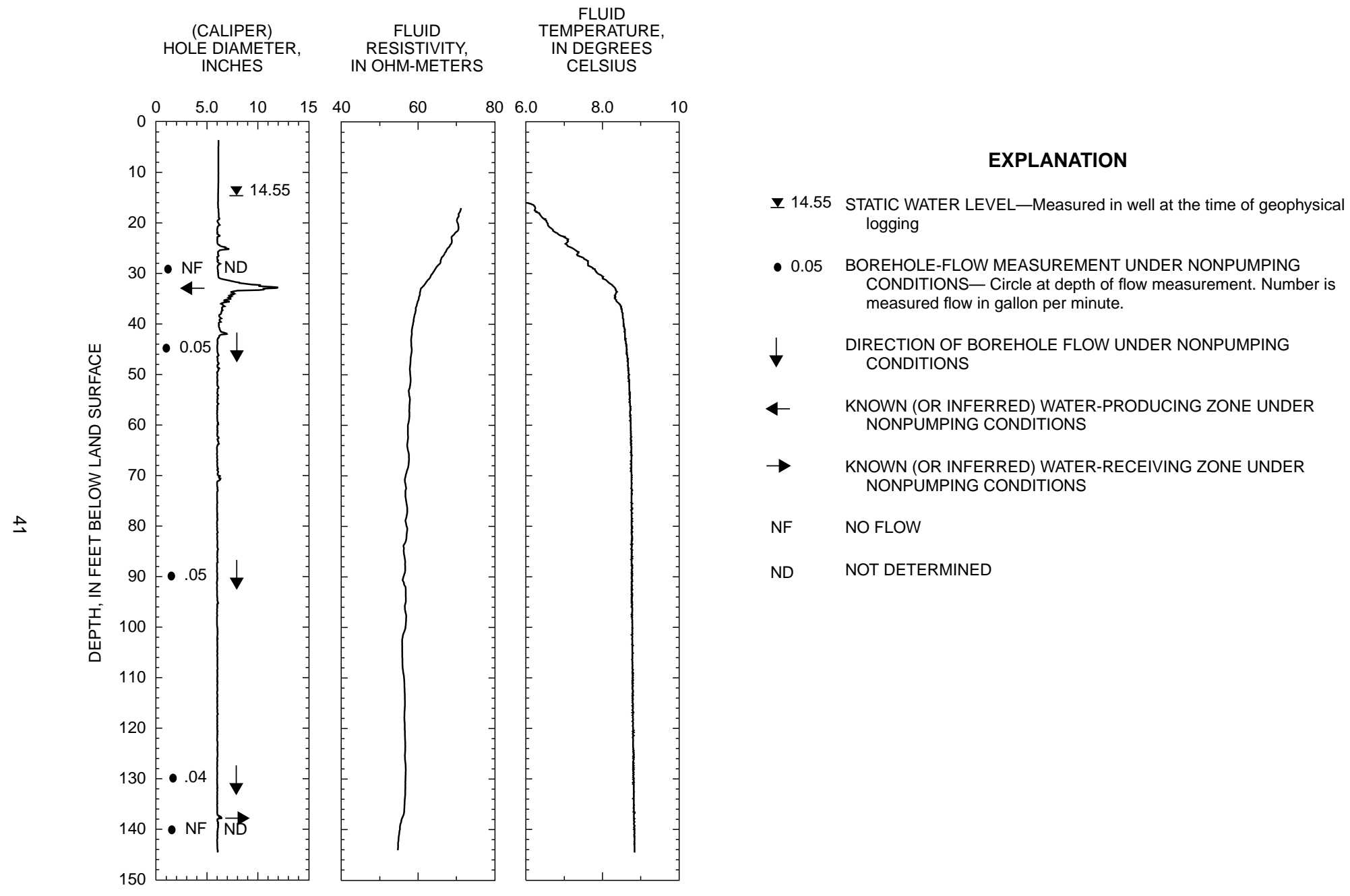

Figure 18. Borehole geophysical logs and direction of borehole flow under nonpumping conditions within MO-647 (R4), collected on March 6, 1996, Butz Landfill Superfund Site, Jackson Township, Monroe County, Pennsylvania. 


\section{MO-648 (R5)}

Monitor well MO-648 was logged February 28, 1996. The caliper log shows this borehole is drilled to a depth of $240 \mathrm{ft}$ bls and is cased with 6-in.-diameter casing to $19 \mathrm{ft}$ bls (fig. 19). The caliper log shows major fractures at 42 to 44 and 64 to $66 \mathrm{ft}$ bls plus numerous minor fractures throughout the openhole interval. The fluid-resistivity log shows changes in slope at 44 and $154 \mathrm{ft}$ bls that indicate possible waterproducing fractures. The fluid-temperature log also shows a change in slope at $44 \mathrm{ft}$ bls. Under nonpumping conditions, the heatpulse flowmeter measured downward borehole flow at 38 and $50 \mathrm{ft}$ bls and no borehole flow at 90, 130, and $170 \mathrm{ft}$ bls (table 23).

A submersible pump was placed at $14 \mathrm{ft}$ bls and the borehole was pumped at approximately $2.7 \mathrm{gal} / \mathrm{min}$. The water level in the borehole declined $2.35 \mathrm{ft}$ after approximately 1 hour of pumping. Under pumping conditions, the heatpulse-flowmeter data show upward borehole flow at 38 and $50 \mathrm{ft} \mathrm{bls,}$ minor upward flow at $70 \mathrm{ft}$ bls, and no flow at $90 \mathrm{ft}$ bls (table 23). The suite of geophysical logs and heatpulse-flowmeter data indicate the fractures at 43 to 45 and 64 to $66 \mathrm{ft}$ bls are the major waterproducing fractures in the borehole; a minor amount of water is produced from the fractures at about 18 and 83 to $86 \mathrm{ft}$ bls.

Table 23. Summary of heatpulse-flowmeter measurements for borehole MO-648 (R5) on February 28, 1996, at the Butz Landfill Superfund Site, Jackson Township, Monroe County, Pennsylvania

[-, not determined]

\begin{tabular}{|c|c|c|c|c|}
\hline $\begin{array}{c}\text { Depth } \\
\text { (feet below land } \\
\text { surface) }\end{array}$ & $\begin{array}{l}\text { Flow rate under } \\
\text { nonpumping } \\
\text { conditions } \\
\text { (gallon per minute) }\end{array}$ & $\begin{array}{l}\text { Flow direction under } \\
\text { nonpumping } \\
\text { conditions }\end{array}$ & $\begin{array}{l}\text { Flow rate under } \\
\text { pumping conditions } \\
\text { (gallon per minute) }\end{array}$ & $\begin{array}{l}\text { Flow direction under } \\
\text { pumping conditions }\end{array}$ \\
\hline 38 & 0.02 & Down & 0.31 & Up \\
\hline 50 & .14 & Down & .16 & Up \\
\hline 70 & - & - & .02 & Up \\
\hline 90 & No flow & - & No flow & - \\
\hline 130 & No flow & - & - & - \\
\hline 170 & No flow & - & - & - \\
\hline
\end{tabular}




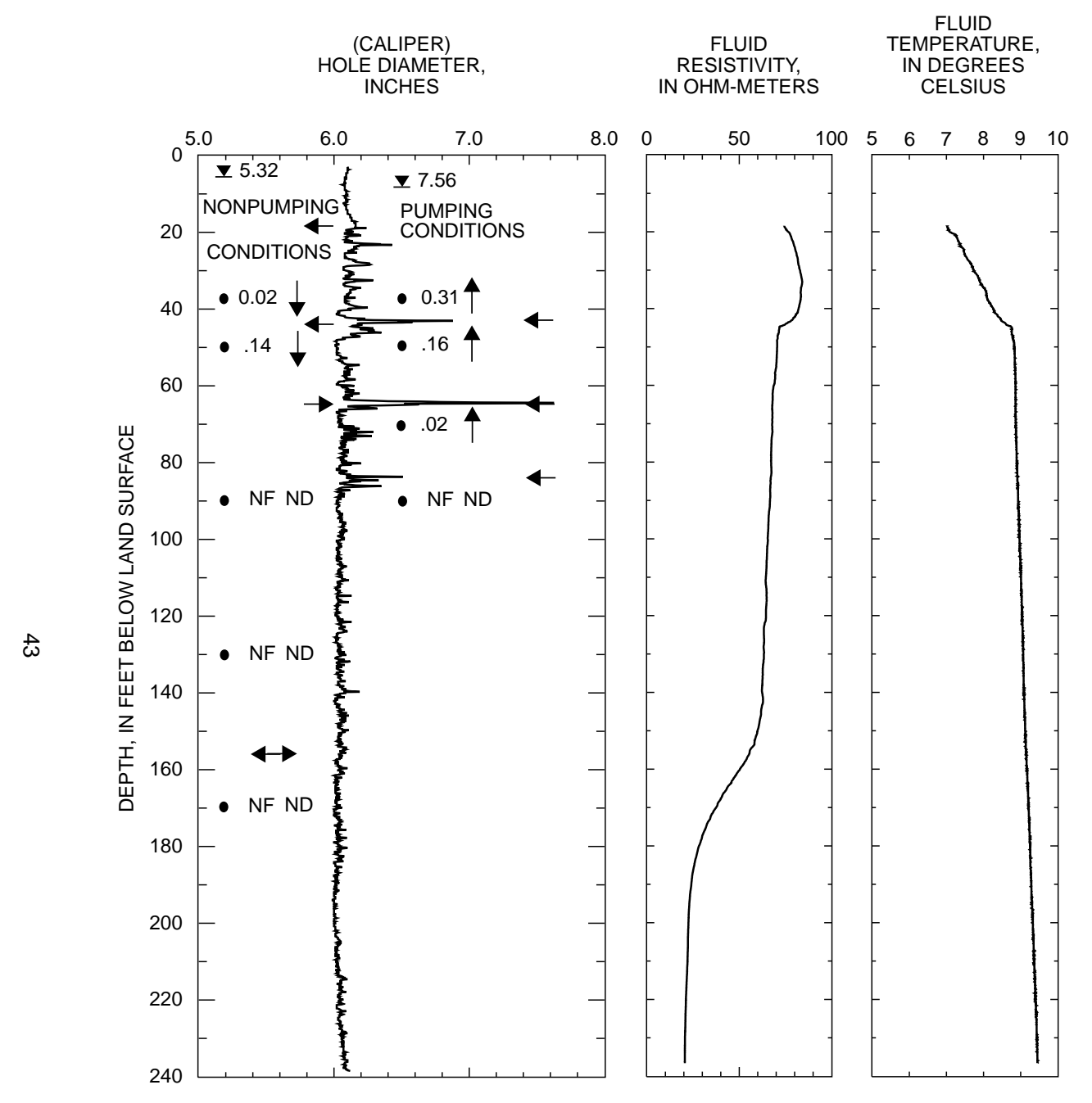

\section{EXPLANATION}

7.32 STATIC WATER LEVEL-Measured in well at the time of geophysical logging

- 0.02 BOREHOLE-FLOW MEASUREMENT UNDER NONPUMPING AND PUMPING CONDITIONS- Circle at depth of flow measurement. Number is measured flow in gallon per minute.

$\uparrow \downarrow$ DIRECTION OF BOREHOLE FLOW UNDER NONPUMPING AND PUMPING CONDITIONS

$4 \quad$ KNOWN WATER-PRODUCING ZONE UNDER NONPUMPING AND PUMPING CONDITIONS

$\rightarrow \quad$ KNOWN WATER-RECEIVING ZONE UNDER NONPUMPING CONDITIONS

$\leftrightarrow \quad$ LATERAL FLOW (INFERRED)

NF NO FLOW

ND NOT DETERMINED

Figure 19. Borehole geophysical logs and direction of borehole flow under nonpumping and pumping conditions within MO-648 (R5), collected on February 28, 1996, Butz Landfill Superfund Site, Jackson Township, Monroe County, Pennsylvania. 


\section{MO-649 (R6)}

Monitor well MO-649 was logged March 5, 1996. The caliper log shows this borehole is drilled to a depth of $241 \mathrm{ft}$ bls and is cased with 6-in.-diameter casing to $18 \mathrm{ft}$ bls (fig. 20). The caliper log shows minor fractures at 34, 89 to $93,114,124$, and $207 \mathrm{ft}$ bls plus numerous smaller fractures throughout the openhole interval. The fluid-resistivity log shows changes in slope at 39 to 44,52 , and $73 \mathrm{ft}$ bls that indicate possible water-producing fractures. The fluid-temperature log and the fluid-resistivity log below $76 \mathrm{ft}$ bls show a constant change with depth, indicating no borehole flow. Under nonpumping conditions, the heatpulse flowmeter measured no borehole flow at 30,60, and $100 \mathrm{ft}$ bls (table 24).

A submersible pump was placed at $21 \mathrm{ft}$ bls, and the borehole was pumped at a rate less than $0.5 \mathrm{gal} / \mathrm{min}$. The water level in the borehole declined $8.83 \mathrm{ft}$ after 52 minutes of pumping and never completely stabilized. Under pumping conditions, the heatpulse-flowmeter data show upward borehole flow at 30 and $35 \mathrm{ft} \mathrm{bls} \mathrm{and} \mathrm{no} \mathrm{flow} \mathrm{at} 60$ and $100 \mathrm{ft}$ bls (table 24). The suite of geophysical logs and heatpulse-flowmeter data indicate the fractures at 39 to $58 \mathrm{ft}$ bls probably are the major water-producing fractures in the borehole.

Table 24. Summary of heatpulse-flowmeter measurements for borehole MO-649 (R6) on March 5, 1996, at the Butz Landfill Superfund Site, Jackson Township, Monroe County, Pennsylvania

$[-$, not determined]

\begin{tabular}{ccccc}
\hline $\begin{array}{c}\text { Depth } \\
\text { (feet below land } \\
\text { surface) }\end{array}$ & $\begin{array}{c}\text { Flow rate under } \\
\text { nonpumping } \\
\text { conditions } \\
\text { (gallons per minute) }\end{array}$ & $\begin{array}{c}\text { Flow direction under } \\
\text { nonpumping } \\
\text { conditions }\end{array}$ & $\begin{array}{c}\text { Flow rate under } \\
\text { pumping conditions } \\
\text { (gallon per minute) }\end{array}$ & $\begin{array}{c}\text { Flow direction under } \\
\text { pumping conditions }\end{array}$ \\
\hline 30 & No flow & - & 0.03 & Up \\
35 & - & - & No flow & Up \\
60 & No flow & - & No flow & - \\
\hline
\end{tabular}




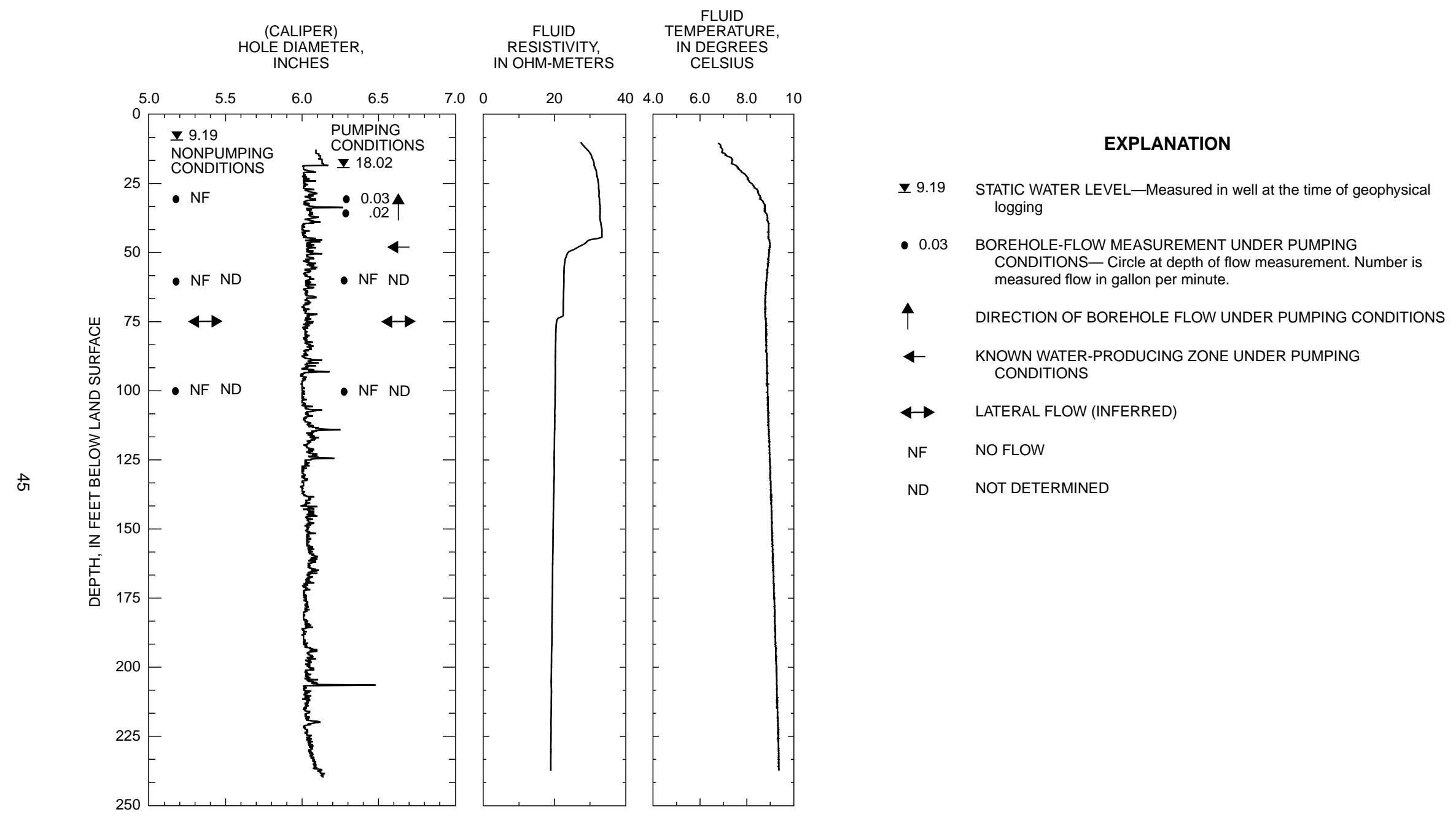

Figure 20. Borehole geophysical logs and direction of borehole flow under nonpumping and pumping conditions within MO-649 (R6), collected on March 5, 1996, Butz Landfill Superfund Site, Jackson Township, Monroe County, Pennsylvania. 


\section{MO-651 (PW-A)}

Monitor well MO-651 was logged July 8, 1996. The caliper log shows this borehole is drilled to a depth of $158.5 \mathrm{ft}$ bls and is cased with 6-in.-diameter casing to $34 \mathrm{ft}$ bls (fig. 21). The caliper log shows encrustation on the casing from 26 to $34 \mathrm{ft}$ bls and a minor fracture at $100 \mathrm{ft}$ bls plus numerous smaller fractures throughout the openhole interval. The natural-gamma log shows minor changes in lithology. The single-point resistance log indicates a water-producing zone at $78 \mathrm{ft}$ bls that correlates to a high-angle fracture and possible water-receiving zones at 55, 87, 100, 116, and $135 \mathrm{ft}$ bls that correlate to changes in lithology and may represent bedding-plane fractures. The fluid-resistivity and fluid-temperature logs show a change in slope at approximately $38 \mathrm{ft}$ bls that correlates to a small fracture on the caliper log. The fluid-temperature log also shows a change in slope at $151 \mathrm{ft}$ bls. Under nonpumping conditions, the heatpulse flowmeter measured downward borehole flow at 20, 29, 46, 64, 82, 94, 120, and $142 \mathrm{ft}$ bls and upward flow at $154 \mathrm{ft}$ bls (table 25). The downward flow measured inside casing at 20 and $29 \mathrm{ft}$ bls is derived from water in the overburden leaking through poorly connected, threaded-casing joints. The suite of geophysical logs and heatpulse-flowmeter data indicate, under nonpumping conditions, most water enters the borehole through a break in the casing, a small fracture at $38 \mathrm{ft} \mathrm{bls,} \mathrm{and} \mathrm{below} 154 \mathrm{ft} \mathrm{bls}$. Most water exits the borehole through the small fracture at $150 \mathrm{ft}$ bls.

A submersible pump was placed at $24 \mathrm{ft}$ bls, and the borehole was pumped at approximately $1.1 \mathrm{gal} / \mathrm{min}$. The water level in the borehole declined $9.60 \mathrm{ft}$ after 35 minutes before stabilizing. Under pumping conditions, the heatpulse flowmeter measured upward borehole flow at 46, 64, 82, 94, 120, and $142 \mathrm{ft}$ bls and no flow at $154 \mathrm{ft}$ bls (table 25). The fractures at 100 and $150 \mathrm{ft}$ bls produce the greatest amount of water.

Table 25. Summary of heatpulse-flowmeter measurements for borehole MO-651 (PW-A) on July 8, 1996, at the Butz Landfill Superfund Site, Jackson Township, Monroe County, Pennsylvania

\begin{tabular}{|c|c|c|c|c|}
\hline $\begin{array}{c}\text { Depth } \\
\text { (feet below land } \\
\text { surface) }\end{array}$ & $\begin{array}{l}\text { Flow rate under } \\
\text { nonpumping } \\
\text { conditions } \\
\text { (gallon per minute) }\end{array}$ & $\begin{array}{l}\text { Flow direction under } \\
\text { nonpumping } \\
\text { conditions }\end{array}$ & $\begin{array}{l}\text { Flow rate under } \\
\text { pumping conditions } \\
\text { (gallons per minute) }\end{array}$ & $\begin{array}{l}\text { Flow direction under } \\
\text { pumping conditions }\end{array}$ \\
\hline 20 & 0.21 & Down & - & - \\
\hline 29 & .47 & Down & - & - \\
\hline 46 & .66 & Down & 0.81 & $\mathrm{Up}$ \\
\hline 64 & .63 & Down & 1.1 & $\mathrm{Up}$ \\
\hline 82 & .66 & Down & 1.1 & $\mathrm{Up}$ \\
\hline 94 & .63 & Down & 1.1 & $\mathrm{Up}$ \\
\hline 120 & .52 & Down & .86 & $\mathrm{Up}$ \\
\hline 142 & .45 & Down & .63 & $\mathrm{Up}$ \\
\hline 154 & .17 & $\mathrm{Up}$ & No flow & - \\
\hline
\end{tabular}




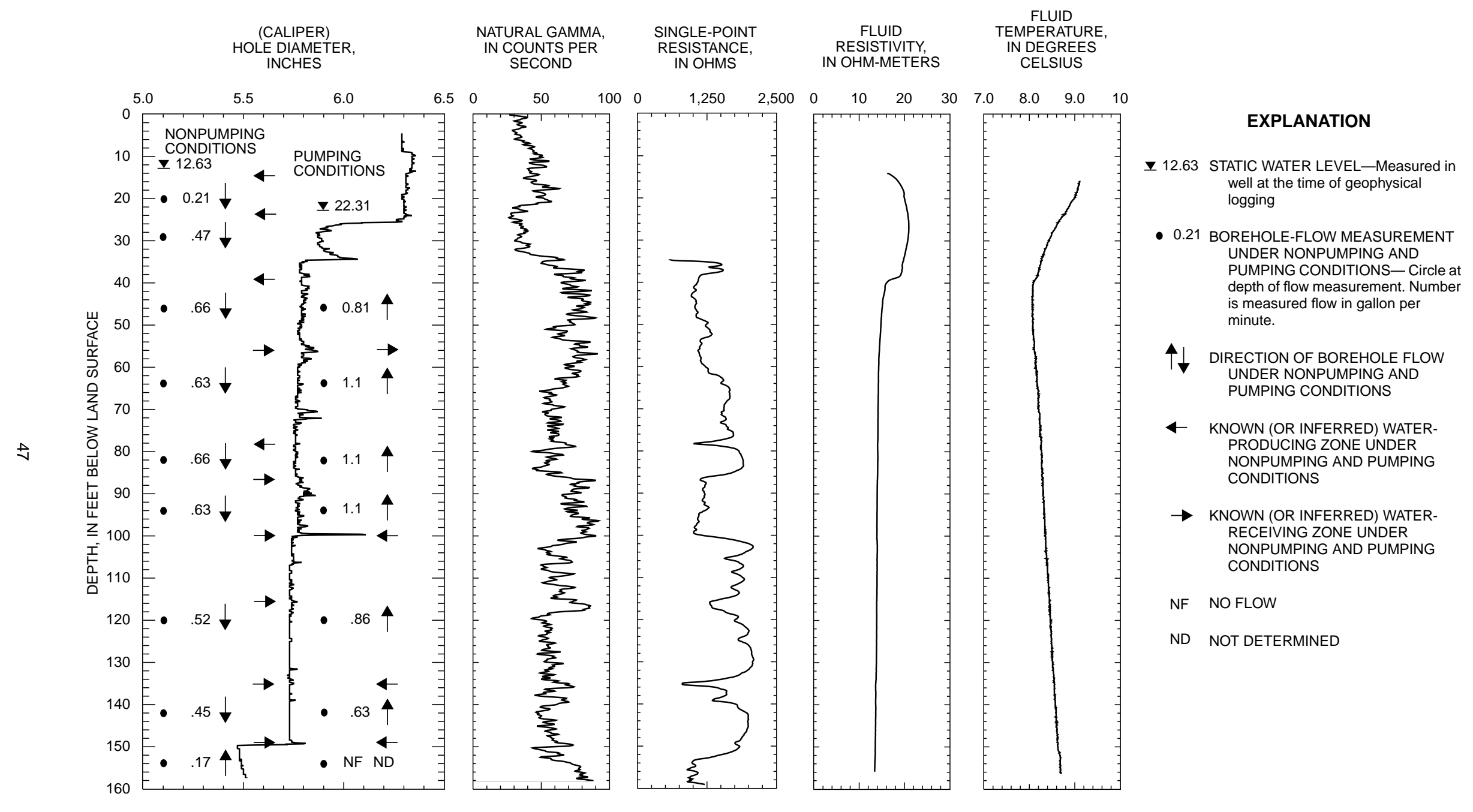

Figure 21. Borehole geophysical logs and direction of borehole flow under nonpumping and pumping conditions within MO-651 (PW-A), collected on July 8 , 1996, Butz Landfill Superfund Site, Jackson Township, Monroe County, Pennsylvania. 


\section{MO-652 (PW-B)}

Monitor well MO-652 was logged July 9, 1996. The caliper log shows this borehole is drilled to a depth of $149 \mathrm{ft}$ bls and is cased with 6-in.-diameter casing to $37 \mathrm{ft} \mathrm{bls}$ (fig. 22). The caliper log shows encrustation on the casing from 30 to $37 \mathrm{ft}$ bls, a major fracture at $140 \mathrm{ft}$ bls plus numerous minor fractures throughout the openhole interval, and a change in drill bit diameter at $88 \mathrm{ft}$ bls. The natural-gamma log shows minor variations in lithology. The single-point resistance log indicates possible water-producing or water-receiving zones at 48, 65, 85, 97, and $112 \mathrm{ft}$ bls that correlate to minor fractures on the caliper $\log$ and at $140 \mathrm{ft}$ bls that correlates to a major fracture. The fluid-resistivity and fluid-temperature logs show a change in slope at approximately $50 \mathrm{ft}$ bls that correlates to a minor fracture on the caliper log. Under nonpumping conditions, the heatpulse flowmeter measured downward borehole flow at 56, 82, 104, 128, and $142 \mathrm{ft}$ bls and no flow at $43 \mathrm{ft}$ bls (table 26). The suite of geophysical logs and heatpulse-flowmeter data indicate water enters the borehole through fractures at 48 to 50 and $98 \mathrm{ft}$ bls and moves downward. Water exits the borehole through fractures at 144 to $145 \mathrm{ft}$ bls.

A submersible pump was placed at $40 \mathrm{ft}$ bls, and the borehole was pumped at approximately $0.75 \mathrm{gal} / \mathrm{min}$. The water level in the borehole declined $0.40 \mathrm{ft}$ after 42 minutes before stabilizing. Under pumping conditions, the heatpulse flowmeter measured upward borehole flow at 56, 82, 104, 128, and $142 \mathrm{ft}$ bls (table 26). The fracture at 144 to $145 \mathrm{ft}$ bls produce the greatest amount of water.

Table 26. Summary of heatpulse-flowmeter measurements for borehole MO-652 (PW-B) on July 9, 1996, at the Butz Landfill Superfund Site, Jackson Township, Monroe County, Pennsylvania

$[-$, not determined]

\begin{tabular}{ccccc}
\hline $\begin{array}{c}\text { Depth } \\
\text { (feet below land } \\
\text { surface) }\end{array}$ & $\begin{array}{c}\text { Flow rate under } \\
\text { nonpumping } \\
\text { conditions } \\
\text { (gallon per minute) }\end{array}$ & $\begin{array}{c}\text { Flow direction under } \\
\text { nonpumping } \\
\text { conditions }\end{array}$ & $\begin{array}{c}\text { Flow rate under } \\
\text { pumping conditions } \\
\text { (gallons per minute) }\end{array}$ & $\begin{array}{c}\text { Flow direction under } \\
\text { pumping conditions }\end{array}$ \\
\hline 43 & No flow & - & - & - \\
56 & 0.35 to 0.62 & Down & 0.95 & Up \\
82 & .35 & Down & 1.2 & Up \\
104 & .42 & Down & 1.2 & Up \\
128 & .46 & Down & 1.1 & Up \\
\hline
\end{tabular}




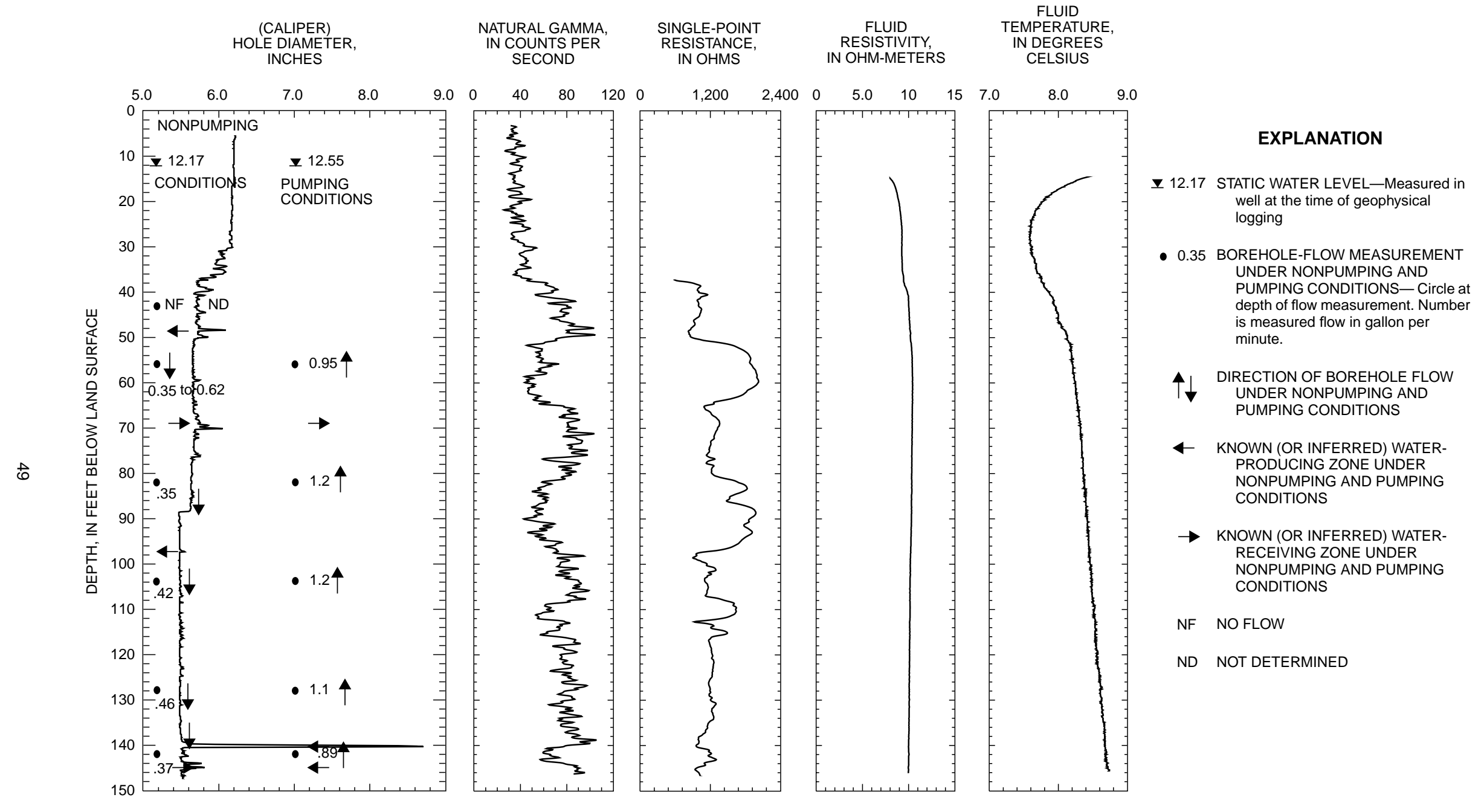

Figure 22. Borehole geophysical logs and direction of borehole flow under nonpumping and pumping conditions within MO-652 (PW-B), collected on July 9, 1996 , Butz Landfill Superfund Site, Jackson Township, Monroe County, Pennsylvania. 


\section{MO-653 (PW-C)}

Monitor well MO-653 was logged August 20, 1996. The caliper log shows this borehole is drilled to a depth of $185.5 \mathrm{ft}$ bls and is cased with 6-in.-diameter casing to $29 \mathrm{ft}$ bls (fig. 23). The caliper log shows encrustation on the casing from 17 to $29 \mathrm{ft}$ bls, major fractures at 30 and 32 to 34, and minor fractures from 44 to $49,87,89,128,134$, and $177 \mathrm{ft}$ bls plus numerous smaller fractures throughout the openhole interval. The caliper, natural-gamma, and single-point resistance logs indicate possible water-producing zones at 100 and $120 \mathrm{ft}$ bls that probably are bedding-plane fractures. The fluid-resistivity log shows a change in slope at 34, 52, 68, 80, and $110 \mathrm{ft}$ bls. The fluid-temperature log shows a change in slope at 31, 45, 52, and $178 \mathrm{ft}$ bls. Under nonpumping conditions, the heatpulse-flowmeter measured downward borehole flow at $40,60,80,110,148$, and $172 \mathrm{ft}$ bls and no flow at $180 \mathrm{ft}$ bls (table 27). The suite of geophysical logs and heatpulse-flowmeter data indicate, under nonpumping conditions, water enters the borehole through fractures at 30 to 34 and 40 to $52 \mathrm{ft}$ bls and moves downward; most of the water exits the borehole through the fracture at $178 \mathrm{ft}$ bls.

A submersible pump was placed at $35 \mathrm{ft}$ bls, and the borehole was pumped at approximately $2 \mathrm{gal} / \mathrm{min}$. The water level in the borehole declined $3.22 \mathrm{ft}$ after 49 minutes and never completely stabilized. Under pumping conditions, the heatpulse-flowmeter measured upward borehole flow at 40, 60, 80, 110, 148, and $172 \mathrm{ft}$ bls and no flow at $180 \mathrm{ft}$ bls (table 27). The suite of geophysical logs and heatpulseflowmeter data indicate, under pumping conditions, the fractures at 64,100,120, and $178 \mathrm{ft}$ bls become water-producing zones. The fractures from 40 to $52 \mathrm{ft}$ bls become water-receiving zones.

Table 27. Summary of heatpulse-flowmeter measurements for borehole MO-653 (PW-C) on August 20, 1996, at the Butz Landfill Superfund Site, Jackson Township, Monroe County, Pennsylvania

[-, not determined]

\begin{tabular}{ccccc}
\hline $\begin{array}{c}\text { Depth } \\
\text { (feet below land } \\
\text { surface) }\end{array}$ & $\begin{array}{c}\text { Flow rate under } \\
\text { nonpumping } \\
\text { conditions } \\
\text { (gallons per minute) }\end{array}$ & $\begin{array}{c}\text { Flow direction under } \\
\text { nonpumping } \\
\text { conditions }\end{array}$ & $\begin{array}{c}\text { Flow rate under } \\
\text { pumping conditions } \\
\text { (gallon per minute) }\end{array}$ & $\begin{array}{c}\text { Flow direction under } \\
\text { pumping conditions }\end{array}$ \\
\hline 40 & 0.78 & Down & 0.28 & Up \\
60 & 1.4 & Down & .52 & Up \\
80 & 1.5 & Down & .46 & Up \\
110 & 1.4 & Down & .37 & Up \\
148 & 1.5 & Down & .24 & Up \\
172 & 1.2 & Down & No flow & - \\
\hline
\end{tabular}



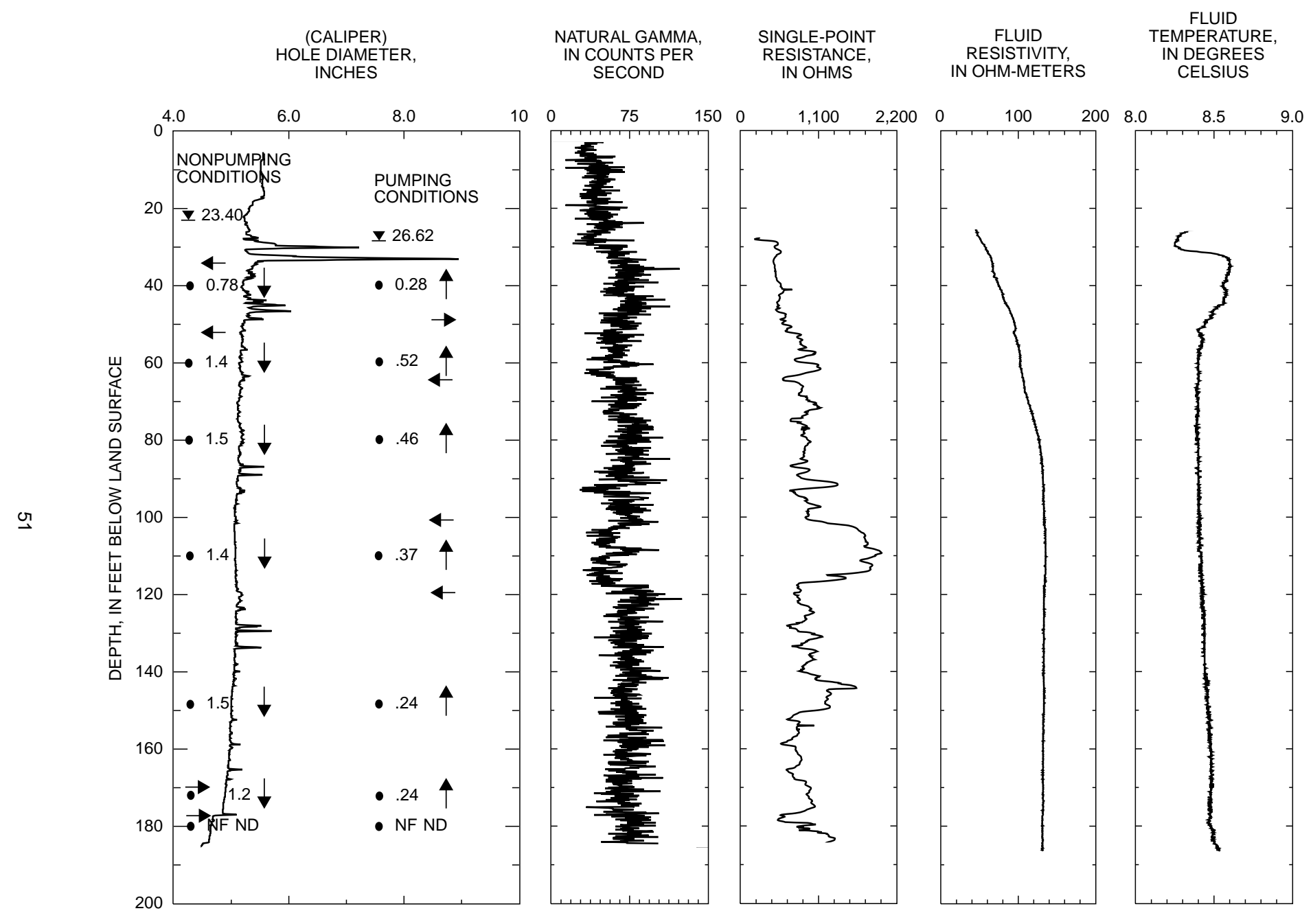

SECOND IN OHMS IN OHM-METERS CELSIUS

EXPLANATION

23.40 STATIC WATER LEVEL-Measured in well at the time of geophysical logging

- 0.78 BOREHOLE-FLOW MEASUREMENT UNDER NONPUMPING AND PUMPING CONDITIONS- Circle at depth of flow measurement. Number is measured flow in gallon per minute.

$\uparrow \downarrow$ DIRECTION OF BOREHOLE FLOW UNDER NONPUMPING AND PUMPING CONDITIONS

$4 \quad$ KNOWN (OR INFERRED) WATERPRODUCING ZONE UNDER NONPUMPING AND PUMPING CONDITIONS

$\rightarrow$ KNOWN (OR INFERRED) WATERRECEIVING ZONE UNDER RECEIVING ZONE UNDER
NONPUMPING AND PUMPING CONDITIONS

NF NO FLOW

ND NOT DETERMINED

Figure 23. Borehole geophysical logs and direction of borehole flow under nonpumping and pumping conditions within MO-653 (PW-C), collected on August 20, 1996 , Butz Landfill Superfund Site, Jackson Township, Monroe County, Pennsylvania. 


\section{MO-654 (PW-D)}

Monitor well MO-654 was logged July 1, 1996. The caliper log shows this borehole is drilled to a depth of $248 \mathrm{ft}$ bls and is cased with 6-in.-diameter casing to $30 \mathrm{ft}$ bls (fig. 24). The caliper log shows a major fracture at $42 \mathrm{ft}$ bls plus numerous minor fractures throughout the openhole interval. The naturalgamma log shows only minor variation in lithology except at 68 to 70, 203 to 205, and 206 to $208 \mathrm{ft}$ bls where more silty or shaley lenses are present. The fluid-resistivity and fluid-temperature logs show changes in slope at 48 and $100 \mathrm{ft}$ bls. Under nonpumping conditions, the heatpulse flowmeter measured upward borehole flow at 38, 200, 215, and $238 \mathrm{ft}$ bls and no flow at 50, 81, 116, 150, and $170 \mathrm{ft}$ bls (table 28). Flow rates, however, varied during logging and probably were affected by the drilling of monitor well MO-651, indicating the two wells are hydraulically connected. The suite of geophysical logs and heatpulse-flowmeter data indicate, under nonpumping conditions, a small quantity of water enters the borehole at about $44 \mathrm{ft}$ bls, moves upward, and exits the borehole at the fracture just below the casing. The greatest amount of water enters the borehole below $238 \mathrm{ft}$ bls, moves upward, and exits the borehole through the fractures between 170 and $200 \mathrm{ft}$ bls. There may be some lateral flow at about $95 \mathrm{ft} \mathrm{bls}$.

A submersible pump was placed at $40 \mathrm{ft}$ bls, and the borehole was pumped at a rate of less than $0.5 \mathrm{gal} / \mathrm{min}$. The pumping rate was periodically decreased in an effort to stabilize drawdown. The water level in the borehole declined $9.24 \mathrm{ft}$ after 48 minutes of pumping before stabilizing. Under pumping conditions, the heatpulse flowmeter measured upward borehole flow at 52, 81, 116, 150, and $225 \mathrm{ft}$ bls and no borehole flow at 200 and $238 \mathrm{ft}$ bls (table 28). The suite of geophysical logs and heatpulse-flowmeter data indicate, under pumping conditions, the fractures at 161 to 163,238 , and possibly $95 \mathrm{ft}$ bls are waterproducing zones.

Table 28. Summary of heatpulse-flowmeter measurements for borehole MO-654 (PW-D), July 1, 1996, at the Butz Landfill Superfund Site, Jackson Township, Monroe County, Pennsylvania

$[-$, not determined]

\begin{tabular}{ccccc}
\hline $\begin{array}{c}\text { Depth } \\
\text { (feet below land } \\
\text { surface) }\end{array}$ & $\begin{array}{c}\text { Flow rate under } \\
\text { nonpumping } \\
\text { conditions } \\
\text { (gallon per minute) }\end{array}$ & $\begin{array}{c}\text { Flow direction under } \\
\text { nonpumping } \\
\text { conditions }\end{array}$ & $\begin{array}{c}\text { Flow rate under } \\
\text { pumping conditions } \\
\text { (gallon per minute) }\end{array}$ & $\begin{array}{c}\text { Flow direction under } \\
\text { pumping conditions }\end{array}$ \\
\hline 38 & 0.07 & Up & - & - \\
50 & No flow & - & - & - \\
52 & - & - & 0.16 & Up \\
81 & No flow & - & .23 & Up \\
116 & No flow & - & .18 & Up \\
150 & No flow & - & .22 & - \\
170 & No flow & - & - & - \\
200 & .07 & Up & No flow & - \\
215 & .16 & Up & - & Up \\
225 & - & - & .06 & - \\
238 & .18 & Up & No flow & - \\
\hline
\end{tabular}



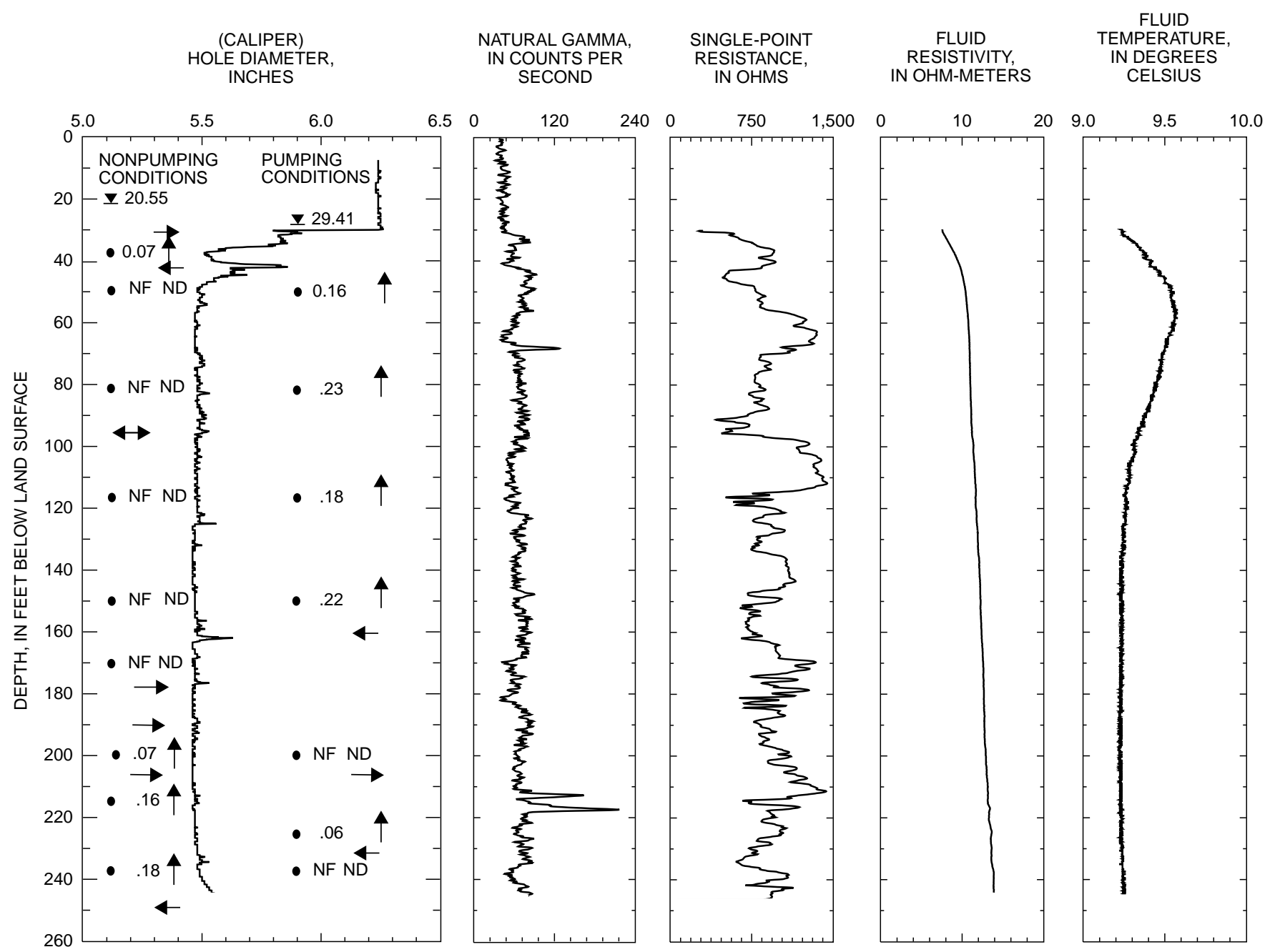

\section{EXPLANATION}

又 20.55 STATIC WATER LEVEL-Measured in well at the time of geophysical logging

- 0.07 BOREHOLE-FLOW MEASUREMENT UNDER NONPUMPING AND PUMPING CONDITIONS- Circle a depth of flow measurement. Number is measured flow in gallon per minute.

$\uparrow$ DIRECTION OF BOREHOLE FLOW UNDER NONPUMPING AND PUMPING CONDITIONS

$4 \quad$ KNOWN (OR INFERRED) WATERPRODUCING ZONE UNDER NONPUMPING AND PUMPING CONDITIONS

$\rightarrow$ KNOWN (OR INFERRED) WATERRECEIVING ZONE UNDER NONPUMPING AND PUMPING CONDITIONS

$\leftrightarrow$ LATERAL FLOW (INFERRED)

NF NO FLOW

ND NOT DETERMINED

Figure 24. Borehole geophysical logs and direction of borehole flow under nonpumping and pumping conditions within MO-654 (PW-D), collected on July 1, 1996 , Butz Landfill Superfund Site, Jackson Township, Monroe County, Pennsylvania. 


\section{MO-685 (R7)}

Monitor well MO-685 was logged November 6, 2000. The caliper log shows this borehole is drilled to a depth of $248 \mathrm{ft}$ bls and is cased with 5.25-in.-diameter casing to $37 \mathrm{ft}$ bls (fig. 25). The caliper log shows major fractures at 42 to $46 \mathrm{ft}$ bls plus numerous small and minor fractures throughout the open-borehole interval. The natural-gamma log shows only minor variation in lithology. The single-point resistance log indicates possible water-producing zones at 44, 46, 105, 112 to 114, 188, and $190 \mathrm{ft}$ bls. The fluid-resistivity $\log$ shows minor deflections in slope at 48, 145, 163, and $213 \mathrm{ft}$ bls. The fluid-temperature log shows minor deflections in slope at 167,214 , and $226 \mathrm{ft}$ bls. Under nonpumping conditions, the heatpulse flowmeter indicated turbulent flow at 50, 78, and $212 \mathrm{ft} \mathrm{bls,} \mathrm{no} \mathrm{flow} \mathrm{at} \mathrm{150,} \mathrm{178,} \mathrm{and} 232 \mathrm{ft}$ bls, and inconsistent flow measurements at $106 \mathrm{ft}$ bls (table 29). The suite of geophysical logs and heatpulse-flowmeter data indicate, under nonpumping conditions, lateral flow is dominant and no flow below the minor fracture at $227 \mathrm{ft} b l s$.

Table 29. Summary of heatpulse-flowmeter measurements for borehole MO-685 (R7) on November 6, 2000, at the Butz Landfill Superfund Site, Jackson Township, Monroe County, Pennsylvania

$[-$, not determined]

\begin{tabular}{ccc}
\hline $\begin{array}{c}\text { Depth } \\
\text { (feet below land } \\
\text { surface) }\end{array}$ & $\begin{array}{c}\text { Flow rate under } \\
\text { nonpumping } \\
\text { conditions } \\
\text { (gallons per minute) }\end{array}$ & $\begin{array}{c}\text { Flow direction under } \\
\text { nonpumping } \\
\text { conditions } \\
\text { (gallons per minute) }\end{array}$ \\
\hline 50 & Turbulent & - \\
78 & Turbulent & - \\
106 & Inconsistent & - \\
150 & No flow & - \\
178 & No flow & - \\
212 & Turbulent & - \\
232 & No flow & \\
\hline
\end{tabular}



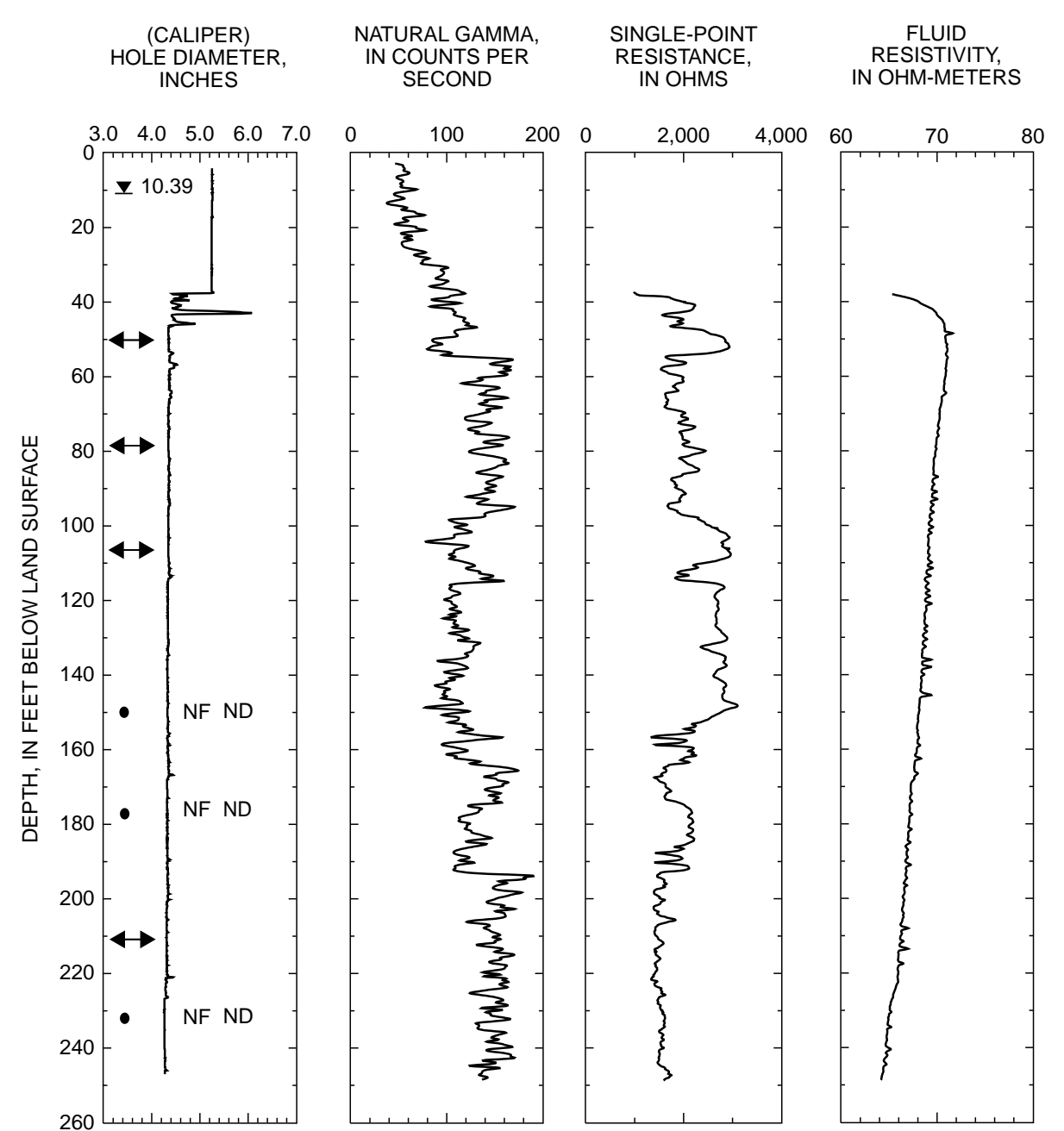
FLUID
TEMPERATURE
IN DEGREES
CELSIUS

SECOND IN OHMS

IN OHM-METERS

\section{EXPLANATION}
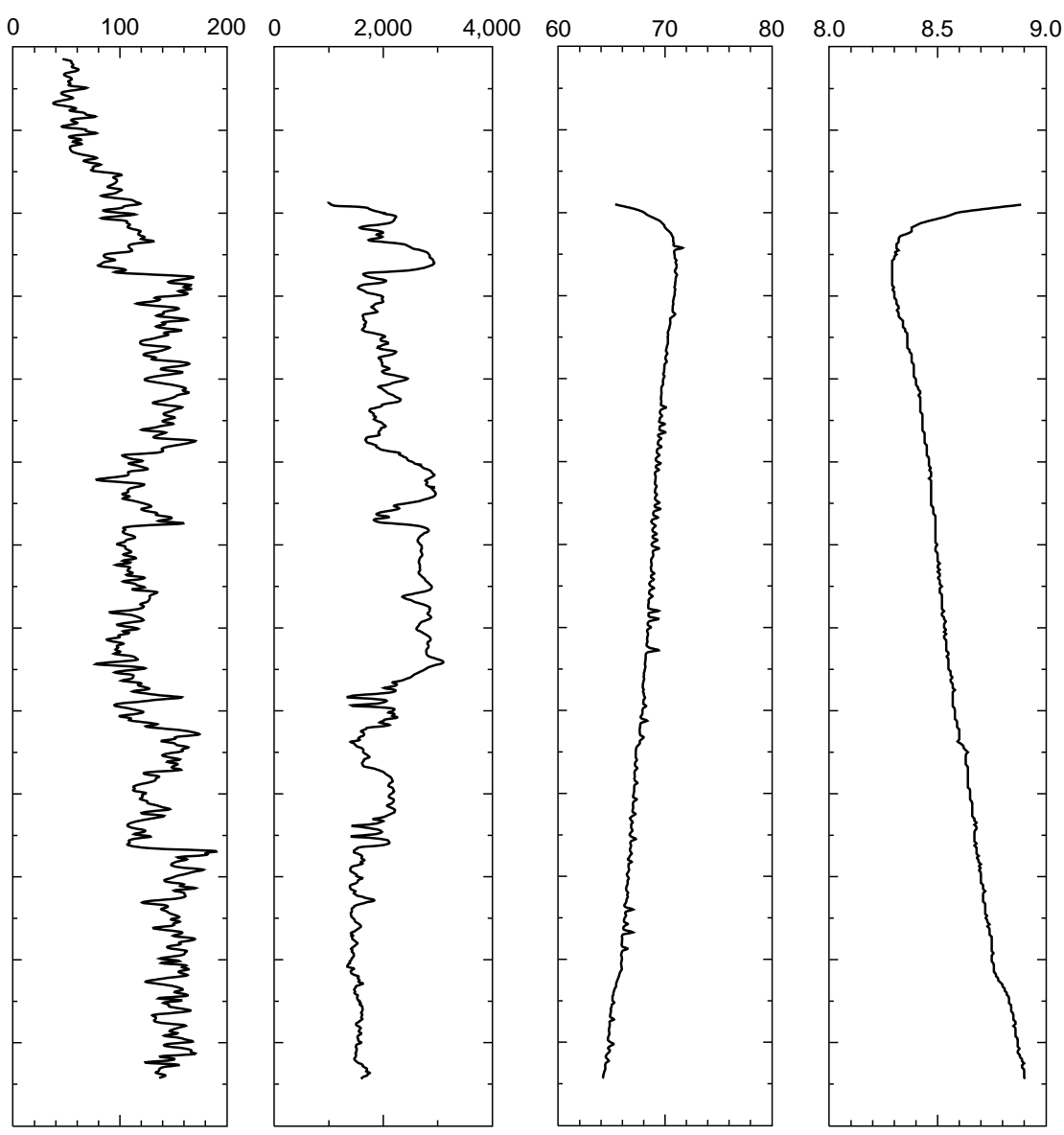

7 10.39 STATIC WATER LEVEL-Measured in well at the time of geophysical logging

- BOREHOLE-FLOW MEASUREMENT UNDER NONPUMPING CONDITIONS- Circle at depth of flow measurement.

$\leftrightarrow$ LATERAL FLOW (INFERRED)

NF NO FLOW

ND NOT DETERMINED

Figure 25. Borehole geophysical logs and direction of borehole flow under nonpumping conditions within MO- 685 (R7), collected on November 6, 2000, Butz Landfill Superfund Site, Jackson Township, Monroe County, Pennsylvania. 


\section{MO-686 (R8)}

Monitor well MO-686 was logged October 24, 2000. The caliper log shows this borehole is drilled to a depth of $249 \mathrm{ft}$ bls and is cased with 5.25-in.-diameter casing to $38 \mathrm{ft}$ bls (fig. 26). The caliper log shows several minor fractures at 85 to 90, 119 to 121,129 to 130, 137 to 139, 179, and $193 \mathrm{ft}$ bls plus numerous smaller fractures throughout the open-borehole interval. The natural-gamma log shows only minor variation in lithology. The single-point resistance log indicates possible water-producing or waterreceiving zones at 59, 70, 85 to $87,179,188,222$, and $229 \mathrm{ft}$ bls. The fluid-resistivity log shows a major deflection in slope at $40 \mathrm{ft}$ bls and numerous minor deflections from 72 to $172 \mathrm{ft}$ bls and again at $235 \mathrm{ft}$ bls. The fluid-temperature log shows major changes in slope at 40 and $194 \mathrm{ft}$ bls that correlate to minor fractures on the caliper log. Under nonpumping conditions, the heatpulse flowmeter measured downward flow at 50, 78, 114, 142, 170, and $188 \mathrm{ft}$ bls and no flow at 204 and $226 \mathrm{ft}$ bls (table 30). The suite of geophysical logs and heatpulse-flowmeter data indicate, under nonpumping conditions, most of the water enters the borehole at $40 \mathrm{ft}$ bls; additional water enters the borehole at about 59 and $70 \mathrm{ft}$ bls. The water moves downward with most of the water exiting the borehole through fractures at 179 and $193 \mathrm{ft}$ bls. Some lateral flow may be present from 85 to $87 \mathrm{ft}$ bls.

Table 30. Summary of heatpulse-flowmeter measurements for borehole MO-686 (R8) on October 24, 2000, at the Butz Landfill Superfund Site, Jackson Township, Monroe County, Pennsylvania

$[-$, not determined]

\begin{tabular}{ccc}
\hline $\begin{array}{c}\text { Depth } \\
\text { (feet below land } \\
\text { surface) }\end{array}$ & $\begin{array}{c}\text { Flow rate under } \\
\text { nonpumping } \\
\text { conditions } \\
\text { (gallons per minute) }\end{array}$ & $\begin{array}{c}\text { Flow direction under } \\
\text { nonpumping } \\
\text { conditions }\end{array}$ \\
\hline 50 & 1.1 & Down \\
78 & 1.4 & Down \\
114 & 1.4 & Down \\
142 & 1.4 & Down \\
170 & 1.3 & Down \\
188 & 1.0 & Down \\
204 & No flow & - \\
226 & No flow & - \\
\hline
\end{tabular}




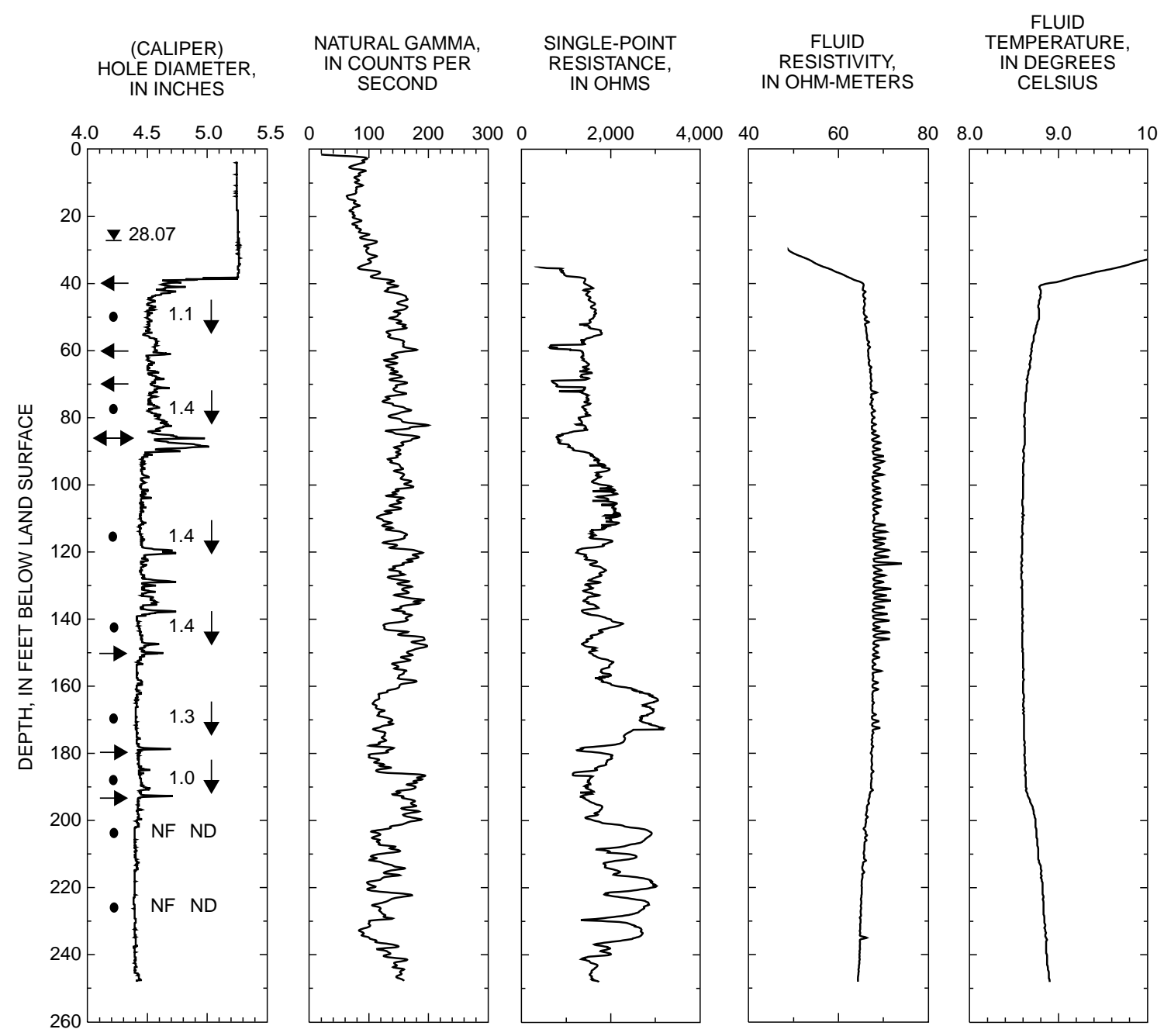

\section{EXPLANATION}

$\mathbf{7} 28.07$ STATIC WATER LEVEL-Measured in well at the time of geophysical logging

- $\quad 1.1$ BOREHOLE-FLOW MEASUREMENT UNDER NONPUMPING

CONDITIONS- Circle at depth of flow measurement. Number is measured flow in gallons per minute.

DIRECTION OF BOREHOLE FLOW UNDER NONPUMPING CONDITIONS

$4 \quad$ KNOWN (OR INFERRED) WATERPRODUCING ZONE UNDER NONPUMPING CONDITIONS

$\rightarrow \quad$ KNOWN (OR INFERRED) WATERRECEIVING ZONE UNDER
NONPUMPING CONDITIONS

$\leftrightarrow$ LATERAL FLOW (INFERRED)

NF NO FLOW

ND NOT DETERMINED

Figure 26. Borehole geophysical logs and direction of borehole flow under nonpumping conditions within MO-686 (R8), collected on October 24, 2000, Butz Landfill Superfund Site, Jackson Township, Monroe County, Pennsylvania. 


\section{MO-687 (R9)}

Monitor well MO-687 was logged November 6, 2000. The caliper log shows this borehole is drilled to a depth of $249 \mathrm{ft}$ bls and is cased with 5.25-in.-diameter casing to $37 \mathrm{ft}$ bls (fig. 27). The caliper log shows a major fracture at $37 \mathrm{ft}$ bls and minor fractures at 116 to $117,188,235$, and 244 to $246 \mathrm{ft}$ bls plus smaller fractures throughout the open-borehole interval. The natural-gamma log shows only minor variation in lithology except at 4 to 6 and 21 to $24 \mathrm{ft}$ bls where more silty or shaley lenses are present. The single-point resistance $\log$ indicates possible water-bearing fractures at 58,82 to $87,95,188$, and 244 to $246 \mathrm{ft}$ bls. The fluid-resistivity log shows a major deflection in slope at $189 \mathrm{ft}$ bls, plus numerous minor deflections from $43,51,57$, and 70 to $189 \mathrm{ft}$ bls. The fluid-temperature log shows a major deflection at $189 \mathrm{ft}$ bls, plus minor deflections at $44,51,57,74$ to 82,116 , and 140 to $172 \mathrm{ft}$ bls. The borehole video camera proved useful from 38 to $56 \mathrm{ft}$ bls where the water was less cloudy. Possible high-angle fractures were seen at 39 and $41 \mathrm{ft}$ bls. Possible low-angle fractures were seen at 43 and $46 \mathrm{ft}$ bls. A lithologic contact was seen at $56 \mathrm{ft}$ bls; the contact dips to the southeast. The interval from 166 to $170 \mathrm{ft}$ bls was somewhat clearer, possibly indicating a water-producing zone. Possible low-angle fractures were seen at 166 and $170 \mathrm{ft}$ bls. Under nonpumping conditions, the heatpulse flowmeter measured downward flow at 68, 99, 160, 220, and $240 \mathrm{ft}$ bls and turbulent flow at 46 and $55 \mathrm{ft}$ bls (table 31). The suite of geophysical logs and heatpulse-flowmeter data indicate, under nonpumping conditions, most water enters the borehole through fractures from 37 to 59 and $189 \mathrm{ft}$ bls, moves downward, and exits the borehole through the major fracture at 244 to $246 \mathrm{ft}$ bls. Additional water enters the borehole through minor fractures at 82 to 87 and $95 \mathrm{ft}$ bls.

Table 31. Summary of heatpulse-flowmeter measurements for borehole MO-687 (R9) on November 6, 2000, at the Butz Landfill Superfund Site, Jackson Township, Monroe County, Pennsylvania [>, greater than; - , not determined]

\begin{tabular}{ccc}
\hline $\begin{array}{c}\text { Depth } \\
\text { (feet below land } \\
\text { surface) }\end{array}$ & $\begin{array}{c}\text { Flow rate under } \\
\text { nonpumping } \\
\text { conditions } \\
\text { (gallons per minute) }\end{array}$ & $\begin{array}{c}\text { Flow direction under } \\
\text { nonpumping } \\
\text { conditions }\end{array}$ \\
\hline 46 & Turbulent & - \\
55 & Turbulent & - \\
68 & $>1.5$ & Down \\
99 & 1.4 & Down \\
160 & 1.3 & Down \\
220 & $>1.5$ & Down \\
240 & $>1.5$ & Down \\
\hline
\end{tabular}




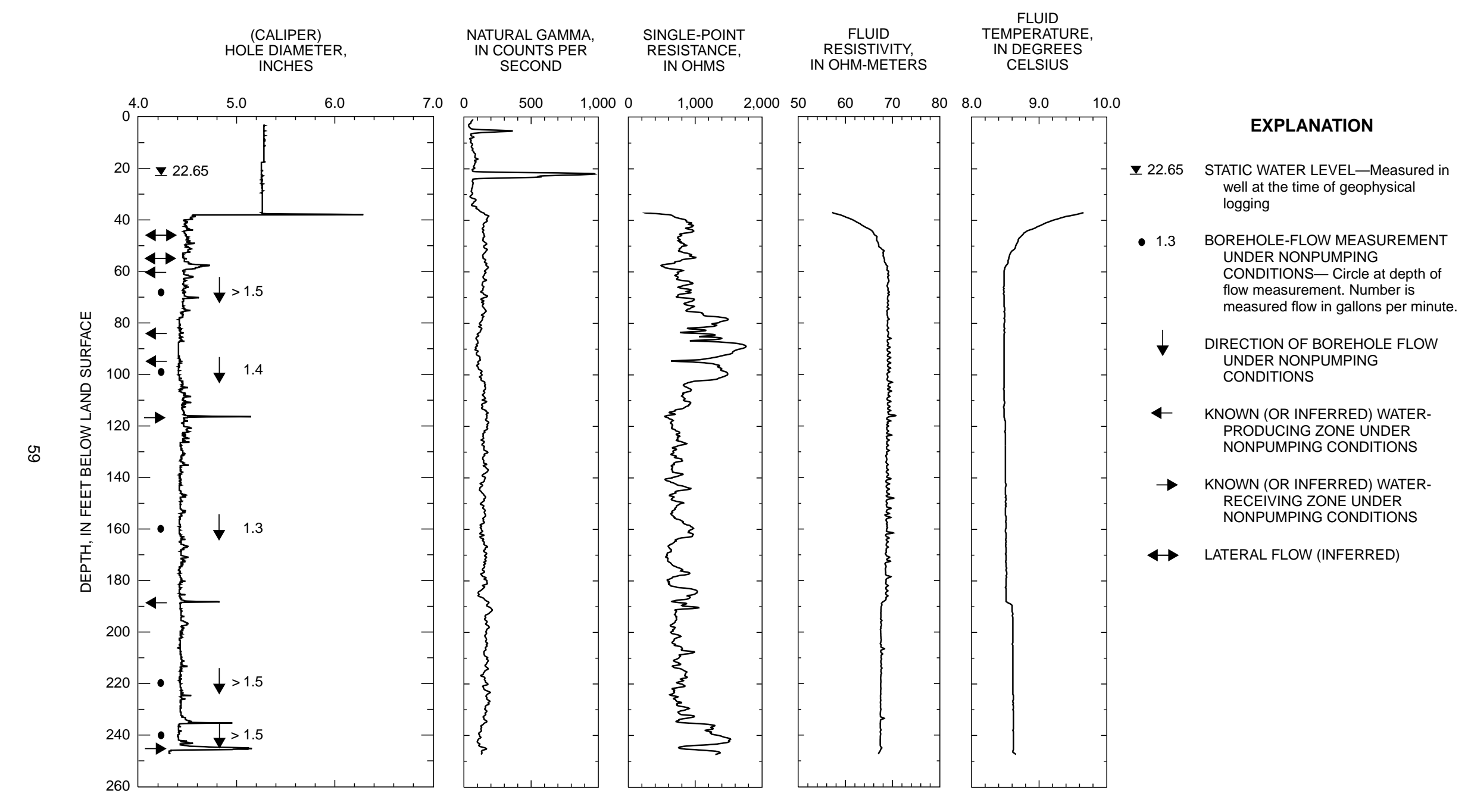

Figure 27. Borehole geophysical logs and direction of borehole flow under nonpumping conditions within MO-687 (R9), collected on November 6, 2000, Butz Landfill Superfund Site, Jackson Township, Monroe County, Pennsylvania. 


\section{MO-688 (R11B)}

Monitor well MO-688 was logged October 24, 2000. The caliper log shows this borehole is drilled to a depth of $140.2 \mathrm{ft}$ bls and is cased with 6.75-in.-diameter casing to $19 \mathrm{ft}$ bls (fig. 28). The caliper log shows minor fractures at 37 and $132 \mathrm{ft}$ bls plus numerous smaller fractures throughout the open-borehole interval. The natural-gamma log shows only minor variation in lithology with less silty layers at 58 to 72 and 113 to $131 \mathrm{ft}$ bls. The single-point resistance log indicates possible water-bearing fractures at 34, 37, and $74 \mathrm{ft}$ bls. The fluid-resistivity log shows scattered but minor deflections in slope from 25 to $82 \mathrm{ft}$ bls and continuous but minor deflections from 84 to $139 \mathrm{ft}$ bls. The fluid-temperature log shows minor deflections in slope at $69 \mathrm{ft}$ bls and from 113 to $139 \mathrm{ft}$ bls. Under nonpumping conditions, the heatpulse flowmeter measured upward flow at 50,70, 80, and $100 \mathrm{ft}$ bls and no flow at 30 and $120 \mathrm{ft}$ bls (table 32). The borehole video camera did not prove useful in well MO-688 because the water was too cloudy for visual identification of borehole flow or other borehole features such as fractures. The suite of geophysical logs and heatpulse-flowmeter data indicate, under nonpumping conditions, most water enters the borehole through a series of small fractures from about 82 to $120 \mathrm{ft}$ bls, moves upward, and exits the borehole through small or minor fractures between 30 and $50 \mathrm{ft}$ bls.

Table 32. Summary of heatpulse-flowmeter measurements for borehole MO-688 (R11B) on October 24, 2000, at the Butz Landfill Superfund Site, Jackson Township, Monroe County, Pennsylvania

\begin{tabular}{|c|c|c|}
\hline $\begin{array}{c}\text { Depth } \\
\text { (feet below land } \\
\text { surface) }\end{array}$ & $\begin{array}{l}\text { Flow rate under } \\
\text { nonpumping } \\
\text { conditions } \\
\text { (gallon per minute) }\end{array}$ & $\begin{array}{l}\text { Flow direction under } \\
\text { nonpumping } \\
\text { conditions }\end{array}$ \\
\hline 30 & No flow & - \\
\hline 50 & 0.1 & Up \\
\hline 70 & 0.1 to 0.2 & $\mathrm{Up}$ \\
\hline 80 & .1 & Up \\
\hline 100 & .1 to .2 & Up \\
\hline 120 & No flow & - \\
\hline
\end{tabular}




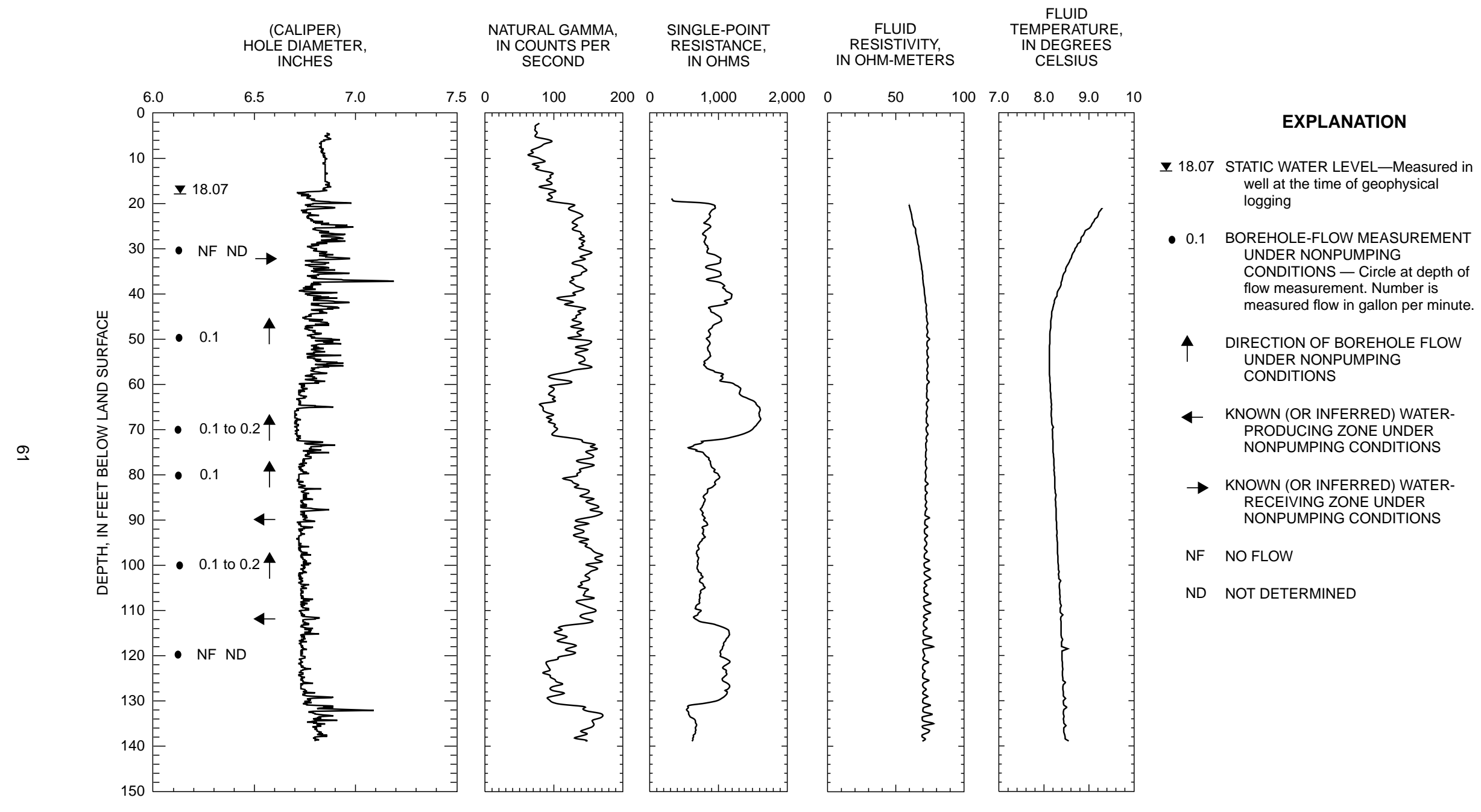

Figure 28. Borehole geophysical logs and direction of borehole flow under nonpumping conditions within MO-688 (R11B), collected on October 24, 2000, Butz Landfill Superfund Site, Jackson Township, Monroe County, Pennsylvania. 


\section{SUMMARY}

Between February 1996 and November 2000, the USGS, in cooperation with USEPA and BOR, collected geophysical logs in 27 open-borehole wells at the Butz Landfill Superfund Site, Jackson Township, Monroe County, Pa., to determine casing depth and depths of water-producing zones, waterreceiving zones, and zones of vertical borehole flow. The site was used as a municipal-waste dump from approximately 1963 to 1969 . Video logs also were conducted in 6 of the 27 open-borehole wells to locate fractures, joints, and weathered zones. The wells range in depth from 57 to $319 \mathrm{ft}$ bls and penetrate the Long Run Member of the Catskill Formation, which consists of series of fluvial fining upward cycles of siltstone, shale, and sandstone units. Water-producing or water-receiving zones were penetrated as shallow as $16 \mathrm{ft}$ bls and as deep as $255 \mathrm{ft}$ bls. Vertical borehole flow was measured in 20 boreholes.

\section{REFERENCES CITED}

Berg, T.M., Barnes, J.H., Sevon, W.D., Skema, V.W., Wilshusen, J.P., and Yannacci, D.W., 1989, Physiographic provinces of Pennsylvania: Pennsylvania Geological Survey, 4th ser., map 13 (color), scale 1:2,000,000, $8.5 \times 11$ inches.

Berg, T.M., Sevon, W.D., and Bucek, M.F., 1977, Geology and mineral resources of the Pocono Pines and Mount Pocono Quadrangles, Monroe County, Pennsylvania: Pennsylvania Geological Survey, 4th ser., Atlas $204 \mathrm{~cd}, 66 \mathrm{p}$.

Bureau of Reclamation, 1994, Interim geology report for geophysical and survey work plan stage II, phase I, Butz Landfill, OU-2, Monroe County, Pennsylvania, volumes 1 and 2.

Carswell, L.D., and Lloyd, O.B., Jr., 1979, Geology and groundwater resources of Monroe County, Pennsylvania: Pennsylvania Geological Survey, 4th ser., Water-Resource Report 47, 61 p.

Conger, R.W., 1996, Borehole geophysical logging for water-resources investigation in Pennsylvania: U.S. Geological Survey Fact Sheet 218-95, 2 p.

Fenneman, N.M., 1938, Physiography of Eastern United States: New York, McGraw-Hill Book Company, Inc., $691 \mathrm{p}$.

Keys, W.S., 1990, Borehole geophysics applied to ground-water investigations: U.S. Geological Survey Techniques of Water-Resources Investigations, book 2, chap. E1, 149 p.

Williams, J.H., and Conger, R.W., 1990, Preliminary delineation of contaminated water-bearing fractures intersected by open-hole bedrock wells: Groundwater Monitoring Review, Fall 1990, p. 118-121. 